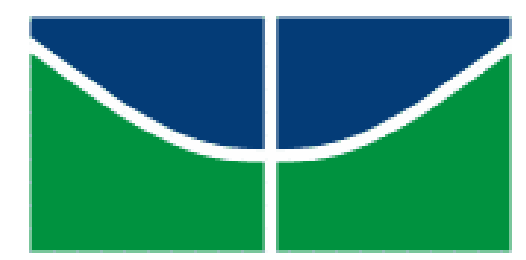

UNIVERSIDADE DE BRASÍLIA

FACULDADE DE EDUCAÇÃO

PROGRAMA DE PÓS-GRADUAÇÃO EM EDUCAÇÃO

MESTRADO EM EDUCAÇÃO

\author{
VALÉRIA ROCHA MELO
}

APERFEIÇOAMENTO DE PROFESSORES PRIMÁRIOS NOS PRIMÓRDIOS DE BRASÍLIA - Contribuições do INEP (1957-1964) 


\section{VALÉRIA ROCHA MELO}

\section{APERFEIÇOAMENTO DE PROFESSORES PRIMÁRIOS NOS PRIMÓRDIOS DE BRASÍLIA- Contribuições do INEP (1957-1964)}

Dissertação apresentada ao Programa de PósGraduação em Educação, da Faculdade de Educação da Universidade de Brasília, como requisito parcial para obtenção do título de Mestre em Educação. Linha de Pesquisa: Profissão Docente, Currículo e Avaliação. Eixo de Interesse: História da profissão docente, das políticas educacionais e das instituições escolares no Brasil.

Orientadora Professora Doutora Eva Waisros Pereira. 


\title{
APERFEIÇOAMENTO DE PROFESSORES PRIMÁRIOS NOS PRIMÓRDIOS DE BRASÍLIA - Contribuições do INEP (1957-1964)
}

\begin{abstract}
Dissertação apresentada ao Programa de PósGraduação em Educação, da Faculdade de Educação da Universidade de Brasília, como requisito parcial para obtenção do título de Mestre em Educação. Linha de Pesquisa: Profissão Docente, Currículo e Avaliação. Eixo de Interesse: História da profissão docente, das políticas educacionais e das instituições escolares no Brasil.
\end{abstract}

Defendida e aprovada em 29 de abril de 2016

Banca Examinadora formada pelos professores:

Prof. ${ }^{\mathrm{a}}$ Dr. ${ }^{\mathrm{a}}$ Eva Waisros Pereira - Presidente

Universidade de Brasília - Faculdade de Educação

Prof. ${ }^{\text {a }}$ Dr. ${ }^{a}$ Benigna Villas Boas - Membro Titular

Universidade de Brasília - Faculdade de Educação

Prof. Dr. Wellington Ferreira de Jesus - Membro Titular

Universidade Católica de Brasília

Prof. Dr. Carlos Alberto Lopes de Sousa - Membro Suplente

Universidade de Brasília - Faculdade de Educação 
Ficha catalográfica elaborada automaticamente,

com os dados fornecidos pelo(a) autor(a)

RM528a

Rocha Melo, Valéria

APERFEIÇOAMENTO DE PROFESSORES PRIMÁRIOS NOS PRIMÓRDIOS DE BRASÍLIA -

Contribuições do INEP (1957 1964) / Valéria Rocha Melo; orientador Eva Waisros

Pereira. -- Brasília, 2016.

$117 \mathrm{p}$.

Dissertação (Mestrado - Mestrado em Educação) -- Universidade de Brasília, 2016 .

1. Qualificação docente. 2. Primórdios de Brasília. 3. História da Educação do Distrito Federal. 4. Instituto Nacional de Estudos Pedagógicos Ansio Teixeira. I. Waisros Pereira, Eva, orient. II. Título. 
Dedico às professoras pioneiras de Brasília, registrando minha admiração pelo esforço, empenho, coragem e sacrifício com que construíram importante legado para a educação da Capital Federal brasileira que merece ser conhecido, respeitado e divulgado.

Ofereço com especial carinho, à memória de minha dileta tia, Olinda Rocha Lôbo, cujos estímulo, apoio e informações foram motivos para empenhar-me no estudo da temática dessa dissertação.

Ao meu pai José Lourenço Neto (in memoriam) que, certamente, estaria muito satisfeito com essa minha conquista. . 


\section{AGRADECIMENTOS}

A Deus pelo dom da vida e pela esperança de ressurreição, em Cristo Jesus.

A professora Eva Waisros Pereira, profunda gratidão por ter desfrutado de sua orientação segura, competente, porém, sempre carinhosa e amável. Sentirei saudades de nossos encontros de orientação.

Aos meus pais, primeira vivência de amor, nos quais me espelho e me re-conheço,

À minha mãe, Sônia, com especial apreço: entusiasta da carreira acadêmica, e que, aos 67 anos realizou o desejo de cursar a faculdade. Mãe querida: há outros horizontes e saberes lhe aguardando.

Ao meu esposo Carlos pela caminhada - nem sempre fácil - do matrimônio, que tem nos proporcionado crescimento. Também pela compreensão pela minha ausência, em virtude dos estudos referentes à esta dissertação.

Aos meus amados filhos: Davi, Laís e Elias, pelo sacrifício exigido em virtude das minhas ausências- muitas vezes de corpo presente- diante das demandas de vocês, nestes dois anos. Eu os amo muito. Por diversos momentos fiquei dividida entre cumprir minhas tarefas acadêmicas ou lhes atender. Penso que esse aprendizado serviu também para nosso crescimento, intelectual, afetivo e familiar. Meu desejo profundo é que sejam muito, muito felizes.

Aos meus irmãos: Marcelo, Ana Cristina e Otílio: Vocês foram minhas primeiras experiências de amor incondicional. Desejo-lhes toda a felicidade do mundo. Às cunhadas Lucélia e Stefany, com carinho. Ao meu cunhado, revendo Carlos Henrique, pelo companheirismo.

Aos meus sobrinhos Júlia, Marcos Paulo, Pedro Henrique, Mariana e Ana Luísa

A professora Maria Alexandra, minha admiração pelo trabalho que desenvolve na Faculdade de Educação e gratidão por ter participado da banca de qualificação do projeto de pesquisa desta dissertação.

A professora Benigna pela honra de sua presença nas bancas de qualificação e defesa dessa dissertação, que, sem dúvida, abrilhantou este trabalho.

Ao professor Wellington, minha gratidão por suas valiosas contribuições por ocasião da banca de defesa dessa dissertação.

Ao professor Carlos Lopes que gentilmente aceitou dar sua contribuição na composição da banca de defesa desse trabalho.

Aos funcionários da Universidade de Brasília, em especial aos da secretaria do Programa de Pós-Graduação em Educação, grata pelo atendimento, sempre pronto e atencioso. 
À Aldriana: amiga de todas as horas, com quem tenho aprendido, também, com o coração.

Ao Justino e Edileusa, casal querido, amigos à toda prova.

À pastora Benta Lima: impossível, com palavras, agradecer seu carinho e cuidado para comigo. Que Deus possa recompensá-la.

Ao Ricardo Praciano, amigo querido, que me salvou diversas vezes nas "panes" tecnológicas. À equipe do grupo de pesquisa do Museu de Educação do Distrito Federal-MUDE; às estagiárias Jade e Raíssa e ao colaborador Raimundo pelo precioso auxílio na busca pelos documentos que se constituíram em informações relevantes para compor esse trabalho.

Aos colegas-amigos da UnB: Alexandra, Adriana, Filipe, Juscelino, Luzeni, Regina e Virgínia: vocês representaram um presente inesperado da vida acadêmica,

À Cláudia Denís, amiga-irmã do coração, a mais de três décadas, nas quais temos compartilhado experiências afetivas, profissionais e espirituais de grande relevância.

Ao Senhor José Oscar, por dividir comigo a preciosa companhia de sua esposa, professora Eva Waisros, para dedicar-se á orientação desta dissertação.

Às tias, tios, primos e primas da grande- Família Oliveira-pelo suporte em tantas áreas, ficaria dificil citar aqui.

Aos colegas da turma da $8^{\text {a }}$ série de 1980, do Colégio do Planalto de Formosa. Esse nosso reconviver está sendo muito agradável, especialmente neste ano de 2016, em que muitos de nós completaremos cinquentenário de vida.

Aos companheiros do Curso de Pedagogia para Professores em Início de Escolarização-PIE, pelas preciosas experiências compartilhadas.

A todos os professores que contribuíram para minha formação. Reconheço a importância de cada um, de cada uma para minha constituição como pessoa e cidadã. Meu carinho especial à vocês.

Aos alunos da Escola Classe 19, que, de forma muito especial, representam em estímulo à minha busca de conhecimento.

A Thaís e Maria Cristina, diretora e vice-diretora da escola Classe 19 de Taguatinga, em que trabalho há vários anos. Minha gratidão pelo apoio incondicional e pela confiança na seriedade deste estudo. Obrigada por me fazerem sentir parte do grupo, mesmo durante a minha ausência. Aos docentes e funcionários da Escola Classe 19 de Taguatinga pelas constantes palavras de ânimo e estímulo.

Agradeço a Secretaria de Educação do Distrito Federal por me proporcionar a licença de afastamento para estudos, sem a qual, acredito, não me seria possível vivenciar essa experiência acadêmica.. 
Agradeço aos professores: Lívia Freitas Borges, Erlando Rêses, Carlos Alberto Lopes , Kátia Píccolo, Kàtia Curado e Cleide Quevêdo Quixadá pelos ensinamentos e reflexões.

À equipe do Arquivo Central do INEP, em especial ao Leonardo, pela atenção e presteza no auxílio ás minhas buscas. Agradeço também à Rita e ao Vanderlei do Arquivo Público do Distrito Federal, pela forma carinhosa que me atenderam.

Agradeço à tia Soêmia por disponibilizar a mim, generosa e liberalmente, o acervo documental deixado pela tia Olinda Rocha Lôbo, professora pioneira, queridíssima, após o seu falecimento. À professora pioneira Elzy Lobo Costa, que mui gentilmente emprestou seus registros, há muito guardados, que foram importantes para a composição dessa pesquisa. Um beijo, como você sempre diz.

A todos os meus familiares, e aos de meu esposo, cujo apoio foi fundamental para a execução dessa dissertação. Impossível nomeá-los, um a um. Recebam meu carinho e sincera gratidão.

À Sandra, por seu carinho e atenção, no trabalho de formatação final dessa dissertação.

Enfim, a todos que, direta ou indiretamente, cooperaram para que esse trabalho fosse possível, minha gratidão. 
A utopia está lá no horizonte.

Me aproximo dois passos, ela se afasta dois

passos.

Caminho dez passos e o horizonte corre dez

passos.

Por mais que eu caminhe, jamais alcançarei.

Para que serve a utopia?

Serve para isso: para que eu não deixe de

caminhar.

(Eduardo Galeano) 


\section{RESUMO}

Esta dissertação versa sobre as estratégias adotadas, no período de fundação de Brasília, no tocante à qualificação de professores do magistério primário e a participação do Instituto Nacional de Estudos e Pesquisas Educacionais Anísio Teixeira nas ações empreendidas. A qualificação do quadro de professores constituía-se premissa básica para efetivar a educação inovadora que se aspirava para a Capital nascente em seus ideais futurísticos. O estudo em questão desenvolveu-se mediante uma pesquisa histórica, com fundamento nos pressupostos teórico-metodológicos da nova história e aporte teórico em autores como Le Goff e Marc Bloch. Para a sua realização, recorreu-se aos seguintes procedimentos metodológicos: pesquisa bibliográfica, análise documental e história oral. As fontes consultadas integram o acervo documental do Instituto Nacional de Estudos e Pesquisas Educacionais Anísio Teixeira - Inep, do Arquivo Público do Distrito Federal e do acervo constituído no âmbito de duas investigações em curso na Faculdade de Educação da Universidade de Brasília, respectivamente intituladas "Educação Básica Pública do Distrito Federal (1956-1964): Origens de um Projeto Inovador" e "Educação Básica no Distrito Federal (1964-1971) Desmonte de um projeto inovador", que incluem entrevistas de professores pioneiros do Distrito Federal. A análise a que se procedeu de documentos diversificados, como relatórios de reuniões pedagógicas, cadernos de anotações, mídia impressa, entrevistas, além de fontes oficiais e legislação de ensino, evidencia que, desde o princípio da constituição do sistema de educação pública na nova Capital do país, houve empenho em se estabelecer políticas voltadas ao aperfeiçoamento profissional dos professores, sob a forma de orientação, cursos, seminários, estágios e outras modalidades de ações formativas, cuja execução esteve, inicialmente, a cargo da Companhia Urbanizadora da Nova Capital - NOVACAP, e, em seguida, foi assumida pela Comissão de Administração do Sistema Educacional de Brasília - CASEB, sob a supervisão direta do Instituto Nacional de Estudos e Pesquisas Educacionais Anísio Teixeira - Inep.

Palavras-chave: Qualificação docente. Primórdios de Brasília. História da Educação do Distrito Federal. Instituto Nacional de Estudos e Pesquisas Educacionais Anísio Teixeira. 


\begin{abstract}
This dissertation talks about the strategies adopted, in the period of the foundation of Brasília, regarding the qualification of teachers in primary teaching and the participation of Instituto Nacional de Estudos e Pesquisas Educacionais Anísio Teixeira on actions taken. The qualification of the teaching staff was the basic premise to carry out innovative education that aspired to the nascent Capital in its futuristic ideals. This research was developed by a historical research, on the basis of theoretical and methodological assumptions of the new history and theoretical framework on authors such as Le Goff (2003) and Marc Bloch (1997). For its realization, we resort to the following methodological procedures: bibliographical research, documentary analysis and oral history. The sources consulted are part of the documentary collection of Instituto Nacional de Estudos e Pesquisas Educacionais Anísio Teixeira (INEP), the Public Archives of the Federal District and the acquis constituted under two ongoing investigations at the Faculty of Education at the University of Brasilia, respectively entitled "Public Basic Education in Federal District (1956-1964): Origins of an innovative project" and "Basic Education in Federal District (1964-1971): Dismantle of an innovative project", including pioneering teacher interviews from the Federal District. It was carried the analysis of diversified documents, such as reports of educational meetings, notebooks, print media, interviews, and official sources and teaching law, shows that, from the beginning of the constitution of the public education system in the new capital of the country, there was commitment to establish policies aimed at professional development of teachers in the form of guidance, courses, seminars, internships and other forms of training activities, whose execution was initially in charge of Companhia Urbanizadora da Nova Capital (NOVACAP), and then it was taken by the Comissão de Administração do Sistema Educacional de Brasília (CASEB), under the direct supervision of Instituto Nacional de Estudos e Pesquisas Educacionais Anísio Teixeira (INEP).
\end{abstract}

Keywords: Teacher qualification. Beginnings of Brasilia. History of Education of Federal District. Instituto Nacional de Estudos Pedagógicos Anísio Teixeira 


\section{LISTA DE TABELAS}

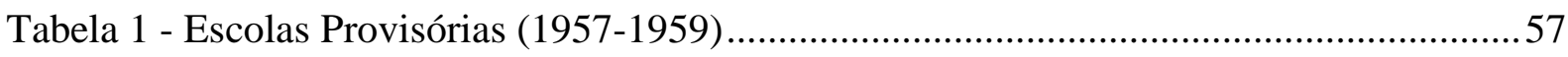

Tabela 1 - Evolução de matrículas no ensino elementar do Distrito Federal...........................63

Tabela 3 - Quantitativo de alunos com 11 anos - por série....................................................... 63

Tabela 4 - Estágios de professores em Salvador/Bahia ........................................................... 70 


\section{LISTA DE QUADROS}

Quadro 1 - Terceiro Estágio realizado na Escola Parque de Salvador/BA- 1960 711

Quadro 2 - Quantitativo de professores do Distrito Federal nos cursos do INEP $(1963 / 1964)$

Quadro 3- Relação Nominal de Professores do Distrito Federal em Cursos do Inep $1963 / 1964$ . .84 .

Quadro 4 - Relação nominal das professoras primárias da NOVACAP - 1959 ..Erro!

\section{Indicador não definido.1}

Quadro 5 - Professores contratados pela Novacap -1957 A 1959. 11112 


\section{LISTA DE ABREVIAÇÕES E SIGLAS}

ANPEd Associação Nacional de Pós-Graduação e Pesquisa em Educação

BDTD Biblioteca Digital Brasileira de Teses e Dissertações

BIA Bloco Inicial de Alfabetização

CALDEME Campanha do Livro Didático e Manuais de Ensino

CASEB Comissão de Administração do Sistema Educacional de Brasília

CILEME Campanha de Inquéritos e Levantamentos do Ensino Médio e Elementar

CBAI Comissão Brasileiro-Americana para o Ensino Industrial

CBPE Centro Brasileiro de Pesquisas Educacionais

CRINEP Centro Regional do Instituto Nacional de Estudos e Pesquisas Educacionais

CRPE Centro Regional de Pesquisa Educacional

DAM Divisão de Aperfeiçoamento do Magistério

DF Distrito Federal

EG Escola Guatemala

HISTEDBR Grupo de Estudos e Pesquisa História, Sociedade e Educação no Brasil

Inep Instituto Nacional de Estudos e Pesquisas Educacionais Anísio Teixeira

JK Presidente Juscelino Kubitschek

MEC Ministério de Educação

Novacap Companhia Urbanizadora da Nova Capital

PABAEE Programa de Assistência Brasileiro-Americana ao Ensino Elementar

PABAES Programa Brasileiro-Americano para o Ensino Secundário

PIE Curso de Pedagogia para Professores em Exercício no Início de Escolarização

Rbep Revista Brasileira de Estudos Pedagógicos

SAPS Serviço de Alimentação da Previdência Social

SEDF Secretaria de Educação do Distrito Federal

Senai Serviço Nacional de Aprendizagem Industrial

SOPP Serviço de Orientação Psicopedagógica

Unesco Organização das Nações Unidas para a Educação, a Ciência e a Cultura

Uniceub Centro Universitário de Brasília

URSS União das Repúblicas Socialistas Soviéticas

USOM-B Missão de Operação - United States Operation Mission - Brazil 


\section{SUMÁRIO}

INTRODUÇÃ

1 TRAJETÓRIA DA PESQUISA .............................................................................22

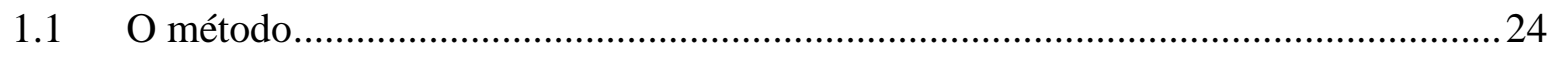

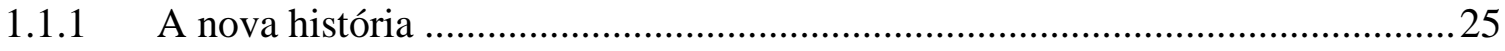

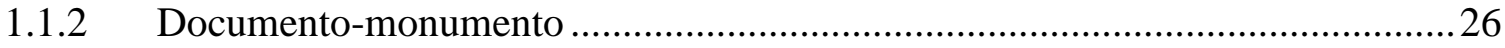

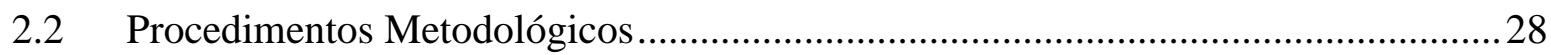

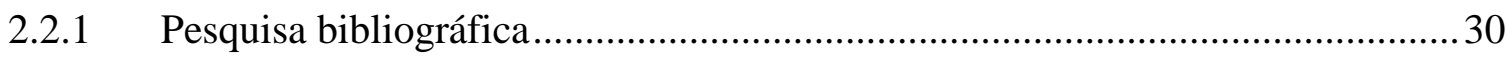

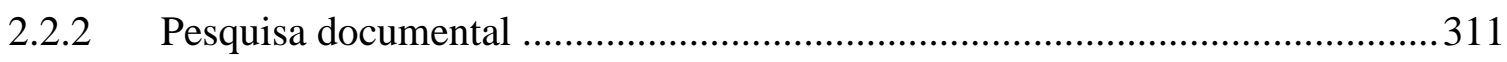

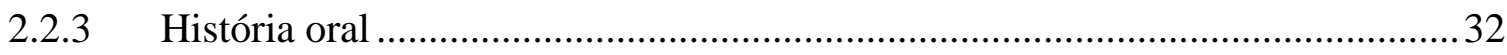

2 POLÍTICAS EM EDUCAÇÃO NO CONTEXTO HISTÓRICO DA FUNDAÇÃO DE

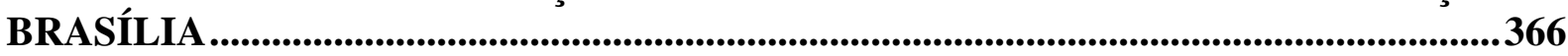

2.2 Processo histórico da formação de professores primários ............................................. 38

2.3 O plano de educação para Brasília ............................................................................. 44

2.4 O Inep e a qualificação de professores no Brasil (1950/1960) ……………………....47

\section{QUALIFICAÇ̃̃O DOS PROFESSORES DO MAGISTÉRIO PRIMÁRIO EM} BRASÍLIA (1957-1964) ..................................................................................................................36

3.1 A primeira escola pública da nova capital — orientação e supervisão do Inep ........61

3.2 Estágio em Salvador: Os professores pioneiros conhecem a Escola Parque da Bahia..

3.3 O Inep e a formação dos quadros técnicos do magistério.............................................76

3.4 A "rede" de formação de professores primários em serviço.......................................... 89

CONSIDERAÇÕES FINAIS...................................................................................99

REFERÊNCIAS ........................................................................Erro! Indicador não definido.2

Anexo A - Relação das primeiras professoras da Escola Júlia Jubitschek...................11111

Anexo B - Professoras contratadas pela Novacap 1957-1959 ...........................................1112

Anexo C - Documento Caseb ......................................................................................................1114 


\section{INTRODUÇÃO}

A presente dissertação resulta de uma pesquisa histórica que versa sobre as estratégias relativas à qualificação profissional dos professores em exercício nas escolas primárias de Brasília, no período de 1957 a 1964, e a participação do Instituto Nacional de Estudos e Pesquisas Educacionais Anísio Teixeira - Inep nas ações empreendidas. O recorte temporal estabelecido para a pesquisa relaciona-se ao período de transferência da capital federal do Rio de Janeiro para o Planalto Central, com a construção e inauguração de Brasília, ocasião em que se deu a concepção e implantação de um plano educacional inovador, e se estende até a ocorrência do golpe militar, (1964-1985) que com seus ditames promove uma ruptura nas políticas na área da educação.

O objeto da pesquisa refere-se à qualificação em serviço de professores primários na nova Capital. A leitura preliminar de documentos a que se teve acesso traz indícios de que o aperfeiçoamento profissional dos primeiros docentes de Brasília deu-se mediante cursos, estágios, seminários, dentre outros eventos promovidos por iniciativa do Inep, então sob a presidência de Anísio Teixeira. A qualificação do magistério, entendida pelo educador como um processo contínuo, teria desdobramentos no âmbito do sistema educacional proposto para a nova Capital.

Estudos históricos atinentes às décadas de 1950 e 1960 adotaram nomenclatura diversa, no que tange à formação em serviço de professores, a exemplo de "formação de professores" e "qualificação, aperfeiçoamento, ou treinamento do magistério" (MENDONÇA, 2008; LIMA, 2008). Nos dias atuais essa é concebida como um processo abrangente, que abarca a formação inicial e a formação continuada, que se estende ao longo de toda a carreira docente. Todavia, em se tratando de períodos anteriores, mais precisamente, décadas de 1950 e 1960, serão empregados os termos utilizados à época, quais sejam, qualificação, aperfeiçoamento ou treinamento do magistério.

O interesse em pesquisar o tema proposto vincula-se à minha trajetória de vida pessoal e profissional ${ }^{1}$, pois, desde tenra infância, vivenciei situações cotidianas de professoras do ensino primário, membros de minha família, ouvi suas histórias sobre a construção de Brasília, e relatos de fatos pitorescos sobre o dia-a-dia da sala de aula, das festas e eventos das escolas. Conforme Bosi (2003) "a memória oral é fecunda quando exerce a função de intermediário cultural entre gerações.” (p.73). As lembranças daquele período remetem a

\footnotetext{
${ }^{1}$ Por se tratar de minha vida pessoal e profissional, utilizarei neste relato os verbos na primeira pessoa do singular.
} 
momentos mágicos que ocorriam em ambiente doméstico, quando elas preparavam materiais didáticos para suas aulas, que me eram apresentados de forma lúdica, mediante jogos e brincadeiras. Essas vivências, permeadas de afetividade, imprimiram marcas profundas na minha história de vida, e vieram posteriormente a aflorar, motivando-me a buscar experiência similar na carreira do magistério.

Dentre as lembranças desse período, destaco especialmente os conhecimentos compartilhados, paulatina e amorosamente, por uma tia, a professora pioneira Olinda Rocha Lôbo, cuja longa e profícua atuação como formadora no sistema público de ensino do Distrito Federal, desde os seus primórdios, constituíram-se em estímulo para a realização deste estudo histórico, que a inclui como uma das protagonistas na qualificação das professoras do ensino elementar da nova Capital.

Nascida em Formosa, Goiás, onde passei a infância e realizei a escolarização básica, sentia-me, desde cedo, motivada a seguir a carreira do magistério. Com esse intuito fiz o curso Normal naquela cidade e, já habilitada, participei de concurso público para professora da Secretaria de Educação do Distrito Federal - SEDF, iniciando, em 1985, o exercício da profissão, na qual permaneço vinculada até os dias atuais. As experiências profissionais nessa instituição foram diversificadas, tendo atuado especialmente como professora de educação infantil e séries iniciais, áreas em que, posteriormente, exerci a função de coordenadora pedagógica, em nível local e na administração central do sistema de ensino.

Em continuidade à minha formação acadêmica, licenciei-me em História, pelo Centro Universitário de Brasília - Uniceub, em 1987, o que me propiciou um olhar investigativo e de aproximação com os fundamentos da nova história ${ }^{2}$, cuja abordagem privilegia, nesta pesquisa, a perspectiva de olhar para o cotidiano, para as mentalidades e para o imaginário, permitindo uma antropologização da história, em contrapartida à visão tradicional de história total. (LE GOFF, 2003).

Importante registrar que, no decorrer da minha atuação profissional, tive oportunidade de dedicar-me a atividades de formação de professores em exercício, participação essa que suscitou em mim ainda maior interesse em investigar a gênese da formação docente no âmbito do Distrito Federal. Cabe especial destaque à experiência que vivenciei, como professora-

\footnotetext{
2 O termo "nova história" será tratado nessa dissertação em letras minúsculas em oposição à tradicional identificação de História como disciplina acadêmica, convencionalmente grafada com inicial em maiúscula. Busca-se dessa forma ser coerente com o pensamento explicitado pelos autores que sustentam as argumentações teóricas dessa pesquisa.
} 
mediadora, no Curso de Pedagogia para Professores em Início de Escolarização - PIE ${ }^{3}$. Esse curso foi concebido pela Faculdade de Educação da Universidade de Brasília - UnB e oferecido aos professores da Secretaria de Estado de Educação do Distrito Federal, por meio de convênio.

Considero o PIE, pela forma em que foi concebido e realizado, a concretização de um dos ideais de Anísio Teixeira quando afirmava que escola e universidades públicas deveriam estar interligadas, em um processo de retroalimentação: a universidade contribuindo com a reflexão teórica e a escola como um laboratório onde esse saber pudesse ser consolidado e investigado, resultando assim na práxis - reflexão sobre o saber colocado em ação.

Caracterizado simultaneamente como um curso de graduação e de formação em serviço, o PIE desenvolveu um programa de estudos consistentes, que intermeava a reflexão teórica à prática docente, buscando consolidar uma práxis fundada nas dimensões ética e política da educação. Essa experiência ampliou a minha compreensão acerca das possibilidades de crescimento profissional dos professores quando lhes é oportunizada uma formação capaz de produzir efetivas mudanças no seu fazer pedagógico, mediante a adoção de uma postura investigativa sobre a sua prática e, sobretudo, de busca de suportes teóricos que possam contribuir para o seu aprimoramento permanente.

Outra vivência importante no trabalho do PIE diz respeito à minha participação em atividades que me permitiram dialogar com os discentes sobre suas memórias de experiências formativas anteriores, como alunos. Ao longo do trabalho pedagógico desenvolvido nas diferentes áreas do conhecimento, constatou-se que os professores tendiam a reproduzir, na docência, práticas que lhes foram introjetadas pelas representações sociais constituídas. Verifica-se, assim, que o docente traz marcas, a ele imperceptíveis, que influenciam o modo de exercer o seu trabalho. O desenvolvimento dessa atividade, no referido curso, teve em vista a tomada de consciência do professor/discente sobre as representações que se materializam em seu cotidiano e a reflexão sobre a propriedade dessas, em sua prática pedagógica.

Cabe destacar ainda que durante a minha estada na Faculdade de Educação - FE/UnB, trabalhando no PIE, tive a oportunidade de estabelecer uma aproximação com o grupo de pesquisa do projeto "Educação básica pública do Distrito Federal (1956-1964): origens de um

\footnotetext{
${ }^{3}$ Esse curso de graduação foi uma parceria entre a Secretaria de Estado e Educação do Distrito Federal (SEEDF) e a Faculdade de Educação (FE) da Universidade de Brasília (UnB), ministrada para os professores da SEEDF. "O curso PIE representa uma alternativa uma alternativa na formação de professores e intenciona superar a relação linear e mecânica entre conhecimento científico-técnico e a prática pedagógica". (Curso PIE Mód. VI vol. 3, 2003, p.11).
} 
projeto inovador", que investiga a história da educação da Capital da República desde os seus primórdios.

O contato com os pesquisadores e com os documentos do acervo constituído por meio da investigação configurou-se como mais uma razão para que eu buscasse, no curso de mestrado da instituição a oportunidade de aprofundar meus conhecimentos e, assim, aventurar-me na realização de uma pesquisa sobre a formação de professores em exercício no sistema público, nos primórdios de Brasília.

Em suma, a minha trajetória profissional levou-me a inquietações sobre o contexto da formação docente no Distrito Federal, remetendo-me ao período de construção de Brasília, e do modelo de educação proposto por Anísio Teixeira. Contexto esse que tem como pano de fundo um panorama marcado pela florescência de ideias e ideais novos, na área de educação, conhecidos apenas por meio de fragmentos ou relatos dos que vivenciaram aquele período histórico. Embora na atualidade existam pesquisa e produção acadêmica a respeito desse tema, constata-se a ausência de estudos focalizando, especificamente, a formação em exercício do magistério primário no aludido período. Daí a necessidade de se investigar e conhecer, de forma aprofundada, os meios e modos em que ocorreu a preparação do professorado, nos primeiros anos da nova Capital, para o desempenho de suas atividades docentes.

Nesse sentido, propôs-se o seguinte problema de pesquisa: Que estratégias foram adotadas para a qualificação de professores do magistério primário para atender ao Plano de Educação proposto no período da fundação de Brasília?

Complementarmente, questões auxiliares permearam a pesquisa:

- Em que consistiu o caráter inovador de educação proposta para a nova Capital?

- Quais eram os requisitos demandados para o ingresso de professores na escola elementar no sistema público de ensino do Distrito Federal em seus primórdios?

- Como foi concebida a qualificação de professores primários na nova Capital?

- Quais foram as contribuições do INEP na qualificação de professores nos primórdios de Brasília?

A partir dessas inquietações, formulou-se como objetivo geral: Identificar as estratégias de qualificação de professores praticada nos primórdios de Brasília (1957-1960). E como objetivos específicos:

- Delinear as características inovadoras da educação proposta para a nova Capital;

- Apontar os requisitos demandados para o ingresso de professores da escola elementar no sistema público de ensino do Distrito Federal em seus primórdios; 
- Delinear a estrutura concebida para a qualificação de professores primários na nova Capital; e,

-Verificar as contribuições relativas à participação do INEP na qualificação dos professores nos primórdios da nova Capital.

Com o propósito de buscar fundamentos teóricos para a presente dissertação empreendeu-se o levantamento de informações nos seguintes sites: Biblioteca Digital Brasileira de Teses e Dissertações - BDTD; Associação Nacional de Pós-Graduação e Pesquisa em Educação - ANPEd e Grupo de Estudos e Pesquisa História, Sociedade e Educação no Brasil-HISTEDBR. Nessa busca foram utilizadas as expressões: história da formação de professores no Distrito Federal e história da formação docente no Brasil.

O levantamento realizado não evidenciou a existência de estudos que tratem do recorte específico desta dissertação, embora tenham sido localizados artigos que guardam aproximação com temática relacionada à educação nos primeiros anos da nova Capital. Esses artigos advêm da produção do grupo da pesquisa intitulada "Educação básica pública do Distrito Federal (1956-1964): origens de um projeto inovador”, que também é responsável pela organização da obra "Nas Asas de Brasília; Memórias de uma utopia educativa (19561964)", de 2011, que representou um dos pilares para a fundamentação desse estudo.

Com referência à formação e profissionalização docente foram localizadas duas dissertações desenvolvidas na FE/UnB, de cunho historiográfico; a primeira (SOUZA, 2010) teve em vista o resgate da história profissional dos professores pioneiros do Distrito Federal, no período de 1957 a 1960, e a segunda (AMARAL, 2014), a reconstrução da história da formação do magistério primário no decorrer dos primeiros anos da Capital Federal, tendo como foco o Curso Normal proposto no Plano de Construções Escolares de Brasília.

$\mathrm{Na}$ conclusão dessas pesquisas, Souza (2010) reporta-se ao sentido e à significação que as professoras deram ao seu próprio trabalho, contextualizado em determinado momento histórico do país, e aponta para os traços de proletarização e de profissionalização docente. Destaca, ainda, a importância do papel do professor pioneiro no momento inicial de formação da sociedade brasiliense e as transformações efetuadas no sistema de educação pública, à época. Amaral (2014) afirma que a experiência de implementação do curso de formação dos professores na Nova Capital foi uma prática inovadora, seja em programas e planos, seja mediante a vivência no cotidiano dos que estiveram envolvidos. Processo esse que afirma ter sido interrompido com a instituição do regime militar, em 1964.

De igual importância é a produção levantada sobre as políticas públicas adotadas para a atualização e qualificação de professores, no contexto nacional e regional, no decorrer 
das décadas de 1950-1960, período em que se insere a pesquisa proposta. Cabe pontuar, todavia, que a produção acadêmica sobre essa temática, no aludido período, ainda é reduzida. Mendonça (2008) atribui tal fato ao apagamento de nossa memória e a interrupção de experiências inovadoras em virtude do golpe militar de 1964.

No site HISTEDBR foram localizados uma dissertação de mestrado e dois artigos. A primeira refere-se a uma pesquisa sobre a Escola Guatemala (MACEDO, 2007), uma experiência pioneira em formação de professores, nos anos de 1950-1960, no âmbito das ações de Anísio Teixeira à frente do Inep. O primeiro artigo versa sobre a relação simbólica entre essa escola e as categorias memória, identidade e projeto (STRANG, BATTINI, NISHIKAWA, 2013) e o outro trata das estratégias centrais utilizadas no período analisado para a qualificação de professores (LUIGLI, 2003).

No site Biblioteca Digital Brasileira de Teses e Dissertações - BDTD foi encontrada apenas uma dissertação (GUIMARÃES, 2008a), que apresenta as contribuições de Anísio Teixeira para melhoria da atuação docente no campo do ensino primário, abrangendo suas ideias, propostas e políticas para a formação do magistério primário brasileiro.

No site da ANPEd foram localizados dois artigos apresentados no Grupo de Trabalho, História da Educação - GT-02, da Associação Nacional de Pós-Graduação e Pesquisa em Educação, que tratam, respectivamente, (a) dos projetos de reforma educacional brasileira das décadas de 1950 e 1960, operacionalizados pelos Centros Regionais de Pesquisa Educacionais - CRPE/Inep, (LUIGLI, 2003); (b) das orientações da Unesco apresentadas nos documentos para a educação na América Latina e Caribe, buscando os significados das diretrizes, orientações e recomendações desse órgão e sua implicação nas políticas educativas e de formação de professores no Brasil no período histórico de 1945 a 1990 (GOMIDE e MIGUEL, 2012).

As duas pesquisas a seguir tratam das ações de aperfeiçoamento do magistério desenvolvidas no âmbito do Centro Brasileiro de Pesquisa Educacional e Centros Regionais de Pesquisa Educacional - CBPE/CRPE/Inep, nas décadas de 1950/1960. A primeira refere-se a uma dissertação que analisa as principais diretrizes e linhas de ação dos cursos de formação continuada para o aperfeiçoamento do magistério oferecidos pelo Inep, por meio das ações da Divisão de Aperfeiçoamento do Magistério - DAM, no período de 1955 a 1964 (LIMA, 2008) e, a segunda, relatada em um artigo, trata dos cursos de Especialistas em Educação para a América Latina, que ocorreram no Brasil e no Chile, a partir de 1958, buscando a generalização e melhoria da educação primária e a qualificação de professores e especialistas em educação na América Latina (FERREIRA, 2011). 
Por meio do levantamento realizado verificou-se a não ocorrência de estudo relativo à qualificação dos professores em Brasília, no período de 1957 a 1964, o que mostrou a originalidade do trabalho em pauta.

A dissertação apresenta-se estruturada em três capítulos.

O Capítulo 1 versa sobre a metodologia da pesquisa e os seus pressupostos teóricometodológicos, bem como o contexto da trajetória da pesquisa. Trata-se de uma investigação fundada na nova história, que se utiliza de procedimentos metodológicos referentes à pesquisa bibliográfica, pesquisa documental e história oral.

O Capítulo 2 apresenta uma abordagem histórica sobre os ideais de educação propostos à escola pública quando da fundação de Brasília, em destaque a contribuição de Anísio Teixeira. Traz ainda, elementos que indicam a implantação de políticas em educação no tocante à qualificação de professores.

O Capítulo 3 apresenta a produção dos dados que permeia a categoria de análise da qualificação de professores do magistério primário, quando do período de construção e inauguração de Brasília.

Em seguida encontram-se as considerações finais nas quais se reflete sobre a operacionalização das estratégias utilizadas para a formação docente nos primórdios de Brasília. 


\section{TRAJETÓRIA DA PESQUISA}

Este Capítulo destina-se aos pressupostos teórico-metodológicos que permeiam a perspectiva da nova história, como ferramenta que ancora a discussão em tela.

Ao definir a metodologia da pesquisa faz-se necessário explicitar, primordialmente, o que se compreende por pesquisa. Acredita-se que essa não se constitui em um ato isolado do indivíduo, posto que o mesmo se encontra inserido em um grupo social e suas escolhas serão motivadas pelos interesses que lhes são inerentes.

Para Chizzotti (2008), ao investigar o mundo à sua volta, o homem também investiga a si próprio, uma vez que dele também é partícipe. Enquanto observa e reflete sobre a problemática da sua pesquisa e as soluções já propostas a este problema, também apresenta novas alternativas para o mesmo, intervindo, assim, no mundo, no intuito de torná-lo mais adequado à sua vida.

Em se tratando de uma pesquisa histórica, como a que fundamenta o presente estudo, há de se apresentar, preliminarmente, o conceito de história. Buscou-se em Le Goff (2008) algumas significações para o termo. A palavra historie procede do grego antigo significando procurar e nas línguas românicas pode ser definida: a) pela busca das ações empreendidas pelos homens que se esforça por se instituir como ciência: a ciência histórica; b) pelo objeto de investigação que os homens empreenderam. Segundo o citado historiador, há ainda uma outra interpretação para o termo história, que é o da narração. Uma narração pode ser baseada nos fatos históricos ou ser uma fábula. Algumas línguas fazem distinção entre essas duas significações do termo, como é o caso do inglês - story e history- (conto e história).

Para além destas definições, convém lembrar que a história já foi considerada como a ciência que estuda o passado. Marc Bloch corrige: a história é a "ciência dos homens" e mais que isso "dos homens no tempo" (BLOCH, 1997, p. 89). Ao historiador importa estudar não apenas o que é próprio do homem, mas também, considerar a sua ação no tempo e, decorrente desta, as modificações impressas na civilização.

Le Goff (2003) pontua, ainda, que a história pode até ser vista como a ciência do passado, desde que se torne objeto de incessante reconstrução. Nesse sentido, o referido autor cita Lucien Febvre, o qual explicita que, "a história recolhe sistematicamente, classificando e agrupando os fatos passados, em função das suas necessidades atuais [...]”. E acrescenta o autor, "Organizar o passado em função do presente: assim se poderia definir a função social da história” (FEBVRE, 1949, apud LE GOFF, 2003, p.26). 
A visão desses historiadores permite depreender-se que a história pode ser considerada ciência que estuda o passado, não o passado visto de modo estanque, e sim numa relação consciente desse passado com o presente, sabendo-se que o olhar, e os pés, do historiador estão fincados no tempo presente.

Ao historiador cabe refazer as experiências vividas por outros sujeitos. Essas experiências são das mais variadas naturezas, e as manifestações traduzidas por essas experiências que são o objeto de estudo do historiador. Vestígios e registros em suas mais diversas formas, como: escritos, objetos, literatura, objetos de arte, fotografia.

A esse respeito, Bloch (1997) afirma que "o passado é, por definição, um dado que coisa alguma pode modificar. Mas o conhecimento do passado é coisa em progresso, que initerruptamente se transforma e se aperfeiçoa" (BLOCH, 1997, p. 109, grifo nosso). Assim, o conhecimento histórico é algo plausível de ser ampliado com as contribuições que outros autores, segundo outro ponto de vista, podem lhe acrescentar. Dessa forma, não se pode afirmar que chegamos à verdade absoluta ou ao ponto final sobre determinado evento ou fato histórico, e sim, que o conhecimento acerca deste chegou até determinado ponto.

$\mathrm{O}$ registro escrito possibilita a transferência de pensamento permitindo mesmo a compreensão da história da civilização, e do próprio homem. Por meio da análise da história é possível perceber as mudanças que ocorreram no homem e em suas relações, e decorrentes disso, na humanidade. No entanto, afirma Bloch (1997), é necessário que haja na essência da sociedade humana "um fundo permanente [...] sem o quê o próprio nome do homem e da sociedade não teriam qualquer significado" (BLOCH, 1997, p. 109).

Ao se dedicar a uma pesquisa, qualquer que seja a linha metodológica escolhida, cabe ao investigador fazer-se a seguinte pergunta inicial: qual é o objeto de sua investigação? Segundo Chizzotti (2008), essa pergunta situa-se no campo da filosofia e é uma questão ontológica, relacionada com "a concepção da realidade que o pesquisador assume e da qual partilha ou, simplesmente, a concepção de mundo do investigador” (p. 25). A escolha do objeto diz muito sobre o pesquisador e sobre suas concepções, crenças, modo de se ver e de se colocar no mundo.

A premissa básica é de que a civilização resulta das relações construídas pelo homem e das múltiplas interpretações acerca dessas relações. Por sua vez, as possíveis interpretações advêm da lente teórica a ser utilizada. 


\subsection{O método}

Em face à natureza desta pesquisa e do caráter histórico de que se reveste, optou-se por realizá-la com base nos pressupostos teórico-metodológicos da nova história, cujo fundamento situa-se no cotidiano dos homens comuns, em contraponto à considerada "grande história", que se passa nos salões reais e nos campos sangrentos de batalha (LE GOFF, 1986, p.76). Enquanto na perspectiva tradicional, a pesquisa histórica estrutura-se a partir de eventos, comemorações e personalidades, essa nova concepção revela-nos, sobretudo, o sentimento de duração, nas comunidades e nos indivíduos, daquilo que muda e do que permanece - a própria percepção da história (LE GOFF, 1986).

As representações que se fazem acerca de determinada circunstância são diferentes conforme as sociedades e a época, pois são baseadas na cultura e na visão de mundo dos sujeitos que vivenciam o acontecimento. Daí, a importância de, ao se contextualizar os fatos, "ter fixado com precisão o momento na curva dos destinos", pois, "nunca um fenômeno histórico se explica plenamente fora do seu momento" (BLOCH, 2008, p. 90 e 94). Importa ressaltar que a nova história é concebida como "uma história-problema e não somente uma história descritiva" (BLOCH, 2008, p. 80). Assim, problematizar, relacionar, estabelecer vínculos é o papel do historiador. Diferentemente da abordagem positivista, para a qual o investigador deve ser neutro e sua ação, quase dispensável, deixando que os fatos falem por si só, a nova concepção requer "uma análise dos sistemas históricos, que contribuem para explicar seu funcionamento" (BLOCH, 2008, p.79). O simples amontoar, ajuntar dados, sem o rigor de uma investigação, não terá valor científico e histórico. Cabe ao historiador fazer desses dados um objeto científico (BLOCH, 2008).

A posição teórica do pesquisador será sempre a lente direcionadora de seu olhar. A escolha do tema e a abordagem definida para conduzir a pesquisa estão atreladas à concepção epistemo-filosófica que adota. Nessa ótica, Meksenas (2002) e Vieira (2002) afirmam que a escolha do método não é arbitrária, ela resulta da relação entre a postura teórica do investigador e o objeto pesquisado, assim como se encontra presente na seleção dos dados. Isso porque a ciência e a pesquisa - tal qual a educação ${ }^{4}$ - não são espaços neutros, mas estão atreladas às convicções e escolhas políticas e éticas, tanto do pesquisador como do educador.

\footnotetext{
${ }^{4}$ Paulo Freire, dentre outros educadores, defende essa premissa ao afirmar que a educação é um ato político, diz respeito às escolhas e posição ideológica dos sujeitos envolvidos, e desta forma, nunca será neutra.
} 
O pesquisador não parte do vácuo ou de um ponto zero, uma vez que se ancora em conhecimentos anteriores, os quais, inegavelmente, estão relacionados à determinada linha teórica que possui pressupostos e pontos em que se amparam seus conhecimentos.

Há de se considerar, ainda, como explicitam Le Goff (2003) e Bloch (1997), que a existência de evidências relativas a determinado período ou tema decorre de uma seleção anterior, daqueles que definiram o que era passível de ser preservado, por imprimir importância àquele sujeito, naquele momento, e quais objetos não mereciam o status de ser conservado. Essa seleção prévia ocorre segundo a subjetividade daquele que a faz. Fosse outro o sujeito, outra poderia ser a escolha do objeto a que se deu o mérito de ser preservado.

A partir dessa premissa, é possível inferir que a história do passado será sempre um conhecimento incompleto, uma vez que nos revela daquilo que queremos conhecer, apenas o que foi preservado. Por essa razão, o passado é uma realidade de difícil apreensão em sua totalidade e nunca será plenamente conhecido. Resta ao pesquisador buscar compreendê-lo por meios de fragmentos. Cabe-lhe a tarefa de proceder à reconstrução do passado por meio de pistas não apagadas, e, então, tentar compreender a realidade que essas pistas representam. A esse respeito, Braudel (1980, p.21) citado por Burke (1991) ilustra, de forma poética, que os eventos, os acontecimentos são como "perturbações superficiais, espumas de ondas que a maré da história carrega em suas fortes espáduas", afirmando que "devemos aprender a desconfiar deles" (p. 48).

\subsubsection{A nova história}

Segundo Le Goff (1986), a história do cotidiano tem início no século XVIII, nomeada por "pequena história", a qual surge como contraponto à "grande história" (p. 73). Seu objeto de estudo eram os homens comuns, que não estavam relacionados na história oficial, nem auxiliavam sua compreensão. $O$ historiador francês cita, na gênese desse novo foco da história, personagens como Heródoto e Voltaire, os quais "tentaram situar o cotidiano no centro da história, mas não conseguiram criar uma verdadeira corrente histórica" (LE GOFF, 1986, p. 74). Assim, o cotidiano viria a ser considerado como constituinte do fato histórico e, sua abordagem, a adquirir a organização e status de corrente histórica somente séculos após a iniciativa desses pensadores, decorrente de movimento que ocorreu nas primeiras décadas do século XX.

Esse movimento tornou-se conhecido como a Escola dos Annales, que teve sua origem na reunião de um grupo de historiadores em torno da revista francesa Annales, criada 
em 1929, em que se questionou o caráter determinista e a pobreza de análise com que se revestia a história convencional, incapaz de perceber as situações históricas em sua complexidade e reduzindo-as a simples jogo de poder entre grandes-homens ou países. Esse movimento teve como principais representantes Bloch e Febvre, dentre outros, e vai dar origem a uma nova forma de se pensar a história, denominada nova história.

\subsubsection{Documento-monumento}

Para a reconstrução histórica do passado é imprescindível ao pesquisador a utilização de fontes, consideradas matéria-prima do processo de investigação (LOPES; GALVÃO, 2001). É do diálogo com as fontes que a pesquisa se desenvolve.

E o que se poderá considerar o termo fonte? A palavra fonte significa origem, surgimento, o que pode dar a falsa impressão de que tem existência em si mesma, que surge de forma espontânea, quando na realidade é o investigador que determina se tal objeto ou outro tipo de documento é uma fonte. Essa definição se dá em função do problema e da possibilidade de se relacionar com as indagações que direcionam a pesquisa. Nesse caso, cabe ao pesquisador selecionar, dentre as diversas fontes elencadas, aquelas que poderão dar sentido às questões que se propõe analisar.

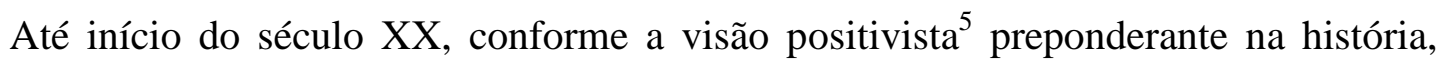
considerava-se fonte, predominantemente, os documentos escritos. Segundo essa concepção, a utilização de documentos escritos era a garantia da objetividade na pesquisa histórica.

Segundo Le Goff (2003), o termo documento, como prova jurídica da forma que o temos ainda hoje, já era usado pelos romanos antes do século XVII. Ao ser adotado como matéria-prima pelos historiadores positivistas, o documento preservou seu sentido de prova, sobretudo ao final do século XIX, quando, com a escola positivista, a história recebe o estatuto de ciência e o documento escrito, sobretudo o oficial, concede à história o sentido de prova científica.

Nessa visão, a habilidade singular do historiador constituía-se em extrair do documento apenas o que ele continha, não lhe acrescentando nada que já não estivesse nele. A característica necessária ao historiador seria a subjetividade, ao qual seria necessário despir-se de qualquer "ideia preconceituosa", assim o documento "falaria por si só" (VIEIRA et al. 2002, p. 14). A esse respeito Le Goff cita Langois e Seignobos os quais afirmam que: "sem

\footnotetext{
${ }^{5}$ Corrente filosófica surgida no início do século XIX que busca explicar as leis do mundo social segundo critérios das ciências exatas e biológicas, cujo precursor é August Comte.
} 
documento não há história” (LANGOIS e SEIGNOBOS apud LE GOFF, 2003, p. 105-106); Le Goff cita, ainda, Febvre que elucida,

[...] A história fez-se, sem dúvida, com documentos escritos. Quando há. Mas pode e deve fazer-se sem documentos escritos, se não existirem [...] Faz-se com tudo o que a engenhosidade do historiador permite utilizar para fabricar o seu mel, quando faltam as flores habituais: com palavras, sinais, paisagens e telhas [...] tudo o que sendo próprio do homem, dele depende, lhe serve, o exprime, torna significante a sua presença, atividade, gostos e maneiras de ser" (LE FEBVRE, apud LE GOFF, 2003, p.107).

Há que se observar que tudo é documento, uma vez que em todas as coisas está imanente o seu caráter histórico. Le Goff (2003) explicita que há dois tipos de materiais aos quais a história, forma científica da memória coletiva, aplica-se. São eles: os documentos e os monumentos. Observa-se que o que é preservado do passado não é o seu conjunto, na íntegra, mas uma seleção feita pelos historiadores. O resultado desta seleção, materiais da memória, pode se caracterizar sob a forma de documentos - escolha do historiador ou monumento herança do passado.

Citando Bloch, Le Goff (2003) indica que a existência de documentos não ocorre ao acaso, mas

[...] dependem de causas humanas que não escapam de forma alguma à análise, e os problemas postos pela sua transmissão, longe de serem apenas exercícios de técnicos, tocam, eles próprios, no mais íntimo da vida do passado, pois o que assim se encontra posto em jogo é nada menos do que a passagem da recordação através de gerações. (BLOCH, 1941 apud LE GOFF, 2003, p. 534).

Le Goff (2003) adverte, ainda "que todo documento é um monumento" e "nunca é puro", ou seja, completamente objetivo (p. 30). O que transforma o documento em monumento é o seu uso pelo poder. Dessa constatação deriva o dever principal do historiador: a crítica ao documento enquanto monumento, pois o documento é fruto da sociedade que o produziu, conforme as relações de forças detentoras do poder. Cabe ao pesquisador efetuar a análise do documento enquanto monumento, desmistificando-o, tendo plena consciência de que este não é inócuo, e sim resultado de uma montagem consciente ou inconsciente de um tempo, da civilização que o construiu, mas também das gerações que se seguiram, que lhe atribuíram o status de ser preservado e perpetuado.

Assim, o documento é monumento enquanto configura o esforço de uma sociedade em impor para o futuro, "voluntária ou involuntariamente", certa imagem de si própria. O 
mencionado historiador francês novamente adverte: salvo exceções, "todo o documento é mentira". Resta ao historiador ter em mente que todo documento é verdadeiro - e, falso.Um monumento é construção, uma montagem. A desmontagem do documento-monumento faz-se por meio da crítica histórica, que busque desvelar os nuances impregnados pelo poder, segundo uma "perspectiva econômica, social, jurídica, política cultural e espiritual” (LE GOFF , 2003, p. 538).

Além das múltiplas perspectivas, acima citadas, o historiador francês, pontua que se deve ainda ter o cuidado de não analisar o documento fora de seu contexto, mas observá-lo no conjunto de monumentos em que se insere. Esse novo documento, ampliado, transformado em dado, “deve ser tratado como um documento/monumento", e, finaliza: "é necessário a construção de um conhecimento que possa alçar o documento/monumento do campo da memória para o campo da ciência histórica” (LE GOFF, 2003, p. 538).

\subsection{Procedimentos Metodológicos}

A escolha dos procedimentos metodológicos de uma pesquisa não se faz ao acaso. $\mathrm{Na}$ verdade, o objeto de estudo é o principal responsável pela determinação dos percursos a serem trilhados na investigação. Ao pesquisador cabe buscar caminhos que, coerentes com sua forma de ver o homem e a humanidade, possam lhe permitir conhecer com maior clareza seu objeto e responder às questões propostas pelo seu estudo.

Assim, na pesquisa histórica em pauta optou-se por utilizar-se da história oral como procedimento metodológico por se considerar que essa, conforme aponta Delgado (2006), é uma elaboração intelectual direcionada para produzir narrativas históricas e "contribui para se evitar o esquecimento e para se registrar múltiplas visões" (DELGADO, 2006, p.50) acerca dos fatos ocorridos.

Essa escolha metodológica também se justifica uma vez que o período de análise dessa pesquisa pode ser considerado como história recente, campo de análise da história oral. Além da história oral, utilizou-se, ainda, os procedimentos metodológicos de pesquisa bibliográfica e pesquisa documental, com a intenção de recompor ou de tecer, qual um tecelão recorre à variedade de fios para compor seu tecido, a realidade da formação em serviço dos professores à época da construção da nlova Capital brasileira, elucidando dessa forma, aspectos ainda pouco conhecidos da história da educação de Brasília.

Conforme entendimento de Delgado (2006), a história oral diz respeito a um indivíduo que se encontra socialmente integrado, por isso seus depoimentos contêm em si um 
"amálgama" de maior amplitude, pois se referem à realidade de uma "comunidade específica" na qual encontra-se inserido (DELGADO, 2006, p. 52).

Nesta pesquisa buscou-se a contribuição dos diferentes atores por meio de relatos de memória relativos ao tempo/espaço investigado. Segundo a citada autora, as possibilidades do estudo da memória são amplas, uma vez que:

[...] as potencialidades da metodologia da história oral, que tem na memória sua principal fonte informativa, são infindáveis, permitindo ao historiador, a seu critério, a adoção de abordagens históricas de características diferentes, com ênfase, por exemplo, no institucional ou no privado, no público ou no particular, na visão individual ou na visão coletiva (DELGADO, 2006, p. $50)$.

Acredita-se que a busca do passado mediante a utilização de relatos de memórias de professores possibilita a reconstituição dos fatos históricos por seus protagonistas e permite responder a uma primeira questão que se colocou ao se propor a pesquisa em tela, qual seja: para que estudar o passado se há tantas inquietações sobre o tempo presente? Porque se interessar em investigar fatos já ocorridos ao invés de tentar compreender o presente e responder às inúmeras indagações que este nos impõe?

Recorrendo ao historiador francês Marc Bloch encontram-se argumentos para justificar a busca de entendimento sobre o passado, uma vez que, para o autor, "a ignorância do passado não se limita a negar a compreensão do presente; e compromete, no presente, a própria ação" (BLOCH, 1997, p. 98). Sabe-se, porém, que não apenas o presente pode ser afetado em virtude do desconhecimento do passado, como também o futuro. A esse respeito, Le Goff (2003) alerta que a percepção e divisão do tempo, e a sua relação entre o antes e o depois não se restringe, tanto em nível individual como coletivo, à contraposição presente/passado. A esses deve se acrescer outra dimensão, ou seja, o futuro. $\mathrm{O}$ autor recorre à explicação de Santo Agostinho em que este esclarece a relação entre as três dimensões, afirmando que o indivíduo só vive o presente, porém este tem várias facetas: "o presente das coisas passadas, o presente das coisas presentes, o presente das coisas futuras" (apud, LE GOFF, 2003, p. 209).

Nesse mesmo sentido, Bosi (2003) aponta para a importância de se conhecer o passado, visto que "do vínculo com o passado se extrai a força para a formação do presente", e para o papel da memória nesse processo, uma vez que “a apreensão plena do passado é impossível" (BOSI, 2003, p. 53), uma vez que a passagem do tempo não ocorre de modo uniforme, sendo que cada indivíduo a percebe de modo específico de acordo com suas 
próprias concepções e visão de mundo. Assim, segundo a mencionada autora "a memória é sim, um trabalho sobre o tempo, mas sobre o tempo vivido, conotado pela cultura e pelo indivíduo.” (BOSI, 2003, p. 53).

A partir de tais premissas, considerou-se a relevância de se conhecer a gênese da criação de Brasília, cidade cosmopolita, que já nasceu grandiosa, moderna, futurística e, em especial, o sistema educacional revolucionário implantado nos primórdios da nova Capital, como condição necessária à compreensão da realidade atual e à projeção do futuro.

Conhecer os objetivos que se buscam alcançar em relação à educação, na contemporaneidade, reafirma a necessidade e a relevância de se ter realizado a pesquisa em pauta, tendo em vista que a reconstituição desse passado oferece novos elementos para se repensar a formação docente posta pela atualidade.

\subsubsection{Pesquisa bibliográfica}

A pesquisa bibliográfica se utiliza, fundamentalmente, de formulações teóricas de diferentes autores que se debruçaram para o estudo de determinado tema, sendo uma de suas principais contribuições a de permitir ao pesquisador contemplar uma gama de fenômenos de amplitude maior do que aquela que poderia investigar diretamente (GIL, 2008).

Assim, o pesquisador fundamenta-se em pressupostos e informações já constituídas por outros estudiosos, para, mediante a sua pesquisa, trazer novas contribuições ao conhecimento constituído. Segundo o referido autor, essa forma de investigação é imprescindível à pesquisa histórica, uma vez que há fatos passados que só podem ser conhecidos por meio de dados secundários.

Outra contribuição da pesquisa bibliográfica é apontada por Yin (2010), que lhe atribui importância não apenas na fundamentação da pesquisa, mas também para demonstrar a existência de lacunas do conhecimento e a pertinência do estudo em questão.

Dada a sua relevância para o desenvolvimento da investigação científica, Gil (2008) alerta sobre a necessidade de um trabalho criterioso na seleção das fontes bibliográficas, evitando-se, assim, possíveis equívocos, incoerências ou contradições, fatores que poderiam comprometer o resultado do trabalho de pesquisa.

No presente estudo desenvolveu-se a pesquisa bibliográfica de forma contínua, buscando aprofundamento na fundamentação teórica que contribuiu para a organização das informações relativas ao tema em análise. Entre os autores selecionados inicialmente, citemse os seguintes: Teixeira (1952, 1957 e 2001), Pereira (2011 e 2015), Le Goff (2003) (2008), 
Saviani (2008), Vicentini e Luigli (2009), Xavier (2000 e 2008), Paiva e Paixão (2002) além de acadêmicos que elaboraram teses e dissertações acerca da temática.

\subsubsection{Pesquisa documental}

A pesquisa documental requer a identificação, seleção e exploração das fontes documentais. Ao proceder a essa exploração, segundo Pimentel (2001), em se tratando de uma investigação histórica, o pesquisador deve atentar-se para que não haja uma incompreensão no fato estudado, uma fragmentação causada por não se embasar em evidências concatenadas. Nesse sentido, afirma a autora:

\footnotetext{
No processo de articulação do presente com o passado, o pesquisador voltase às suas raízes, ativa ou reativa a memória, distanciando-se assim de uma possível fragmentação quando procura, na investigação, o elo entre esses dois tempos históricos da atividade humana, para além de análises presentistas que o levariam apenas a ratificar o passado e glorificar o presente. A pesquisa historiográfica constitui-se em evidências coordenadas e interpretadas, exigindo do pesquisador o trabalho de suplantar sua própria contemporaneidade sem deixar-se cair, entretanto, num historicismo que se traduziria em anacronismo, numa interpretação errônea, distorcida do passado (PIMENTEL, 2001, p. 192).
}

Tendo em vista os objetivos da pesquisa, a análise de documentos configura-se como instrumento auxiliar, ou, mesmo, o principal meio de efetivação do estudo, como é o caso da pesquisa historiográfica.

No estudo realizado, a pesquisa documental foi basilar e, para tanto, utilizou-se, como fontes básicas, o acervo documental dos arquivos do Inep/Distrito Federal, do Arquivo Público do Distrito Federal e do grupo de pesquisa responsável pelos projetos "Educação básica pública do Distrito Federal (1956-1964): origens de um projeto inovador" e "Educação básica pública do Distrito Federal (1964-1971): desmonte de um projeto inovador”.

A respeito deste último arquivo mencionado, cabe apontar que possui acervo composto por documentos históricos sobre as origens do sistema público de educação na capital do país, sobre sua implantação e desafios enfrentados para sua consolidação. A natureza deste acervo está intimamente ligada à temática dessa pesquisa, o que o tornou de suma importância para o alcance dos objetivos propostos. O conteúdo do acervo provém de arquivos de instituições públicas e de acervos pessoais doados à pesquisa. Os documentos se diferenciam em sua materialidade e teor, e apresentam-se em diferentes suportes - impresso, 
iconográfico, áudio e vídeo - configurando-se como fontes primárias e secundárias para a pesquisa.

Segundo Pereira (2015), coordenadora dos citados projetos, "especial destaque deve ser dado às fontes criadas pelos pesquisadores com a utilização da história oral, mediante entrevistas realizadas com docente, gestores e estudantes pioneiros" (PEREIRA, 2015, p. 90).

Este acervo destina-se ao futuro Museu da Educação do Distrito Federal, cujo projeto encontra-se em fase avançada de execução e terá por objetivo a criação de um centro de documentação especializado sobre a temática educação no Distrito Federal. Concebido pelo grupo de pesquisadores como um "espaço de pesquisa, formação e memória” (PEREIRA, 2015, p. 90), certamente será de grande importância a todos que anseiam debruçar-se à pesquisa e estudos sobre os primórdios da educação do Distrito Federal.

A pesquisa documental realizada nesses espaços permitiu o alargamento do universo de busca, ampliando a possibilidade de se encontrar dados relativos ao recorte temporal estabelecido para a presente investigação.

Procedeu-se, ainda, ao exame de diferentes fontes, particularmente, de documentos oficiais que tratam de políticas públicas estabelecidas para a formação de professores, no aludido período, cuja busca realizou-se em arquivos de instituições governamentais, especialmente no Inep.

Entre os documentos utilizados destacam-se: o "Plano de Construções Escolares de Brasília", que possibilitou o conhecimento da proposta educacional da Capital Federal (TEIXEIRA, 1961, p.195-199); o "Relatório Quinquenal do Ministério da Educação e Cultura (1956-1960)", que dispõe sobre as políticas públicas na área educacional, com destaque ao novo sistema de educação proposto para o Distrito Federal; o Decreto $\mathrm{n}^{\circ} 38.460$, de 28 de dezembro de 1955, que trata da criação do Centro Brasileiro de Pesquisas Educacionais e dos Centros Regionais de Pesquisa Educacionais, por se tratar de instâncias que concretizavam as políticas públicas para a formação do professorado e o "Plano Trienal de Educação - 19631965”, que traz informações adicionais sobre os Centros Regionais de Pesquisa Educacionais, criados pelo INEP/MEC.

\subsubsection{História oral}

A história se faz por meio de movimento. As ações dos homens, em interação com seus pares, vão construindo, paulatinamente, passo a passo, a história da humanidade. O relato desse movimento, vivido ou conhecido por meios diversos, compõe a história oral. 
Trata-se de um procedimento metodológico que procura, por meio da composição de fontes e documentos, reunir "narrativas induzidas e estimuladas, testemunhos, versões e interpretações sobre a história em suas múltiplas dimensões: factuais, temporais, espaciais, conflituosas, consensuais" (DELGADO, 2010, p. 15).

Dessa forma, a história oral enquanto procedimento metodológico visa registrar impressões, experiências, lembranças dos sujeitos que se disponibilizam a socializar suas memórias e, assim, tem-se acesso a informações e situações que estariam fadadas ao esquecimento, por não se enquadrarem na história 'dita' oficial. Destaca-se essa técnica como privilegiada e bastante apropriada para pesquisas do tempo presente, uma vez que há a possibilidade de saber dos fatos diretamente daqueles que o viveram.

Ao se fazer a coleta de dados, por meio de gravação ou filmagem, é possível registrar como o sujeito investigado "reinterpreta seu passado por recortes mediados pelo acúmulo de experiências adquiridas, por sua visão de mundo, por seus valores e projetos, tudo isso orientado pelas vivências do presente" (MEKSENAS, 2002, p. 124). O autor considera fator fundamental a escolha dos depoentes, que devem ser "pessoas significativas" para elucidação da temática a ser investigada, ou seja, os entrevistados devem ser sujeitos portadores de dados relevantes sobre o tema e sobre as questões escolhidas.

O primeiro passo foi realizar o levantamento nominal das professoras do ensino primário à época da construção e instalação da nova Capital. Durante a pesquisa bibliográfica, foram localizadas algumas publicações ${ }^{6}$ que faziam menção ao nome das primeiras professoras a exercerem o ofício na Capital em construção. Porém sentiu-se a necessidade de ampliar esta relação no sentido de acessar o maior número possível de informações. Foram encontradas fontes primárias, como a relação de escolas primárias mantidas pela Novacap, de 1959, onde são relacionadas às professoras, bem como, o seu turno de trabalho, a série em que lecionavam, idade dos alunos e situação funcional dos docentes. Trata-se de relatório em que estão registradas setenta e uma professoras admitidas entre 1957 e 1959, que atuavam em doze escolas primárias e dois jardins de infância. Há também outro documento da Novacap, um memorando manuscrito, onde estão relacionadas as oito primeiras professoras admitidas na Escola Júlia Kubitschek, datado de 14/09/1959 e uma relação de docentes publicada na

${ }^{6}$ DISTRITO FEDERAL. Departamento de Planejamento Educacional. A origem do Sistema Educacional de Brasília: Criação da Caseb, 22/12/1959. Brasília, 1984.

SILVA, Ernesto. História de Brasília: um sonho, uma esperança, uma realidade. 3. ed. Brasília, DF: Linha Gráfica, 1997. 
Revista Brasília ${ }^{7}$. De posse desses documentos, buscou-se, nos arquivos já mencionados, dados referentes às professoras indicadas nessas relações.

Cabe apontar, ainda, que tais registros inexistem em arquivos da Secretaria de Educação do Distrito Federal - SEDF, evidenciando-se que os arquivos/documentos escolares daquela época não foram preservados por essa instituição. Destaque-se que a documentação existente, relativa a este período da história da educação de Brasília, refere-se a coleções particulares posteriormente doadas a instituições que trabalham com a preservação da memória, como as consultadas e já mencionadas nessa pesquisa.

Paralelamente à investigação referente às primeiras escolas da futura Capital, buscou-se, junto aos arquivos do Inep, documentação relativa à participação de professores do Distrito Federal nos cursos promovidos por essa instituição, uma vez que a pesquisa bibliográfica indicava a ocorrência de diversos eventos de formação docente sob iniciativa desse instituto.

No acervo do grupo de pesquisa do projeto "Educação básica pública do Distrito Federal (1956-1964): origens de um projeto inovador" encontrou-se material concernente às entrevistas já empreendidas com o grupo de professoras pioneiras. Tais entrevistas tiveram início em meados dos anos 2000, e, ainda se realizam, com o propósito de arrebanhar a maior quantidade possível de informações. Deste material, parte considerável encontra-se já degravada, transformada em documentação textual. Outra parte, porém, encontra-se ainda em forma de áudio ou vídeo, necessitando de trabalho mais detalhado na garimpagem das informações.

Destaque-se a importância desse material, uma vez que várias componentes das listas acima arroladas para essa pesquisa já faleceram, fato que tornaria mais difícil a busca pelas informações passíveis de elucidar as questões propostas para esta dissertação, e em alguns casos, seria impossível. Também é relevante apontar, que, dentre as docentes constantes nas listagens oficiais, várias não possuíam qualquer material que pudesse esclarecer a sua participação nos fatos investigados nessa pesquisa. Dessa forma, foram extraídas informações de diversos depoimentos orais, porém, não da totalidade das professoras que fizeram parte desse momento histórico, por ausência de documentação alusiva a estas outras.

Após localizar os depoimentos das professoras, realizou-se leitura ou audição inicial para conhecer o teor do material, seguida de uma segunda, já buscando dados relevantes para

${ }^{7}$ REVISTA BRASÍLIA, números 4 e 40. 
a pesquisa em pauta. Buscou-se, então, trechos onde eram tratados assuntos referentes à capacitação, coordenação, estudos.

Os dados coletados na pesquisa foram ordenados sob a forma de fichas de leitura e elaboração de quadros nos quais foram registrados aspectos relevantes obtidos dos relatos das professoras e nos demais documentos investigados, o que possibilitou uma visão panorâmica das informações levantadas.

Inicialmente, foram analisados os depoimentos das professoras pioneiras, com o propósito de reunir indícios relativos à participação de cada docente em atividades de formação e identificar as estruturas constituídas no período de fundação de Brasília para implementação de seu projeto educativo e qualificação de professores. Estabeleceu-se, em seguida, diálogo entre esses dados e os oriundos de outras fontes documentais analisadas.

A metodologia de história oral requer que a organização e interpretação dos dados se deem por meio de um processo complexo de análise sistemática e de uma descrição coerente, a fim de promover a sua articulação com os referenciais teóricos e os pressupostos norteadores da pesquisa. Desta forma, foram agregadas as evidências descobertas ao longo da investigação com a finalidade de compor, juntamente com os questionamentos apresentados, um quadro teórico consistente, detalhado no próximo capítulo. 


\section{POLÍTICAS EM EDUCAÇÃO NO CONTEXTO HISTÓRICO DA FUNDAÇÃO DE BRASÍLIA}

Este capítulo tem como finalidade trazer elementos históricos pertinentes à construção de Brasília, em especial, o que se refere à implantação de políticas educacionais de qualificação de professores do ensino primário. Para tanto, faz-se breve panorama histórico das diretrizes preconizadas para o ensino público na nova Capital federal, bem como as ações empreendidas pelo Inep para atender a esse fim.

\subsection{Aspectos históricos que compõem o cenário de fundação da nova capital federal (1957-1960)}

A ideia de transferência da Capital Federal já preexistia no Brasil desde o período colonial, no século XVI. É possível elencar para defendê-la ao menos dois pontos de vista: o da história oficial, e outro que aponta a busca pelas riquezas existentes no Centro-Oeste brasileiro.

Segundo a visão oficial, a mudança da capital representava a função civilizatória de uma capital situada no centro geográfico do país, em que se tratava a interiorização como questão de segurança. Segundo Varnhagem ${ }^{8}$ (MEMORIAL JK, 2014), a atitude de ter a capital no interior seria mais apropriada para civilizar o interior do país e ainda promover o desenvolvimento utilizando suas riquezas, e também o comércio das províncias.

Quando, enfim, ela ocorreu, justificava-se pela necessidade inadiável de integração nacional, de se responder aos anseios da nação em adentrar a era da modernidade, do urbanismo e do industrialismo.

De tal forma que, quando a nova Capital foi construída e ocorreu a mudança do governo, o Presidente Kubitschek afirmou que Brasília representou, então, conquistar algo que nos pertencia apenas no mapa, pois, dos oito milhões e quinhentos mil quilômetros quadrados que compunham o território brasileiro, seis milhões ainda encontravam-se despovoados. (MEMORIAL JK, 2014). Nesse discurso do Presidente fica evidenciada a preocupação com a teoria alemã de espaço vital, de Haussofer, a qual intentava legitimar a ocupação de áreas desocupadas ou não habitadas dos países de baixa densidade demográfica, pelos países superpovoados. Nessa ótica de compreensão, o francês Paul Reynaud já sugerira, em 1935, a criação de um novo Estado, no planalto central brasileiro, então quase desabitado,

\footnotetext{
${ }^{8}$ Francisco Adolfo de Varnhagen - o Visconde de Porto Seguro é considerado um dos fundadores da historiografia brasileira como conhecimento documentalmente organizado.
} 
para abrigar os excedentes populacionais do mundo, sendo que no período pós-guerra essa ideia ainda persistia.

Outra versão para a ocupação do planalto central goiano consiste no pensamento de Bertran (1994) que afirma a existência de um conhecimento prévio das riquezas vegetais e minerais existentes nessas terras muito antes do que é apontado nos compêndios de estudo tradicionais.

Bertran (1994) aponta duas situações que, do ponto de vista desta análise, evidenciam a possibilidade de haver outros interesses pela ocupação do planalto central brasileiro. A primeira diz respeito ao documento intitulado Tratado Descritivo do Brasil, de autoria de Gabriel Soares de Souza, o qual Bertran considera como um "formidável estudo sobre o Brasil da época". Nesse estudo, Soares de Souza relata sobre "[...]diversos rumores vindos do vasto desconhecido interior do país sobre enormes riquezas minerais em ouro e prata, superiores talvez, supunha, às do México e do Peru.” (BERTRAN, 1994, p.24).

Essas notícias chegam à Corte portuguesa e fazem com que o rei D. Sebastião envie Gabriel de Souza à sua procura, em 1591. Porém esse falece no ano seguinte sem conseguir o intento de alcançar o objetivo de encontrar "uma montanha de ouro perdida no interior profundo do Brasil, coroada por uma crista rochosa de esmeraldas.” (BERTRAN, 1994, p.24)

No segundo exemplo, O mencionado autor refere-se a um goiano, autodidata, o qual demonstra "senso de observação geomorfológico, florístico e botânico [...] em muitos casos superior aos botânicos da Comissão Cruls”, que no final do século XIX elabora extensa taxonomia do cerrado. Trata-se de Joseph de Mello Álvares, que em seus manuscritos, ao referir-se às terras do planalto central, descreve as inúmeras riquezas deste bioma. (BERTRAN, 1994, p. 24 e 35).

Percebe-se, assim, que a ocupação do interior brasileiro tem sido tema relevante ao longo da história deste país. Fatores de ordem geográfica, econômica, política e social foram responsáveis por influenciar a decisão do Presidente Kubitschek na transferência da Capital brasileira do litoral para o interior. Ao final dos anos de 1950, o Presidente JK afirma que o Brasil estava diante de "uma encruzilhada histórica": por um lado tinha-se o mundo rural visto como representação do passado, de "imobilismo e atraso" e, como anteposição a este, se apresentava a modernidade baseada, sobretudo, na industrialização. Era necessário fazer-se o novo, o moderno, estabelecer-se a mudança que possibilitaria ao país vencer o subdesenvolvimento (OLIVEIRA, 2012, p.1).

Acreditava-se, então, que "as forças do novo" possibilitariam a inserção do país ao patamar de desenvolvimento. Datam desse período os movimentos de renovação cultural 
atrelados a esse ideário: arquitetura moderna, bossa nova, cinema novo. Ao meio dessas manifestações modernistas, a construção de Brasília significou um desafio, muito além da edificação de prédios, pois se constituiu a meta-síntese do governo JK. A cidade ergue-se sob o marco da inovação em diferentes setores: urbanístico, arquitetônico, paisagístico e educacional. Pretendia-se, dessa forma, estabelecê-la como modelo de modernidade que irradiasse para todo o país. Sua construção, em meio à região Centro-Oeste, ao mesmo tempo em que possibilitava a necessária interiorização do país, também se apresentava ao mundo como símbolo arrojado da inventividade brasileira.

Matéria publicada pela Revista Brasília descreve o que se projeta para a nova cidade:

Uma cidade planejada deve revestir-se de roupagens novas e modernas. O local sobre o qual estamos construindo Brasília foi escolhido cientificamente: o clima é ameno; a salubridade excelente; a água abundante; a terra fértil e a paisagem deslumbrante. Edifícios de linhas modernas serão erguidos. A cidade foi idealizada e desenhada por cérebro privilegiado e mãos hábeis. Tudo em Brasília deve estar no limiar da perfeição. O sistema educacional estará, portanto, entrosado nessa organização. O plano organizado pelo Ministério da Educação proporcionará escola e oportunidade para todos (REVISTA BRASÍLIA, 1957, p. 8).

Aspirava-se que a nova Capital representasse o que havia de moderno em todas as esferas. Para a sua concepção foram escolhidos os melhores profissionais como Lúcio Costa, Oscar Niemeyer, Burle Marx, Athos Bulcão e Israel Pinheiro, dentre outros, que participaram da elaboração dos projetos e da construção de Brasília. Para a área de educação não poderia ser diferente e, na busca pela vanguarda, Anísio Teixeira é responsabilizado pelo planejamento de seu sistema educacional.

Esse intelectual destacava-se no cenário educacional brasileiro pela sua atuação em importantes cargos públicos de gestão da educação, nos quais sempre atuou em prol da escola pública, democrática e universal.

\subsection{Processo histórico da formação de professores primários no Brasil}

Saviani aponta que Comenius, no século XVII, é um dos primeiros a tratar sobre a necessidade de se promover a formação dos professores, sendo que a instituição do primeiro local de ensino destinado a essa finalidade foi feita por La Salle, em 1684, no Seminário dos Mestres. Segundo o citado autor, uma resposta institucional para essa questão surgiu somente no século XIX, posteriormente a Revolução Francesa, quando foi aventada a questão da 
instrução popular. Data desse período o tratamento de Escolas Normais como "instituições encarregadas de preparar professores" (SAVIANI, 2009, p. 143).

O desafio da formação de professores, no Brasil teve início após a expulsão dos jesuítas e a implantação das Reformas Pombalinas ${ }^{9}$, em 1759, época em que ocorre o envio dos professores régios pela metrópole. Com a vinda da realeza para o Brasil, em 1808, organizou-se a direção estatal sobre a educação formal. Tal evento significou o estímulo para as primeiras experiências de composição de um sistema de instrução primária, momento em que se inicia a profissionalização dos professores. A inexistência de cursos de formação de professores ocasionava, então, a indicação destes, mais em virtude de seus atributos morais que por competência profissional.

Era de se esperar que a escola normal adotasse um direcionamento didáticometodológico específico, porém, o que se observou foi um currículo idêntico ao das escolas de primeiras letras, já existentes, demonstrando um enfoque escolar centrado no processo de ler e escrever do professor, subvalorizando questões relativas ao preparo técnico-pedagógico sendo que a formação via escola normal só veio a se estabilizar a partir de 1870, trinta e cinco anos após a inauguração da primeira escola normal, em Niterói. (SAVIANI, 2009).

Tal demora em vicejar as escolas normais possibilitou o surgimento de opositores à sua existência, como nos relata o citado autor, verificada na posição tomada por Couto Ferraz que por considerar essas escolas "onerosas" e "ineficientes" decidiu, enquanto presidente da Província do Rio de Janeiro, fechar a Escola Normal de Niterói, em 1849.

Em seu lugar, foram contratados professores adjuntos - sem formação específica que atuavam como ajudantes nas salas de aula, função na qual se preparavam para, futuramente, incumbirem-se da sua própria classe. Visto que esta estratégia não prosperou, as escolas normais continuaram a ser estabelecidas e a escola de Niterói foi reaberta após dez anos, em 1859.

O padrão de organização e funcionamento das escolas normais foi fixado com a reforma da instituição pública do Estado de São Paulo, em 1890, já com o intuito de preparação de professores e da adoção de metodologias modernas. Todavia, o estabelecimento desse padrão para a escola normal não se configurou em avanço considerável, uma vez que se conservou o modelo existente, que era o de estrita aprendizagem dos ensinamentos a serem transmitidos.

\footnotetext{
9 Reforma educacional, ocorrida a partir da expulsão dos jesuítas em 1959, pelo Marquês de Pombal, ministro da Fazenda português que consistiu na substituição da metodologia eclesiástica jesuítica pelo ensino público e laico, inspirado em ideias iluministas.
} 
Adentrando o século XX, a formação de professores sofreu a influência do processo de industrialização, especialmente a partir das décadas de 1920-1930, tendo em vista atender às demandas de mão-de-obra. Nessa perspectiva, tem início, em 1933, em São Paulo uma reforma radical do ensino primário - por meio do Código de Educação do Estado de São Paulo, que estabelece que o ensino público primário passe a ser obrigatório e gratuito às crianças de oito a quatorze anos de idade e passe a ter a duração cinco de anos - visando estendê-lo a toda a população e não apenas às classes abastadas (TEIXEIRA, 2001). Segundo o autor, a ampliação da oferta de vagas para o magistério decorreu da necessidade de formação de mão-de-obra especializada e à urgente escolarização da população, fato que gerou uma pressão pela formação de professores.

Novo modo de conceber a formação de professores é inaugurado a partir de 1932, com a abertura dos Institutos de Educação, vistos não apenas como espaços de transmissão de conhecimentos, mas também de pesquisa e disseminação de uma nova cultura de educação.

Assim, nas palavras de Saviani (2009),

[...] percebe-se que os institutos de educação foram pensados e organizados de maneira a incorporar as exigências da pedagogia, que buscava se firmar como um conhecimento de caráter científico. Caminhava-se, pois, decisivamente rumo à consolidação do modelo pedagógico-didático de formação docente que permitiria corrigir as insuficiências e distorções das velhas Escolas Normais (SAVIANI, 2009, p. 146).

A partir da reforma instituída pelo Decreto $\mathrm{n}^{\mathrm{o}} 3.810$, de 19 de março de $1932^{10}$, foram criados o Instituto de Educação do Distrito Federal, idealizado por Anísio Teixeira, em 1932 e dirigido por Lourenço Filho, e o Instituto de Educação de São Paulo, em 1933, dirigido por Fernando de Azevedo. Cabe destacar que esses educadores exerceram liderança no movimento de renovação da educação no Brasil, sendo os institutos inspirados nas ideias defendidas no Manifesto dos Pioneiros da Educação Nova, de 1932.

A criação do Instituto de Educação no Rio de Janeiro, em substituição ao curso normal, significou um avanço relevante no nível de preparação dos futuros professores, pois seria o local de "cultivo de educação" e não apenas espaço de transmissão de conhecimento, possibilitando formar uma nova geração de docentes de modo compatível com os ideais propostos no Manifesto dos Pioneiros da Educação Nova, preconizando a educação como

\footnotetext{
${ }^{10}$ O Decreto $N^{o} 3.810$, de 19 de março de 1932, reorganiza a antiga Escola Normal do Distrito Federal, e cria o Instituto de Educação, que reúne as escolas, Primária, secundária e de Professores e o Jardim de Infância que estarão sob a administração central do diretor da Escola de Professores. Institui, também, a formação de professores em nível superior.
} 
propulsora para o avanço da nação por meio de sua intervenção na realidade educacional. $\mathrm{O}$ educador Lourenço Filho define os Institutos da seguinte maneira:

Não representam obra definitiva. Exprimem um momento de evolução na primeira tentativa de renovação do preparo dos mestres primários brasileiros que este Instituto vem realizando [...] Mas a obra já realizada em cinco anos convence de sua superioridade aos que, de ânimo sincero, o queiram conhecer em suas minúcias (LOURENÇO FILHO, 2001, p. 37).

Em tese de doutorado, Pinto (2006) relata que o Instituto de Educação foi criado para ministrar educação para ambos os sexos e oferecer cursos de formação inicial e continuada para professores. Sua composição contava com uma escola secundária e uma escola de professores, esta última possuía, em anexo, um jardim de infância e uma escola primária, que objetivavam a instrução, orientação, demonstração e prática de ensino para a formação dos futuros professores primários. A conexão entre estes níveis de ensino era a sua concepção comum de se promover a formação apropriada aos professores.

Segundo a supramencionada autora, o slogan reforma do ensino primário pela reforma na formação de professores serviu como pano de fundo para a constituição do Instituto de Educação do Rio de Janeiro, o qual se pautou pelo estabelecimento de uma nova cultura pedagógica por meio da formação do professorado primário. Aspecto importante, apontado por Pinto (2006), é de que também os cursos de extensão e de aperfeiçoamento oferecidos aos mestres em exercício desenvolviam-se mediante novas bases educacionais, inclusive era-lhes oportunizado observar o funcionamento da Escola Primária do Instituto, que desempenhava papel central na disseminação das novas propostas pedagógicas.

Não obstante, a realidade permaneceu distante do que a legislação preconizava em termos de estender a escolarização a toda população, bem como de ampliar e melhorar a formação docente.

Afora a carência de professores habilitados para o exercício da profissão, a expansão do acesso e a inclusão das classes populares na escola elementar deram-se à custa da redução da duração do curso primário, o que se refletiu na perda de qualidade do ensino. O mesmo ocorreu com os cursos de formação de professores, que, ao invés de serem ampliados, foram encurtados para atender à crescente demanda.

Há de se considerar que a instalação do Estado Novo, em 1937, no Brasil, atingiu os variados setores da sociedade. O campo educacional, como os demais, também foi alcançado pelas intervenções decorrentes da implantação do regime ditatorial e uma das consequências marcantes nesse setor foi o de estancar as mudanças progressistas em curso. 
Para Anísio Teixeira, a questão da formação de professores era "problema máximo da reconstrução educacional do Brasil, o que requeria da nação investir na criação de escolas tipicamente vocacionais, que integrassem os sistemas estaduais de educação, dentro de sua tradição original" (TEIXEIRA, 2001, p. 205). Isso significa dizer, segundo o autor, que a formação docente deveria ter em vista a realidade e a cultura regionais, considerando seus costumes e valores, como também o ensino de orientação pragmatista ${ }^{11}$, que privilegia a formação do indivíduo, sua inserção na sociedade e apreensão de valores para a vida, superando os preceitos do ensino enciclopédico tradicional. Do mesmo modo, o educador Lourenço Filho afirmava que a preparação cultural dos mestres deveria ser a melhor possível, tendo início no curso normal e estendendo-se, incessantemente, por toda a vida (LOURENÇO FILHO, 2011).

O educador Anísio Teixeira, no desempenho da sua missão, percebeu a precariedade do ensino público naquele Estado, conforme demonstrou em relatório intitulado "A situação educacional na Bahia" o que o desafiou a buscar novas formas de se pensar a educação. Esse caminho foi traçado quando, ao realizar curso de aprofundamento nos Estados Unidos da América, Anísio é influenciado pelo ideário da Escola Nova, concebida pelo educador americano John Dewey. Inspirado por essas ideias, Anísio projeta, em meados da década de 1940, o Centro Educacional Carneiro Ribeiro em área periférica da capital baiana, que também ficou conhecido como a Escola Parque de Salvador.

Naquele Centro desenvolveu-se uma experiência baseada em formas inovadoras de organização e funcionamento. Segundo o educador, a escola não deveria ser vista apenas como locus de instrução, mas onde se ofereceria "oportunidades completas de vida, o que compreendia atividades de estudo, de trabalho, de vida social e de recreação e jogos" (TEIXEIRA, 1962, p. 21). Tais oportunidades significaram na prática educação com dia letivo integral, onde as aulas de cunho informativo mesclavam-se com aulas de artes industriais, teatro, dança desenho, dentre outras.

Com essa experiência, Anísio buscava uma resposta à política de educação vigente à época, bastante reduzida, com professores também de preparo reduzido. A sua crítica se refere à ineficiência do processo que popularizou o ensino, porém não correspondendo em qualidade. Assim, Anísio ponderava que, apesar de sua ampliação, o sistema escolar ainda se destinava a poucos. $\mathrm{f}$

\footnotetext{
11 Segundo Teixeira (1959) a formulação mais completa desse método de filosofia encontra-se em John Dewey, que buscou integrar os estudos atuais ao campo de estudos de natureza científica baseados na observação e na experiência , no levantamento de hipóteses e na verificação de conclusões.
} 
Para esse autor, o gasto em educação deveria ser encarado como investimento e não ser contingenciado, uma vez que considerava a educação a forma mais eficaz de garantir a superação do subdesenvolvimento e do atraso cultural e científico da nação. Em pronunciamento junto à comissão legislativa que preparava a Lei de Diretrizes e Bases, em 1952, mostrava-se enfático ao afirmar que

(...) A educação de um povo, entretanto, é o mais amplo empreendimento das sociedades humanas. E os recursos têm de aparecer e acompanhar essa amplitude. À mobilização de vontades indispensável para se levar avante tão grande e imperioso empreendimento deve corresponder uma grande mobilização de recursos [...] em um plano conjugado para a construção dos prédios, a formação do magistério e a montagem definitiva de um sistema escolar público e gratuito (TEIXEIRA, 1952, p. 72-123.).

O educador baiano propunha a "educação comum" definida por ele como a escola pública, obrigatória, gratuita, universal e eficiente, não como favor da classe dominante aos menos possuídos, mas como um "direito do povo" (TEIXEIRA, 1957, p.70 - 80). Dessa forma, ele propunha que a educação deveria ser, necessariamente, de boa qualidade, extensiva a todos os brasileiros, que deveriam ter o direito de optar pela escola pública e gratuita sem decair em qualidade. Ele via a educação como a única saída para o subdesenvolvimento nacional. Em sua concepção, a formação de um "novo homem" com capacidade de pensar e agir conscientemente, integrando-se, dessa forma, à modernidade, cada vez mais impessoal e racionalista de que o mundo se revestia, era para ele, "questão de sobrevivência" (PEREIRA; ROCHA. In PEREIRA et. al., 2001, p. 29).

Conforme aponta Cordeiro (2016) o pensamento de Anísio Teixeira apresenta uma similaridade com a concepção de educação proposta para o milênio pelo Relatório DelorsUnesco, que se estrutura em quatro "princípios pilares: "aprender a conhecer", "aprender a fazer", "aprender a viver juntos”, “aprender a ser,". Considera, ainda, o indivíduo segundo a totalidade dialética do sujeito.

$\mathrm{Na}$ defesa desses ideais, cabe destacar a sua participação no movimento de renovação educacional no Brasil, nas décadas de 1920-1930, sendo Anísio um dos signatários do Manifesto dos Pioneiros da Educação Nova, em 1932. Nesse importante documento histórico em prol da renovação educacional buscava-se a primazia da questão educacional sobre os demais problemas nacionais, apontados nos planos de reconstrução nacional, e propunha-se a reformulação da política educacional brasileira baseada nos princípios democráticos da escola nova. Os ideais expressos no Manifesto ensejavam a educação como propulsora de uma 
formação mais técnica e científica, liberta dos entraves burocráticos e fragmentários então existentes, e, também, procuravam promover a inserção da escola à vida sociocultural.

Importante ressaltar que, embora tenha buscado em John Dewey o embasamento teórico para fundamentar sua concepção de educação, Anísio Teixeira preocupava-se em adequá-la à realidade e à cultura brasileiras, não abraçando as ideias deweyanas como mera transplantação (NUNES, 1999).

Se em Salvador, o Centro Educacional Carneiro Ribeiro situava-se em área periférica e os recursos financeiros para a sua execução foram contingenciados, no período de construção da Nova Capital, porém, contou-se com os expedientes necessários para que na moderna cidade, fosse instituído integralmente o plano sonhado por Anísio Teixeira (PEREIRA, 2011).

Ao elaborar o plano educacional para a nova capital, Anísio Teixeira viu a oportunidade de constituir, em pleno cerrado brasileiro, sua proposta de renovação do sistema educacional e a concretização dos ideais pedagógicos centrados na percepção de um novo paradigma, voltado para a educação pública, democrática e de qualidade que almejava para o país. No sistema preconizado, a escola pública brasiliense destinava-se tanto aos filhos dos estadistas quanto aos filhos dos operários, em um modelo educacional que não privilegiava as 'origens' da criança, mas que buscava desenvolver o potencial de todas elas.

\subsection{O plano de educação para Brasília}

A proposta educacional formulada por Anísio para Brasília previa, nos diversos níveis de escolarização, a promoção de uma educação integral e integradora, com jornada escolar de oito horas, nas quais seriam oferecidas às crianças atividades de estudos, de trabalho, de arte e de convivência social. Para o desenvolvimento dessas atividades planejou um conjunto formado por quatro escolas-classe e uma escola parque, nas primeiras seriam desenvolvidas atividades de estudo, propriamente dito, e, na escola-parque, de iniciação ao trabalho, nas oficinas de artes industriais, onde eram oferecidas atividades de tecelagem, tapeçaria, encadernação, cerâmica, cartonagem, costura, bordado e trabalhos em couro, lã, madeira, metal etc., como também a participação dirigida dos alunos de 7 a 14 anos em atividades artísticas, sociais e de recreação como: música, dança, teatro, pintura, exposições, grêmios e educação física. Para o educador, a implantação do novo modelo de escola representava do ponto de vista pedagógico, a superação da escola tradicional, centrada na figura do professor, que, transmitindo um saber enciclopédico, fragmentado, desfocado de seu 
contexto, baseava-se preponderantemente na memorização de conteúdos. A crítica dirigida à concepção de educação tradicional recaía na ênfase ao ensino reprodutivista, baseado exclusivamente na transmissão de conteúdos e em sua memorização, que levava o aluno à passividade, ao invés de promover-se a aprendizagem alicerçada numa educação compreensiva, com base no ensino ativo, na pesquisa e na criatividade do estudante, alçado ao centro do processo educativo.

Anísio criticava, ainda, a existência de educação encurtada em seus tempos e ações e ao ensino improvisado e ineficiente daí decorrente, que resultava em má qualidade no ensino. Desse modo, o Centro Carneiro Ribeiro foi construído como alternativa para esse grave problema. Para Anísio, o papel que a escola, e, em especial, a educação primária deveria desempenhar era por demais importante para dar-se em espaço de tempo tão reduzido como o turno de quatro horas, então adotado.

Constituído por dia letivo integral e pelo ensino primário de duração de cinco anos, essa instituição de ensino desenvolvia um programa composto por leitura, aritmética e escrita, ciências físicas e sociais, artes industriais, desenho, música, dança, e educação física, personificando uma escola que visava a educação, formação de hábitos, atitudes, como também o cultivo de aspirações e de preparo para os desafios impostos pela civilização moderna em constante transformação.

Como decorrência da nova concepção de educação, o professor deveria ter o preparo especializado indispensável ao exercício de suas funções, compreendendo a importância da pesquisa na prática do ensino, uma vez que a educação caracterizava-se como ato científico, requerendo estudo e aprofundamento continuado. O aperfeiçoamento do magistério tinha papel central no projeto de reestruturação educacional pensado por Anísio Teixeira, pois era a partir da melhor formação do professor, calcada em bases científicas, que a educação poderia alcançar status de ciência e, assim, promover a melhoria da qualidade do ensino e do sistema educacional como um todo.

Em entrevista à imprensa, ainda no período de construção de Brasília, Anísio pontua a sua preocupação com a formação docente, ao longo do exercício profissional, numa perspectiva de educação permanente:

[...] O magistério constitui uma das profissões em que a formação nunca se encerra, devendo o professor, terminado o curso regular, continuar pela prática e tirocínio o seu desenvolvimento [...] Hoje, além dessa prática e dêsse tirocínio [...] procura-se dar ao professor estágios, cursos e seminários destinados a apressar e sistematizar as conquistas que sòmente uma muito 
longa prática, e aos mais capazes, poderia dar. É o chamado "training in service", "educação no cargo" em expansão em tôdas as profissões de natureza, simultâneamente científica e artística (TEIXEIRA, 1958, s/n).

Tais ideias configuram-se no "Plano de Construções Escolares de Brasília", que “obedeceu o propósito de abrir oportunidade para a Capital Federal oferecer à Nação um conjunto de escolas que pudessem constituir exemplo e demonstração para o sistema educacional do País". Nesse plano, Anísio propõe a construção de "escolas classe" e "escolas parque", que deveriam se situar no interior das quadras e nas proximidades da residência dos alunos a fim de que esses não necessitassem deslocar-se por um longo percurso (TEIXEIRA, 1961, p.195-199).

Depreende-se pelo exposto, que na nova Capital ocorreu um movimento de relevância para a história da educação brasileira, pois se intentava realizar nessa cidade uma experiência de grande vulto, a ser posteriormente estendida a todo o território nacional. A importância que o ensino em Brasília assume é evidenciada no Relatório Quinquenal do MEC (1956-1960), tornando evidente que a educação brasiliense não seria "um mero adendo, mas uma espécie de culminância do trabalho desenvolvido pelo Ministério ao longo daqueles anos” (MENDONÇA, in PEREIRA, et. al., 2011, p. 13).

Os princípios educacionais inovadores defendidos por Anísio Teixeira assentam-se na concepção de a escola como um ambiente dinâmico, em íntima conexão com o meio em que está inserida, organizada à maneira de uma comunidade "palpitante" pelas soluções de seus problemas, uma "comunidade em miniatura", e podem ser traduzidos pela defesa de uma educação democrática, gratuita, como direito de todos os cidadãos, tendo o trabalho como fundamento da sociedade humana. Nessa perspectiva, revela-se o caráter social e eminentemente público da escola comum, ou única, destinada a todos, com fundamento no direito natural de cada indivíduo à educação, cuja finalidade é "dirigir o desenvolvimento natural e integral do ser humano em cada uma das etapas de seu crescimento" (AZEVEDO et. al. 2010, p. 40).

Para tanto, caberia ao professor da escola elementar estar apto a promover uma educação que atendesse a necessidade de vida e convívio social do aluno, tendo em vista o seu desenvolvimento artístico, físico e recreativo e sua iniciação ao trabalho. O docente deveria, então, atuar mediante uma organização diferenciada de jornada escolar, de oito horas de duração, dividida em atividades de estudo, de trabalho e de lazer.

Embora houvesse a exigência de habilitação para o magistério, os docentes que vieram à Brasília procediam de regiões diversas e se defrontavam com a necessidade de desenvolver 
práticas pedagógicas inovadoras. Diante desse quadro, a formação dos professores em exercício constituiu-se alvo de preocupação da administração do ensino nos primórdios de Brasília. Pelas fontes consultadas, especialmente pelos relatos dos primeiros docentes, evidencia-se que essa tarefa foi conduzida pelo Inep que, à época, representava "o centro de inspiração do magistério nacional” (GUIMARÃES, 2008b, p. 2), promovendo a elevação do seu nível profissional, por meio de assistência técnica e financeira, mediante recursos oriundos do Ministério da Educação e Cultura. Essas ações do Inep materializam-se sob a forma de treinamento e aperfeiçoamento do magistério. Segundo o Relatório Quinquenal, esse Instituto, por meio da Divisão de Aperfeiçoamento do Magistério - DAM, ofereceu aos professores das diversas regiões brasileiras "conferências, aulas, debates em seminários, visitas, exposições” (MEC, 1960, p. 201) sobre as várias disciplinas do currículo do curso normal, especialmente sobre a didática específica das disciplinas que compõem o currículo da educação primária.

\subsection{O Inep e a qualificação de professores no Brasil (1950/1960)}

Ao se analisar o sistema educacional brasileiro das décadas de 1950/1960 há, necessariamente, que se abordar duas entidades: o educador Anísio Teixeira, no campo individual, e o do Instituto Nacional de Estudos e Pesquisas Educacionais Anísio Teixeira Inep, no campo institucional. Tal fato se dá em virtude das ações empreendidas por Anísio, enquanto educador e homem público, e do papel de destaque ocupado pela referida instituição como órgão gestor e empreendedor de políticas públicas, no referido período (MENDONÇA, 2008).

O Inep foi criado em 1936 quando o ministro Gustavo Capanema, ao reformular o Ministério da Educação e Saúde, organiza o Instituto Nacional de Pedagogia. Porém, sua efetiva instalação ocorreu somente em 1938. Posteriormente, o órgão passa a denominar-se Instituto Nacional de Estudos Pedagógicos, consoante o Decreto-Lei no 580, de 30 de julho de 1938. Conforme o art. $2^{\circ}$ do referido Decreto, eram suas atribuições:

- Organizar documentação relativa à história e ao estudo atual das doutrinas e das técnicas pedagógicas, bem como das diferentes espécies de instituições educativas;

- Manter intercâmbio, em matéria de pedagogia, com as instituições educacionais do País e do estrangeiro; 
- Promover inquéritos e pesquisas sobre todos os problemas atinentes à organização do ensino, bem como sobre os vários métodos e processos pedagógicos;

- Promover investigações no terreno da psicologia aplicada à educação, bem como relativamente ao problema da orientação e seleção profissional;

- Prestar assistência técnica aos serviços estaduais, municipais e particulares de educação, ministrando-lhes, mediante consulta ou independentemente desta, esclarecimentos e soluções sobre os problemas pedagógicos;

- Divulgar, pelos diferentes processos de difusão, os conhecimentos relativos à teoria e à prática pedagógica;

A administração do Inep, desde sua fundação até 1952, coube a Lourenço Filho, que o organizou em seções, delimitou suas funções, bem como o trabalho relativo à documentação, intercâmbio e divulgação de dados educacionais. A característica marcante dessa administração foi a ênfase dada aos estudos e pesquisas no campo educacional. De acordo com Saviani (2012), o citado educador foi "o grande cultivador e difusor das bases psicológicas do movimento renovador da educação no Brasil” (p. 294).

A direção seguinte coube a Murilo Braga, o qual se empenhou na construção de prédios escolares e estabeleceu as bases para os cursos de aperfeiçoamento de professores.

Cabe destacar, que após sua criação, o Inep assumiu uma atribuição não pensada por seus mentores, que foi a de executor de políticas públicas. Dentre as mais marcantes destas que lhe foram imbuídas estão: a participação no recrutamento de pessoal, a responsabilidade pelas construções escolares e as Campanhas dos Livros Didáticos e Manuais de Ensino Caldeme e a Campanha de Inquéritos e Levantamentos do Ensino Médio e Elementar Cileme sobre as quais se tratará adiante.

Apesar de ter assumido ações que, originalmente não lhe competiam, o Inep, desde a sua fundação, abarcou funções primordiais, como a documentação, a pesquisa e a divulgação pedagógica. Fiel a essa tripla vocação, o Instituto implantou e manteve, durante vários anos, a maior biblioteca brasileira a abrigar temas relacionados à educação, promoveu estudos de cunho estatístico e publicou a Revista Brasileira de Estudos Pedagógicos - RBEP. Segundo a visão de seus idealizadores, o Inep seria "um dos pilares da reformulação da educação brasileira - a reformulação sonhada pelos escolanovistas" (ROTTHEN 2008, p.19), sendo que, na apresentação do primeiro número desse periódico, o então ministro da educação, Gustavo 
Capanema, afirma que a linha teórica dominante para o campo da educação já estaria definida: a da escola nova e dos métodos ativos.

Em 1952, Anísio Teixeira assume a direção do Inep, permanecendo nesse posto até a instauração do governo militar, em 1964, quando foi afastado do cargo. Seu trabalho à frente desse órgão foi tão significativo que Rotthen (ROTTHEN, 2008) o consagrou como o verdadeiro fundador do INEP. Segundo esse autor, a atuação de Anísio não se resumiu apenas a um projeto, mas desenvolveu um verdadeiro programa de governo, no qual a formação do magistério nacional foi designada como eixo norteador das ações governamentais.

À época, manifestando-se criticamente em relação à política de educação popular reduzida, com professores também de preparo reduzido, Anísio afirmava que "a despeito da tremenda expansão do conhecimento humano, um paradoxal imediatismo escolar reduziu a duração dos cursos e do dia escolar, a fim de oferecer a maior número de alunos uma educação primária reduzida ao mínimo.” (TEIXEIRA, 2011, p. 201).

As deficiências constatadas na qualificação dos professores, em face da inadequação dos cursos de formação, não eram até então consideradas nas políticas públicas, fato que mereceu críticas do educador, especialmente pela "complacência" com que o país encarava o grave quadro educacional que, à época, evidenciava a existência de, aproximadamente, 50\% dos professores primários serem leigos e menos de 30\% dos professores secundários formados pelas Faculdades de Filosofia (TEIXEIRA, 2011, p. 201).

Uma das suas primeiras iniciativas na direção do Inep foi a de organizar pesquisas, possibilitando-se, assim, conhecer o real cenário educacional brasileiro. Esses estudos pretenderam mostrar desde o estado específico de cada escola, como também dados relativos às escolas em nível nacional. Segundo Lima (2008), Anísio realizou uma verdadeira radiografia do sistema escolar brasileiro.

A organização dessas pesquisas ocorreu sob forma de duas campanhas: a Campanha de Inquéritos e Levantamentos do Ensino Médio e Elementar - Cileme e a Campanha do Livro Didático e Manuais de Ensino - Caldeme, que serão detalhadas adiante, sendo que os dados delas provenientes serviram como indicadores para estabelecer as estratégias para o aperfeiçoamento de professores.

Em 1955, são criados o Centro Brasileiro de Pesquisas Educacionais (CBPE), no Rio de Janeiro e os Centros Regionais de Pesquisa Educacionais, (CRPE), em Porto Alegre, Recife, Salvador, Belo Horizonte e São Paulo, que, segundo Rotthen (2008), foram inspirados no modelo do Centro de Documentação Pedagógica, da França. Conforme afirma Mendonça é por meio do "CBPE que Anísio Teixeira transforma o Inep no cérebro pensante do 
Ministério" (2002, p. 12), tornando-o um grande centro de produção e formulação de políticas educacionais, que baseadas nos inquéritos sobre a realidade escolar brasileira, busca intervir nos sistemas de ensino, para modernizá-los e adaptá-los às novas necessidades de nação, em que a escola deve ser formadora de quadros especializados.

Com a fundação dos Centros Regionais de Pesquisa Educacionais - CBPE, Anísio Teixeira inaugura o papel de centralidade da figura do professor, cujo papel deixa ser o de transmissor de conhecimento para tornar-se, então, um pesquisador, verdadeiro promotor da cultura local. Fiel a esse princípio, Anísio irá centrar esforços na qualificação do professorado brasileiro, que para ele era prioridade: “[...] O ofício de educador exige o melhor conhecimento possível da criança e o melhor conhecimento possível da vida e de suas exigências, no sentido de capacidade de pensar e agir inteligentemente dentro da sociedade e da cultura ambiente" (TEIXEIRA, 1967, p. 246-253).

Para o autor, a educação mostrava-se fator decisivo para a transformação do País. Em seu livro "Educação não é Privilégio" (1957), Anísio defende a escola pública, comum, democrática, igualitária e unificadora. Com referência aos cursos de formação de professores apregoa a necessidade de terem alto padrão e contarem com numerosos formadores, o que implicava a utilização de largos recursos.

Para possibilitar que esse conhecimento, segundo o padrão referido pelo educador baiano, alcançasse todo o professorado brasileiro, seria necessário o estabelecimento de verdadeira rede de formação de professores, que elevando o nível de conhecimento e a qualificação individual do professorado permitisse, assim, a melhoria qualitativa no ensino nacional. Porém, como não se dispunha da vultosa quantia necessária para empreender a execução dessa qualificação em larga escala, optou-se pela alternativa de munir os professores de material didático que lhes desse suporte pedagógico. Essa demanda ensejou a criação, em 1953, das duas campanhas já mencionadas: a Cileme e a Caldeme.

A Cileme contou com a participação de técnicos e especialistas nas diversas áreas do conhecimento, com o intuito de investigar, com profundidade, a situação do sistema de ensino primário e secundário. A partir dos problemas levantados foram estabelecidas ações, em forma de projetos específicos, para sanar tais dificuldades. Esses projetos eram organizados de maneira autônoma, visando o objetivo específico a que se destinavam, embora fossem "subordinados a uma coordenação que estabelecia prioridades e orientava na busca de soluções aos problemas" (LIMA, 208, p. 69).

A Caldeme, por sua vez, foi criada com a finalidade de prestar apoio técnico aos professores, sob a forma de publicações, tendo em vista que não havia estrutura com 
capacidade para atendimento sob a forma de cursos a todos os docentes brasileiros. Essas publicações versavam sobre literatura pedagógica, cuja difusão fazia-se por meio de revisão de livros de leitura e pela análise dos livros didáticos utilizados nas escolas públicas, de nível elementar e secundário. Além dessa tarefa, competia-lhe a elaboração e distribuição de guias de ensino, de livros texto e de manuais de ensino para o uso dos professores, bem como a distribuição de material didático aos alunos (XAVIER, 2008).

Em 1955, após o período de desenvolvimento das aludidas campanhas, foi criado, pelo INEP, o Centro Brasileiro de Pesquisas Educacionais - CBPE. Esse órgão era responsável pela elaboração e implementação de estudos e pesquisas, tanto no campo educacional como no das ciências sociais, visando conhecer os problemas e necessidades particulares de cada região brasileira, para planejar e estabelecer políticas adequadas a cada setor. Essas pesquisas, também chamadas à época de inquéritos, serviam ainda como subsídios às ações voltadas para o aperfeiçoamento de professores.

O relatório da Coordenadoria de Cursos de Formação de Pessoal do Inep, datado de 1956, ressalta a importância do papel representado pelo CBPE, em face da prioridade atribuída à documentação pedagógica:

[...] Tudo que possa representar instrumento útil ao educador ou ao estudioso de educação, quer se trate de material de estudo ou de auxilio didático para realização de seu trabalho, é objeto de interesse do Centro. Seu objetivo é esclarecer e dar ao administrador, ao estudioso de educação, ao professor, instrumentos úteis a seus trabalhos e procurar estimular os mestres a buscarem os meios mais seguros de se aperfeiçoarem (PINHEIRO, 1956, apud ROTTHEN, 2008, p. 197).

Esse órgão representava o desejo de Anísio Teixeira de criar o espírito científico no professorado brasileiro, pois uma das funções do CBPE era oferecer aos professores acesso a metodologias inovadoras de ensino, baseadas nos fundamentos científicos das ciências sociais, com o objetivo de aperfeiçoar a prática docente (GUIMARÃES, 2008a).

Os CRPE eram as instâncias responsáveis por materializar essas ações sendo que o seu papel era o de investigar e realizar experiências educacionais nas diferentes localidades, utilizando as metodologias das ciências sociais e, simultaneamente, formar especialistas em educação, na maior parte das vezes, ocupantes dos postos de direção ou superiores na hierarquia do sistema, que aplicariam na administração do ensino os conhecimentos adquiridos (GUIMARÃES, 2008a).

Cada CRPE possuía uma identidade cultural adequada à região em que se inseria. Assim, pode-se observar o perfil de cada um, traçado por Luigli (2003): 
- O CRPE de São Paulo caracterizou-se pelo predomínio da pesquisa de cunho sociológico. Dentre os CRPE, foi o mais fiel ao projeto pensado por Anísio Teixeira, ao vincular-se ao Departamento de Filosofia da Universidade de São Paulo e sediar cursos de aperfeiçoamento técnico-educacional para o Brasil e América Latina, sob patrocínio da UNESCO.

- O CRPE do Rio Grande do Sul foi antecedido por um Centro de Pesquisas que coordenava a reforma de ensino estadual, assim quando de sua inauguração o estado já possuía "uma sólida produção em termos de pesquisa psicológica" (LUIGLI, 2003, p. 5). Em 1959, integra-se à Universidade do Rio Grande do Sul, momento em que há um avanço nas pesquisas e tem início o trabalho de formação de professores.

- O CRPE de Pernambuco foi dirigido por Gilberto Freire, de onde adveio um direcionamento para as particularidades regionais e a presença de um projeto educativo adaptado à sociedade nordestina, buscando a valorização de sua cultura e a superação da miséria.

- O CRPE de Minas Gerais iniciou suas atividades em 1956 sob a direção de Mário Casasanta, o qual desfrutava de papel proeminente na cultura mineira, sendo diretor do Instituto de Educação de Belo Horizonte e nomeado, em 1957, chefe da equipe brasileira do PABAEE- Programa de Assistência Brasileiro-Americana ao Ensino Elementar. Este CRPE estabeleceu convênios para a ministração de cursos no Instituto de Educação, como também para formação de professores e produção de material didático, em parceria com o PABAEE. ${ }^{12}$

- O CRPE-MG exerceu uma posição de destaque no cenário educacional mineiro, tendo como característica mais expressiva o trabalho com pesquisa e a formação docente, as quais se focaram no ensino primário.

- O CRPE da Bahia destaca-se dos demais por ter sua experiência educacional iniciada oito anos antes dos demais, com a criação da Escola-Parque, em 1947, a qual era uma iniciativa de educação integral para as classes menos favorecidas. Em 1955, o CRPE instalase ao lado da Escola-Parque, iniciando a oferta de cursos de qualificação de professores.

A partir de 1957 o Centro passou a atuar em duas vertentes: a de Aperfeiçoamento do Magistério e Escolas Experimentais e a de Documentação e Informação Pedagógica, o que tornou o trabalho mais dinâmico.

\footnotetext{
${ }^{12} \mathrm{O}$ item 3 dessa dissertação tratará mais especificamente desta Instituição de formação docente.
} 
Na estrutura do Inep, a Divisão de Aperfeiçoamento do Magistério - DAM era a executora das ações para o magistério e, juntamente com o CBPE, mediante parcerias com as secretarias de educação e órgãos internacionais, ofereciam a docentes e supervisores de todo o país cursos de formação, estudos sobre programas de ensino primário, publicação de guias de ensino e material de apoio para o professorado, com o propósito de que se inaugurasse no país uma nova mentalidade pedagógica (MACEDO, 2007). Esses cursos contavam com professores bolsistas que se deslocavam de suas regiões para os CRPE e para o CBPE com o intuito de adquirirem conhecimentos especializados em determinada temática (LIMA, 2008).

Como visto, a função de criação de estratégias de promoção de profissionalização do magistério era de competência da DAM, que dispunha de uma instituição escolar - a Escola Guatemala $^{13}$ - para funcionar como "campo de experiência para realizações no âmbito da educação primária" e propiciar cursos, estágios e seminários para professores, como também efetuar a distribuição de literatura de assistência ao magistério. Essa escola tornou-se referência no trabalho de formação de professores no Brasil (GUIMARÃES, 2008b).

Macedo (2007) aponta para o papel central ocupado pela Escola Guatemala entre as ações de formação de professores e indica que a análise das rotinas e variações progressivas dessa escola permitiria transformá-la em um espaço de pesquisa científica relacionada a métodos e recursos de ensino, a programas para o curso primário, assim como a análise para o sistema de promoção. $\mathrm{O}$ conhecimento ali produzido serviria como base para o avanço e para estímulo do professorado em todo país e, consequentemente, ao melhor desenvolvimento das aprendizagens dos discentes.

O referido autor destaca que os "meios" necessários para a organização do trabalho experimental, realizado na Escola Guatemala, incluía, nos cursos para a formação de professores, orientações metodológicas que pressupunham trabalho segundo "linhas mais ou menos definidas", que era considerado importante "como base para um trabalho mais livre, futuro" Deste modo, as linhas de atuação estavam concentradas no "Sistema de Avanço Progressivo" 14 e em mais duas vias estratégicas: o "Método de Projetos" e o "Método de Alfabetização". O "Método de Projetos" fundamentava-se em uma prática pedagógica que se

\footnotetext{
${ }^{13}$ A Escola Guatemala - EG era instituição de caráter experimental situada no Rio de Janeiro, conforme proposta de Anísio Teixeira. Era vinculada à DAM-CBPE/INEP, tendo sido inaugurada em abril de 1954 pelo governo do então Distrito Federal e transformado no ano seguinte no primeiro Centro Experimental de Educação Primária do INEP.

${ }^{14}$ Sistema proposto pela Prof. ${ }^{a}$ Lúcia Pinheiro que objetivava alcançar maior produtividade do ensino primário utilizando-se dos conhecimentos da biologia, psicologia educacional e da estatística aplicada à educação como meios de desenvolver o aumento do rendimento escolar, tornando o aluno mais "rendoso e proveitoso", utilizando suas potencialidades e condições de aprendizagem, e, ainda, privilegiando o ritmo individual do aluno, buscando compreendê-lo em sua totalidade.
} 
dava por meio da pesquisa e do estímulo à cooperação e à solidariedade e ao desenvolvimento de "um tipo de aprendizagem que levasse o aluno a desenvolver hábitos de estudo, pesquisa e leitura" (MACEDO, 2007, p. 28). Aponta, ainda, que essa escola atuava no sentido de que o professor adquirisse conhecimentos e técnicas úteis para o desempenho de sua função, sendo para isso fundamental a observância dos diversos aspectos que influenciam sua atividade, atribuindo importância à percepção da situação social do aluno. (MACEDO, 2007).

Buscava-se que a EG funcionasse como uma disseminadora de ideias pedagógicas fundadas no princípio de "alteração das relações de aprendizagem, no sentido de torná-las mais dinâmicas, democráticas e participativas” (MACEDO, 2007, p. 39 e 42).

Autores como Mendonça (2007 e 2008), Xavier (2008), Rotthen (2008), Breglia e Lima (2008) e Guimarães (2008a e 2008b) são enfáticos em afirmarem a importância do CBPE e CRPE no cenário educacional brasileiro, no que se refere à qualificação de professores. Sua contribuição fundamental nesse setor se deu por meio da promoção de cursos, estágios e seminários de atualização e aperfeiçoamento do magistério primário e normal.

Estudo sobre a formação de professores no período de 1950-1960 aponta para o considerável investimento no processo de formação docente, seja em relação à infraestrutura material, como acomodação para os professores bolsistas e criação de escolas experimentais, bem como para a infraestrutura pedagógica, com a estruturação dos cursos, corpo docente com competência técnica, sistema avaliativo e metodologias apropriadas, numa evidência de que "a política do INEP à época tinha na formação de professores um foco privilegiado" (BREGLIA; LIMA, 2008, p.185).

Mendonça (2008) enfatiza o fato de os centros de treinamento possuírem estreita relação com as reformas governamentais empreendidas, no sentido de se alcançar o desenvolvimento da nação, as quais previam a escolarização das massas e por isso eram dependentes da formação adequada dos professores.

Como evidencia Guimarães (2008a), foram abrangentes e diversificadas as ações empreendidas pelo CBPE e pelos CRPE em prol da transformação da educação brasileira, ações essas intensificadas, principalmente, no quinquênio 1956-60. Segundo as palavras da referida autora,

[...] As iniciativas do INEP, através do CBPE e dos Centros Regionais, não foram poucas; ao contrário, suas ações envolveram tanto o campo das pesquisas em educação quanto à formação, atualização e aperfeiçoamento dos quadros docentes, administrativos e técnicos em diferentes níveis de 
ensino (elementar, médio e secundário). Entretanto, se os resultados apresentados não foram suficientes para modificar profundamente a situação educacional do país, ao menos serviram para mobilizarem intelectuais e educadores para uma ação orgânica em benefício do ensino, melhorando sua qualidade e ampliando as oportunidades escolares para as classes populares (GUIMARÃES, 2008a, p. 103).

A partir do exposto pode-se compreender que a atuação do Inep, por meio das ações desenvolvidas pelo CBPR e pelos CRPE, possibilitou o conhecimento detalhado e setorizado dos aspectos peculiares da cultura de cada região brasileira, permitindo, assim, a compreensão do contexto educacional brasileiro, em seu conjunto como também particularizado, de modo a permitir que a proposição de ações pontuais e adequadas ao grupo a que tinham como objetivo trabalhar e, consequentemente, a pertinência dessas ações. 


\section{QUALIFICAÇÃO DOS PROFESSORES DO MAGISTÉRIO PRIMÁRIO EM BRASÍLIA (1957-1964)}

Neste Capítulo são analisados os dados relativos às estratégias adotadas para a qualificação dos professores do magistério primário nos primórdios de Brasília. Uma das primeiras iniciativas visando patrocinar as atividades educacionais, ainda no período de construção da nova Capital, consistiu na criação do Departamento de Educação e Difusão Cultural, na Novacap ${ }^{15}$. Sob a égide desse Departamento, estabeleceu-se, desde o início, padrão elevado para o ingresso no magistério, mediante a exigência de diploma de curso normal, fato relevante considerando que, à época, aproximadamente 50\% dos professores em exercício no ensino primário no Brasil eram leigos (TEIXEIRA, 2001).

As exigências com o nível de formação docente não se deram ao acaso, já que havia o propósito de que a nova Capital abrigasse um modelo de educação consonante com os ideais cosmopolitas que se vislumbravam para a cidade. A princípio, o recrutamento das candidatas ao exercício da função deu-se mediante a procura de professoras entre esposas e familiares e engenheiros e funcionários que vieram participar da construção de Brasília (SILVA, 1997).

Em seguida, a busca ocorreu na circunvizinhança da nova Capital, especialmente no Estado de Goiás, mediante informações colhidas junto às escolas normais dessas cidades. Procurava-se por normalistas que houvessem se destacado pelo seu desempenho no curso, o que, provavelmente, lhes permitiria uma atuação satisfatória, razão pela qual eram convidadas a participar da seleção para o magistério da nova Capital $^{16}$.

Conforme as fontes consultadas, a primeira professora a exercer a docência no acampamento da Capital em construção foi Amábile Gomes Andrade, esposa de funcionário administrativo da Novacap. Embora a expectativa do governo fosse receber apenas os operários, sem suas famílias, já que inicialmente não havia infraestrutura para disponibilizar serviços educacionais, muitos trabalhadores trouxeram esposa e filhos, de modo que logo se fez necessário o atendimento a essa demanda. A referida professora foi convidada a ministrar aulas para essas crianças, em caráter emergencial, uma vez que possuía habilitação para o ofício. Como então não havia prédio destinado a essa finalidade, foi cedida a sala de reuniões da diretoria da Novacap para funcionar provisoriamente como sala de aula. Em pouco tempo o número de alunos chegou a quase cem, formando-se, então, duas turmas.

\footnotetext{
15 Desde o início houve preocupação em qualificar professores. Segundo Soyer (1990), o Departamento de Educação e Difusão Cultural patrocinava cursos e estágios fora de Brasília, em estabelecimentos de reconhecido valor, para os professores que trabalhavam na Novacap. Esse Departamento possuía, entre as suas funções, a responsabilidade pelo custeio da qualificação de professores.

${ }^{16}$ Informação obtida oralmente, pela autora, junto à professora pioneira, Olinda Rocha Lôbo.
} 
Após a professora Amábile Gomes Andrade, vieram para compor o primeiro corpo docente da Escola Júlia Kubitschek, as seguintes professoras: Maria do Rosário Verner, Célia Cheir, Maria de Lourdes Moreira Santos, Maria de Lourdes Cruvinel Brandão, Santa Alves Soyer, Carmem Daher e Ana Pereira Leal. Estas foram as professoras pioneiras que iniciaram a docência pública na nova Capital do Brasil.

Em face do rápido crescimento populacional e a crescente demanda por escolarização, foram sendo construídas escolas provisórias nos acampamentos de obras, em ritmo acelerado, de modo que, em 1959, antes da inauguração da Capital, já havia doze escolas primárias e dois jardins de infância em funcionamento, explicitadas na tabela a seguir.

Tabela 1 - Escolas provisórias (1957 - 1959)

\begin{tabular}{l|c}
\hline Escolas Provisórias & Instalação \\
\hline Escola Júlia Kubitschek & set./1957 \\
\hline Escola da Construtora Nacional & set./1958 \\
\hline Escola da Fundação da Casa Popular & mar./1959 \\
\hline Escola da Granja 3 - Torto & mar./1959 \\
\hline Escola do CCBE e COENGE & abr./1959 \\
\hline Escola da Metropolitana & abr./1959 \\
\hline Escola do Planalto & mai./1959 \\
\hline Escola do Ipase & mai./1959 \\
\hline Escola da Vila Bananal & mai./1959 \\
\hline Escola Granja 1 - Tamanduá & mai,/1959 \\
\hline Escola Cerâmica da Benção & ago./1959 \\
\hline Escola da Superquadra 206 & ago./1959
\end{tabular}

Fonte: DF/Departamento de Planejamento Educacional, 1984.

O canteiro de obras destinado a ser a moderna capital brasileira era um local bastante inóspito, havendo relatos abundantes sobre a poeira, clima seco e ausência de comodidade existente àquela época ${ }^{17}$, o que ressalta o caráter desbravador e pioneiro das primeiras professoras que se aventuraram a dar sua contribuição para a educação na nova capital. Em 1959, as escolas mencionadas na Tabela 1 dispunham de um total de 63 professores $\left(\right.$ NOVACAP, 1959) ${ }^{18}$.

Nessa época, não havia ônibus ou condução apropriada, somente espaços vazios e a vegetação nativa por toda parte, e as professoras enfrentavam essa situação para poderem

\footnotetext{
${ }^{17}$ Uma descrição bastante detalhada do universo feminino no período abordado por essa pesquisa encontra-se no livro/documentário: MOURÃO, de Tânia Fontenele. Poeira e batom.

${ }^{18}$ A composição do corpo docente das escolas mantidas pela Novacap, com os respectivos nomes dos professores, encontra-se no Quadro 2 desta pesquisa.
} 
lecionar. Conforme relata a professora pioneira, Maria de Lourdes Cruvinel Brandão: "Havia os 'Jeeps' da Novacap, a gente ficava em um determinado lugar esperando esses 'Jeeps' passarem e (sinal de carona) pedia condução para ir embora para as escolas. Foi mesmo uma luta, muita poeira, muita chuva. Nessa época fazia muito frio em Brasília” (BRANDÃO, 2008, p. 5).

O desafio de desbravar o cerrado e contribuir para a implantação de uma proposta educacional inovadora para a Capital Federal foi abraçado pelo grupo de professoras que para a nova capital acorreu e, como afirma a professora pioneira Santa Alves Soyer (1990), aquele grupo de professores pioneiros tinha ciência da responsabilidade que lhe fora depositada, e que se constituía em tarefa de grande vulto.

A constituição dos primeiros quadros de professoras destinadas às escolas provisórias da Novacap demandou um processo de seleção rigoroso, em que era mantida a exigência de formação mínima de normalista para o ingresso no magistério. Conforme depoimento da professora Santa Alves Soyer (1990),

\begin{abstract}
A seleção de professores para as escolas mantidas pela Novacap tem sido feita através de estágios realizados no Grupo Escolar Júlia Kubitscheck em 1958 e 1959. É condição fundamental a apresentação de diploma de curso normal. Os estágios constaram de aulas práticas nas diversas séries do curso, com observação feita por comissão de professores para tal fim designada. Preenchendo as condições morais e pedagógicas exigidas, a candidata tem sido aproveitada após algum tempo de caráter experimental (p. 49).
\end{abstract}

Registre-se que essa seleção era realizada pela Escola Júlia Kubitschek, primeira escola pública do Distrito Federal, inaugurada em 1957, e embrião da experiência da educação inovadora que se pretendia implantar na nova Capital. Essa instituição tornou-se referência para a educação em Brasília, em termos de organização escolar e prática pedagógica, conforme será exposto no próximo item.

No que tange à seleção de professores para as primeiras escolas, cabe ainda mencionar que, ladeada a exigência de formação inicial, havia também preocupação no sentido de assegurar que os docentes estivessem aptos a desenvolverem as suas atividades pedagógicas de forma compatível com a proposta formulada para a educação brasiliense, cujos princípios, baseados na filosofia da Escola Nova, previam uma nova postura e preparo adequado de seus professores. 
Até o início de 1960 já havia dezesseis escolas e sessenta e seis professores, sendo que a coordenação dessas escolas era feita pela professora Santa Alves Soyer ${ }^{19}$, que também era responsável pela implantação de novos estabelecimentos de ensino quando do surgimento das cidades satélites $^{20}$. A referida professora relata como fazia o acompanhamento dessas escolas:

Como é que eu conseguia... organizar essas dezesseis escolas que já existiam? De início eu tinha um caminhão - o zelador da Escola $n^{\circ} 01$, da qual eu era diretora, 'seu' Antônio, era, ao mesmo tempo zelador e meu motorista. Então aqui... surgia, assim, de um dia para o outro um novo acampamento, uma nova vila de operários. E os engenheiros comunicavam à Novacap a necessidade de construção de barracos, de alojamentos, e da escola. E eu era chamada para ir com um engenheiro escolher o local onde eles fariam a escolinha de madeira logo em seguida. De um dia para o outro ficava pronta. E eu ia de caminhão, e assim eu trabalhei até o início de 1960, quando então me deram um jipe. Trabalhava de caminhão. Colocava um avental, um lencinho na cabeça e ia por aí fundar escolas, todas essas escolas, zona rural, enfim... passava o dia fora (SOYER, 1990, p.29).

No ano de 1960, diante da iminência da inauguração de Brasília e do início de funcionamento das escolas criadas nos moldes propostos pelo educador Anísio Teixeira ${ }^{21}$, tornou-se imprescindível a ampliação do quadro docente. Dada a importância de selecionar professores qualificados e dispostos a contribuírem com a implementação da proposta educacional inovadora da nova Capital, então, como uma das primeiras atribuições da Comissão recém criada - Comissão de Administração do Sistema Educacional de Brasília Caseb, promoveu-se concurso para o magistério em nível nacional.

O concurso foi amplamente divulgado por todo o país. Com essa seleção desejava-se a formação de uma equipe com novo espírito e consciência pedagógica capazes de fazer a educação inovadora almejada para a nova Capital. Segundo o diretor executivo da Caseb, professor Armando Hildebrand, em resposta a esse apelo, acorreram várias pessoas "que deixaram posições boas em seus Estados e vieram para a nova jornada, nova experiência, nova ação no campo do ensino, como grandes idealistas" (PEREIRA, et. al, 2011, p. 183).

\footnotetext{
19 A professora Santa Soyer permaneceu à frente da Coordenação do Ensino Primário, atuando como coordenadora do Ensino Primário até $1^{\circ}$ de março de 1961, quando foi substituída nesta função pela professora Helena Reis. A atuação dessas coordenadoras consistia em prestar orientação pedagógica às escolas e aos professores.

${ }^{20}$ Foi uma designação utilizada para se referir aos centros urbanos surgidos nos arredores de Brasília, sendo essa a cidade núcleo do Distrito Federal. Atualmente são denominadas de Regiões Administrativas.

${ }^{21}$ Note-se que fazia parte do planejamento da Nova Capital construção de complexa organização escolar idealizada por Anísio Teixeira, no Plano de Construções Escolares de Brasília, O primeiro conjunto escolar, composto por escola classe, escola parque e jardim de infância, situado à Super Quadra 308 Sul do Plano Piloto, foi inaugurado pelo Presidente Juscelino Kubitschek juntamente à inauguração da Capital, em 21 de abril de 1960.
} 
Visando atrair profissionais qualificados de todo o País, foram elaboradas duas cartas circulares $^{22}$, acompanhadas de formulários, conclamando professores para se inscreverem no concurso (DISTRITO FEDERAL, 1984). A primeira carta destinava-se aos professores do ensino elementar ${ }^{23}$ e a segunda era dirigida aos professores de ensino médio. Dado o objeto desta pesquisa, tratar-se-á apenas da carta endereçada aos professores da escola elementar.

Dessa carta constavam informações relativas ao salário, à natureza do contrato em relação às leis trabalhistas, do compromisso de que os professores selecionados receberiam passagens para si e para a família, com a finalidade de deslocarem-se para a Capital Federal, além de ajuda de custo para sua instalação, direito à residência por meio de pagamento de aluguel acessível e ensino primário e médio gratuitos aos seus filhos (DISTRITO FEDERAL, 1984, p. 33). Formulário anexo a essa carta apresentava os critérios estabelecidos para a seleção. Além da exigência de aprovação na prova escrita, o candidato deveria submeter-se à entrevista, baseada nas informações prestadas previamente pelo candidato, mediante preenchimento do formulário, em relação à sua formação e experiência profissional. A entrevista era realizada por psicólogos, primeira experiência do gênero ocorrida no país, segundo explicitado no Relatório Quinquenal (MEC, 1956-1960). Havia, ainda, a exigência de três referências relativas à sua idoneidade e experiência profissional, assim como de explicitação das razões pelas quais teria optado por exercer a função docente em Brasília. Destaque-se que eram muitas as vantagens para o ingresso de professores no sistema público de educação da nova Capital, tornando-se uma proposta bastante atrativa ${ }^{24}$.

A realização desse concurso público foi abraçada pela equipe gestora da construção da cidade e destinava-se a professores de todo o país, que tivessem ânimo a deixar sua localidade de origem, para participar da construção do novo modelo educacional proposto para Brasília (VIEIRA, 1990).

$\mathrm{Na}$ busca por docentes mais qualificados, a referida equipe deslocou-se do Planalto Central e dirigiu-se ao Centro Brasileiro de Pesquisa Educacional, no Rio de Janeiro, local de formação do magistério, para divulgar o concurso entre os docentes que realizavam cursos de especialização nesse Centro. Com esse intuito, foram promovidas palestras, que contaram

\footnotetext{
${ }^{22}$ A carta circular referente ao grau elementar encontra-se no anexo desta dissertação. O concurso para esse nível de ensino destinava-se ao preenchimento de vagas de professores primários e de jardim de infância.

${ }^{24}$ Algumas das condições prometidas na carta circular não se cumpriram, fato relatado por diversas professoras em suas entrevistas, a exemplo das promessas relativas à moradia e creche que não foram atendidas; o que levou os docentes recém-contratados a desencadearem movimentos de protesto, inclusive realizando a primeira greve do magistério em Brasília (PEREIRA, et. al. 2011).
} 
com a participação de Oscar Niemeyer, Ernesto Silva, Armando Hildebrand, entre outras personalidades que, de alguma forma, estavam envolvidas com o plano educacional de Brasília. Na condição de representantes do Inep, os palestrantes expuseram o planejamento urbanístico da cidade em construção, seu projeto futurístico e as vantagens dos professores se deslocarem para a nova Capital, tais como: suporte técnico especializado, salário superior a todas as unidades da federação, benefício de moradia e creche para filhos pequenos. Para facilitar a participação de maior número de candidatos, houve a possibilidade de realizar a prova nos respectivos estados de origem.

A professora Alita Vieira (1990), procedente do Paraná, em seu depoimento relata que fazia estágio no CBPE/RJ, no ano de 1959, quando tomou conhecimento do citado concurso, por meio das falas entusiasmadas dos palestrantes. Decidiu, então, participar da seleção, tendo logrado aprovação e classificando-se em primeiro lugar.

Em suma, conforme avalia Pereira (2011), tratou-se- de uma rigorosa seleção com base em critérios que englobavam titulação, entrevista e prova prática, que resultou numa taxa de reprovação de $40 \%$ dos candidatos inscritos. Foram aprovados educadores provenientes das várias regiões do país, que se somaram à equipe inicial de docentes, constituindo, assim, um grupo representativo da diversidade brasileira.

\subsection{A primeira escola pública da Nova Capital — orientação e supervisão do Inep}

A Escola Júlia Kubitschek - primeira escola pública do Distrito Federal -, construída em 1957, surge da necessidade emergencial de atendimento às crianças em idade escolar. Situada na Candangolândia, acampamento formado pelos primeiros moradores de Brasília, onde se localizavam os galpões da Novacap, instituição responsável pela construção da Capital Federal. Essa escola constituiu-se o embrião da proposta educacional de Anísio Teixeira. Sua importância decorre tanto do seu projeto arquitetônico como da sua configuração pedagógica. Obra de Oscar Niemeyer, a sua construção em madeira assemelhava-se ao Palácio do Catetinho, então residência oficial do Presidente da República, o que levou a comunidade local a denominá-la de "Catetinho da Educação". Do ponto de vista pedagógico, a escola inovou, à luz do ideário que fundamentou o plano de educação da nova Capital, tendo em vista proporcionar aos alunos atividades diversificadas, de cunho teórico e prático, que rompiam com o modelo escolar tradicional existente à época. É possível perceber, em seu planejamento e constituição, a conformidade com as ideias de Anísio Teixeira (PEREIRA; HENRIQUES, 2011), que defendia a escola como formadora do sujeito 
integral, não apenas de letras, ou de iniciação intelectual sistemática. Nesse sentido, Anísio afirmava que

[...] Ler, escrever, contar e desenhar serão por certo técnicas a ser ensinadas, mas como técnicas sociais, no seu contexto real, como habilidades, sem as quais não se pode hoje viver. O programa da escola será a própria vida da comunidade, com o seu trabalho, as suas tradições, as suas características devidamente selecionadas e harmonizadas (TEIXEIRA, 1957, p. 50).

A jornada escolar da Escola Júlia Kubitschek era de dois turnos, com aproximadamente sete horas em cada um. As crianças faziam três refeições na escola, sendo que a alimentação era de responsabilidade do Serviço de Alimentação da Previdência Social SAPS. Os alunos recebiam, também, auxílio financeiro para compra de uniforme e material escolar. Esse se dava não apenas por motivos financeiros, mas também por dificuldades de acesso aos mesmos em virtude do comércio ainda incipiente (PEREIRA; HENRIQUES. In PEREIRA, 2011).

A equipe de docentes da Escola Júlia Kubitscheck passou a ter a responsabilidade pela seleção dos novos professores que vieram a compor o quadro do magistério das escolas mantidas pela Novacap. O processo para escolha das professoras era bastante rigoroso. Esse rigor, descrito no depoimento da professora Santa Alves Soyer, mostra que "a admissão das professoras se dava por um difícil processo em que a candidata deveria ministrar uma aula para cada uma das séries, sendo avaliada pelas professoras já efetivas e depois que eram admitidas ainda ficavam uma semana sob observação." (SOYER, 1990, p. 14).

Tal modo de admissão resultou na composição de um grupo caracterizado por seu nível técnico e compromisso com a educação. Como se verificou, algumas professoras possuíam, já no momento de ingresso, especialização em áreas diversas, como Maria de Lourdes Ávila de Bessa, formada pelo Instituto de Educação de Belo Horizonte no Curso de Formação de Professores Primários; Maria das Neves Costa Morici, também especializada em alfabetização; Maria de Lourdes Cruvinel Brandão, professora de música, Maria Helena Parreira, professora de artes e Dalva Baptista Obliziner, especializada em Artes Industriais mediante curso realizado no SENAI, São Paulo. As duas últimas foram transferidas para a Escola Parque após sua inauguração, em 1960.

Foram matriculados, inicialmente, na Escola Julia Kubtischek, 150 alunos. Porém, o crescente aumento populacional da Capital em construção deu origem a uma grande demanda por escolarização. Assim, ao final de dois anos, em 1959, esse quantitativo era de 2.134 alunos (NOVACAP, 1959), conforme pode ser observado na Tabela 2, a seguir. Havia norma 
expressa da Novacap de matricular todas as crianças. As crianças ingressavam no decorrer do ano letivo, conforme sua chegada à cidade. Segundo os depoimentos de professoras pioneiras $^{25}$, havia um espírito de voluntarismo e o desejo de que todos os alunos aprendessem.

Tabela 2 - Evolução de matrículas no ensino elementar do Distrito Federal

\begin{tabular}{c|c|c|c|c}
\hline Anos & Alunos & Escolas Primárias & Jardins de Infância & Professores \\
\hline 1957 & 150 & 01 & 0 & 05 \\
\hline 1958 & 626 & 02 & 1 & 18 \\
\hline 1959 & 2.134 & 12 & 2 & 67 \\
\hline
\end{tabular}

Fonte: Novacap. A Educação Primária em Brasília. 1959

A princípio a organização das classes era feita segundo a idade cronológica, sendo que as crianças ainda não alfabetizadas eram submetidas ao teste $\mathrm{ABC}$, de autoria de Lourenço Filho, cujo critério de agrupamento era a maturidade da criança. (SOYER, 1990, p. 23). Os dados indicam que a maioria dos alunos constituía as classes de alfabetização, sendo considerável o número de crianças defasadas em relação à idade/série, conforme ilustra a Tabela 3, a seguir.

Tabela 3 - Quantitativo de alunos com 11 anos - por série

\begin{tabular}{c|c}
\hline Série & Quantitativo de alunos \\
\hline $1^{\text {a }}$ Série & 75 \\
\hline $2^{\text {a }}$ Série & 40 \\
\hline $3^{\text {a }}$ Série & 23 \\
\hline TOTAL & $\mathbf{1 3 8}$ \\
\hline
\end{tabular}

Fonte: Novacap. A Educação Primária em Brasília. 1959

As dificuldades encontradas no processo de alfabetização das crianças são relatadas em depoimentos de professoras pioneiras, que afirmam o seu compromisso com os pressupostos teórico-filosóficos propostos para as escolas da nova Capital, alegando, porém, que não havia uma imposição quanto às metodologias a serem adotadas para o processo de aquisição da leitura e escrita. Um dos relatos destacados é da professora Maria do Rosário

\footnotetext{
${ }^{25}$ Entre as professoras pioneiras entrevistadas, citem: se: Amábile Gomes Andrade, Dalva Batista Obliziner, Maria das Neves Costa Morici, Maria do Rosário Bessa, Santa Alves Soyer e Olinda Rocha Lôbo.
} 
Ávila de Bessa, que veio de Belo Horizonte para Brasília em meados de 1957, acompanhando seu esposo, responsável pela instalação do serviço jurídico na Novacap. À época, ela contava com vinte três anos de idade e iniciou o trabalho com uma turma de alfabetização. Segundo relata, as crianças não eram muito fáceis de serem alfabetizadas pela ausência de um ambiente doméstico favorável à alfabetização, em termos de experiências, convívio familiar e cultural (BESSA, 2008), embora revele ter realizado um trabalho proveitoso. A mencionada professora informa que eram

[...] utilizados o método eclético, o método silábico, como (se) achasse melhor. [...], naquela época, não havia uma imposição. Depois é que nós fizemos (o currículo) eu fui trabalhar com a Ana Bernardes, lá na coordenação do primário, a Ivonilde, e mais outras [...] a Norma, a Maria Alice, [...] Nós fizemos o currículo para a escola primária. (BESSA, p. 27).

Como todas as professoras selecionadas possuíam experiência com a educação primária, nesse início cada uma trabalhava conforme suas experiências anteriores, no tocante a aquisição da leitura e escrita. Embora o método fosse livre, o que pode passar a falsa ideia de que não havia coordenação entre o grupo, este se reunia constantemente em reuniões e discussões de estudo, a fim de que estivessem em acordo com o plano de educação previsto para a nova Capital.

A professora Maria do Rosário Ávila de Bessa relata, também, que em sua prática docente, utilizava-se de diferentes recursos pedagógicos, conforme descrito a seguir:

[...] consegui fazer uma espécie assim de uma lojinha, em que eu simulava... tinha lápis, tinha caderno, tinha borracha... mas tudo assim, não para vender mesmo, porque nós não tínhamos nem dinheiro para isso. Então, nós simulávamos a venda e fazíamos, todo dia, um caixa: o que entrava e o que saía. Era muito interessante. E eles faziam direitinho. Eu fiquei muito impressionada, foi uma das experiências que mais me impressionaram, porque eles faziam tudo direitinho (BESSA, 2008, p. 5 e 6).

Tais ações demonstram a consonância entre o trabalho desenvolvido na Escola Júlia Kubitschek e os pressupostos da escola renovada, cuja ênfase recai sobre a ação da criança, de sua vivência em situações da vida prática e na aquisição de conhecimentos que promovam a inserção da escola à vida sociocultural da criança.

Apesar dos percalços relatados, é possível se observar o empenho com que se buscava o sucesso escolar dos alunos. Havia uma grande vontade de fazer dar certo, de forma que o esforço de todas as professoras se somava no intuito de se buscar a melhor forma para que as crianças alcançassem uma aprendizagem satisfatória. As adversidades avolumavam-se: alunos 
matriculados ao longo do período escolar, crianças defasadas em relação à idade/série escolar e, ainda, o desafio de ensinar crianças procedentes das diversas regiões brasileiras, portadoras de cultura bastante diversificada.

As dificuldades encontradas pelas docentes de Brasília não representam caso isolado, pelo contrário, demonstravam a realidade do ensino primário nacional. Fato constatado pelos órgãos vinculados ao Ministério da Educação que gerou demanda por meio de ações específicas, como se pode verificar a seguir.

No Relatório Quinquenal (MEC, 1960, p. XVII) há detalhamento das ações desenvolvidas no âmbito educacional entre 1955 a 1960. Após "minuciosa análise das deficiências quantitativas e qualitativas do ensino, em todos os graus e ramos", o documento aponta as metas esperadas e faz recomendações para o alcance do "aperfeiçoamento do sistema de ensino brasileiro".

A respeito das deficiências encontradas em 1957, em relação ao ensino primário, o referido documento aponta:

- Desordem nas matrículas em função da correspondência entre a idade mental e as respectivas séries escolares;

- Desordem na composição das classes pela reunião de grupos heterogêneos: carência seletiva dos recém- ingressos; permanência de repetentes; rígidos critérios de promoção;

- Desordem na distribuição dos horários, pela atual necessidade de manter a escola, simultaneamente, essas classes e atender ás crescentes solicitações de matrículas, em dois e três e quatro turnos diários prejudiciais ao ensino (MEC, 1960, p. XXXVII).

Visando a superação das disfunções apontadas, o Ministério da Educação propôs as metas que se seguem:

- Graduação da escola pela idade do aluno;

- Adoção de regime mais flexível de promoções;

- Extensão gradativa do dia escolar até 6 horas;

- Extensão da escolaridade a seis anos nas áreas urbanas e a quatro anos nas zonas rurais;

- Campanha Nacional e erradicação do Analfabetismo (MEC, 1960, p. XXXVIII). 
Pela análise do rol de metas determinadas pelo Ministério da Educação visando sanar os problemas encontrados no sistema educacional brasileiro, detecta-se que as mesmas se encontram nos princípios educativos estabelecidos para a nova Capital Federal. Assim, na descrição do trabalho empreendido inicialmente na Escola Júlia Kubitschek e seguido pelas demais escolas que foram surgindo, nota-se a coerência com os parâmetros almejados para a Federação, observados, desde o princípio na nova Capital.

Depoimento da professora Amábile Gomes Andrade ilustra o perfil requerido das professoras da Escola Júlia Kubistchek, em face da diversidade da constituição do corpo discente, uma vez que as crianças eram provenientes de todos os estados brasileiros, e, ainda, de representações diplomáticas de outros países. Nas palavras da referida professora: "Eu tive aluno índio, eu tive aluno grego, aluno espanhol, gente que mal sabia... aprendendo a falar português" (ANDRADE, 2002, p. 15).

Essa escola, que funcionava em uma construção de madeira, diversa dos modernos modelos arquitetônicos planejados para as escolas-classe que mais adiante iriam compor o sistema educacional de Brasília, desempenhou um papel relevante na história da educação da nova Capital, seja por sua filosofia e suas práticas pedagógicas, seja pela competência e dedicação de seus professores. A professora pioneira Olinda da Rocha Lôbo descreve suas impressões ao visitar essa escola pela primeira vez, referindo-se a ela como tendo "estrutura bem aberta, cheia de flores...tinha jardim, tinha piscina para a criança, a criança ficava o dia todo, almoçava...eu achei muito interessante...fiquei encantada...” (LÔBO, 2001, p. 13)

Organizada sob a forma de uma comunidade de trabalho e vida, a Escola Júlia Kubitschek desenvolvia um currículo composto pelas disciplinas tradicionais, português, matemática, ciências, história e geografia e, ainda, por atividades complementares de trabalho e de caráter social, como iniciação musical, artes plásticas, educação física e cultivo de horta. Esse currículo estava em consonância com os princípios da educação nova defendidos no Plano de Construções Escolares de Brasília, que apontava a escola como formadora do sujeito integral, detentor não apenas de conhecimento intelectual, mas, também de conhecimentos da vida prática que lhe proporcionassem a condição de exercer plenamente a sua cidadania (TEIXEIRA, 1957).

Nesse mesmo sentido, ao observar os princípios educativos arrolados no Relatório Quinquenal do MEC (MEC, 1960) nota-se que o sistema educacional implantado na nova Capital encontra-se em harmonia com os mesmos, quais sejam: 
[...] a teoria educacional que fundamenta o trabalho nessa escola parte dos seguintes princípios: a aprendizagem, por ser mais importante que o ensino, constitui o núcleo ao redor do qual gira toda a vida escolar; não há aprendizagem real sem esforço mental, sem participação do pensamento, sem atos inteligentes; a aprendizagem depende entre outras coisas, da qualidade das experiências planejadas e realizadas pelas crianças; as experiências de maior poder educativo são as que têm significação para o aluno e que o conduzem naturalmente a outras iniciativas; as diferenças individuais são reconhecidas e impõem ao mestre uma nova atitude de trabalho; a cooperação, iniciativa, o espírito de ordem e disciplina não são de caráter geral, especificamente vinculados às atividades executadas pelas crianças. (MEC, 1960, p. 215 e 206).

Assim, na prática, o ordenamento desses princípios ocorre por meio da ação educativa e na forma intensa com que as crianças vivem na escola. Participando ativamente do planejamento das atividades que irão fazer, há grande possibilidade de cooperação de todos, por terem um objetivo em comum, e, ainda, pela disposição dos grupos feita de acordo com as idades. A proximidade entre as crianças não se dá apenas pela coexistência: há convívio, troca de experiências, brincadeiras, trabalho e auxílio recíproco (MEC, 1960). Ilustrando-se o trabalho coletivo dos alunos, estimulado a partir de diferentes situações didáticas, cabe mencionar a publicação de jornalzinho pela turma de terceira série, da Escola Júlia Kubitscheck, em 1958. Intitulado "A Voz do estudante“, esse jornalzinho tinha a função de divulgar as notícias do universo escolar, em forma de pequenos artigos elaborados pelas crianças (DF, 1984, p. 21).

Note-se que a qualificação de professores se revestia da maior importância, se constituindo em condição sine qua non para o sucesso da experiência pedagógica cujo propósito seria a formação integral da criança e sua plena cidadania. Nesse sentido, a Escola Júlia Kubitschek contou, desde o início, com a orientação e supervisão técnica do Inep, que, para essa finalidade, designou os especialistas Paulo Campos de Almeida e Nair Durão Barbosa Prata.

Na estrutura do Inep, a Divisão de Aperfeiçoamento do Magistério - DAM, juntamente com o CBPE eram os executores das ações para o magistério primário, e as professoras pioneiras, desde o princípio, foram inseridas nas ações promovidas por esse órgão, incluindose estágio em Salvador, Bahia, que será detalhado no próximo item. A participação do professorado nas iniciativas de formação oferecidas pelo Inep realizou-se nos Centros Regionais de Pesquisas Educacionais - CRPEs, em vários estados da Federação. O critério básico para participação consistia na relação do curso com a área de atuação do professor. 
A análise de depoimentos de professoras pioneiras que atuaram na Escola Júlia Kubitschek indica que os referidos técnicos prestavam orientação sistemática à equipe docente com base nos fundamentos teórico-filosóficos preconizados pelo ideário da Escola Nova. A partir das orientações recebidas, as professoras planejavam e operacionalizavam as ações pedagógicas, levando em conta a realidade em que se encontravam inseridas. Tal postura se coaduna com a filosofia de educação dotada pelo citado Instituto, segundo a qual o professor deixa de ser mero transmissor de conhecimento para tornar-se pesquisador, que investiga e promove a cultura local. Essa tarefa do docente requer "o melhor conhecimento possível da criança e o melhor conhecimento possível da vida e de suas exigências" (TEIXEIRA, 1967, p. 246-253).

Observe-se que, num primeiro momento, não havia na escola um currículo préestabelecido. Assim, contando com a orientação técnica do Inep, as professoras com experiências docentes anteriores adequavam a sua prática pedagógica às circunstâncias então existentes, conforme relata em seu depoimento a professora Santa Alves Soyer:

Nós adaptávamos o currículo de ensino elementar à região e à situação da escola. Que tipo de problema nós queríamos resolver? Era o ensino, o ensino de primeiro grau, o ensino primário [...] Porque nós estávamos em uma cidade em formação, na construção de uma cidade. Então, tinha que ampliar esse currículo dentro daquilo que as crianças estavam vivendo, daquele momento. Elas estavam participando, vendo quando eles iam abrir um local para construir um prédio, elas viam os edifícios, os palácios que estavam sendo construídos. Faziam excursões e anotava-se aquilo que eles viam. Quer dizer, o currículo estava sendo adaptado também ao momento, não é? (SOYER, 1990, p. 22 e 24) ${ }^{26}$

Cite-se ainda o depoimento da professora Stella dos Cherubins Guimarães Trois, em que afirma ter sido muito rica a experiência vivenciada com a implantação do sistema educacional de Brasília, uma vez que cabia às professoras pioneiras "estabelecer as linhas de interpretação do plano de Anísio Teixeira e construir a operacionalização desse plano. "Foi muito rico porque foi um desafio, não havia uma receita, um modelo para se fazer." (TROIS, 1990, fita 1-B).

Dedicava-se especial atenção para as atividades de planejamento e de estudo. Segundo a professora Dalva Batista Obliziner (OBLIZINER, 2003), havia muito envolvimento e participação no desenvolvimento do trabalho pedagógico, sendo que as professoras realizavam um planejamento bem estruturado, em conformidade com a proposta de Anísio

\footnotetext{
${ }^{26}$ Somente nos anos 1961/1962 foi designada uma equipe, formada por professores de cada área, para realizarem estudos e organizarem o currículo, mediante financiamento do MEC.
} 
Teixeira. As atividades com as crianças ocorriam durante seis horas diárias e as outras duas, destinavam-se aos trabalhos de coordenação.

Além do processo de qualificação profissional que se dava dentro da própria escola, mediante trabalho coletivo e assistido na coordenação pedagógica, a partir de 1959, com a criação da Comissão de Administração do Sistema Educacional de Brasília - Caseb $^{27}$, os professores primários participaram de cursos promovidos por essa instituição, via de regra, realizados durante o período de férias escolares.

Consulta às fontes da pesquisa revelam que, no aludido período, os docentes tiveram oportunidade de realizar uma variedade de cursos de aperfeiçoamento profissional. Embora esta pesquisadora não tenha localizado documentos oficiais sobre os cursos oferecidos pela Caseb, depoimentos de docentes atuantes naquele período mencionam as ações de formação promovidas por essa instituição. É o que se constata no depoimento da professora Maria das Neves Costa (MORICI, 2001), ao relatar a sua participação em diversos cursos promovidos pela Caseb, qual sejam: de recreação, jogos infantis, orientação para o ensino elementar, didática para professores primários, recursos audiovisuais para o ensino elementar e aperfeiçoamento de linguagem, entre outros.

Conforme afirma a mencionada professora, o diretor da Novacap para as áreas de educação e saúde, Dr. Ernesto Silva, era muito cuidadoso com o desempenho dos professores e se empenhava para que o corpo docente estivesse permanentemente atualizado. Na sua percepção, as professoras primárias dedicavam especial atenção para as atividades de planejamento e de estudo. Designada, posteriormente, para trabalhar na Caseb, a professora informa sobre a preponderância da oferta de cursos em didática, além de outros, abrangendo diferentes áreas de conhecimento (MORICI, 2001).

Após a inauguração de Brasília, a responsabilidade pela área de educação é transferida da Novacap para a Fundação Educacional do Distrito Federal ${ }^{28}$, que deu continuidade às ações voltadas à qualificação docente. Essa incumbência ficou a cargo do Departamento de Ensino Elementar, sob a direção da professora Helena Reis, cujas iniciativas são destacadas por professoras pioneiras: "esse Departamento realizou um trabalho muito bom, porque a dona Helena procurava promover o professor, o trabalho do professor, era muito bem

\footnotetext{
${ }^{27}$ A Comissão de Administração do Sistema Educacional de Brasília foi criada por meio do Decreto $\mathrm{n}^{\circ} 47.472$, de 22 de dezembro de 1957, do Ministério de educação e Cultura, tendo por finalidade organizar e administrar o ensino primário e os ensinos de grau médio em Brasília, como também incrementar as atividades culturais na nova capital.

${ }^{28}$ A Fundação Educacional do Distrito Federal foi criada em 17 de junho de 1960 por meio do Decreto Presidencial $n^{\circ} 48.297$, assinado pelo presidente Juscelino Kubitschek.
} 
orientado [...] Promovia cursos, seminários, palestras, tudo em função disso" (SOYER, 1990, p. 33).

Como se pode constatar, além da preocupação com a formação inicial dos professores ingressantes, explicitada nos critérios de seleção para o seu ingresso no sistema educacional da nova Capital, houve também o cuidado em oferecer condições para o aperfeiçoamento docente ao longo de sua atuação profissional. Documentos oficiais e depoimentos analisados informam que o Departamento de Ensino Elementar patrocinava cursos e estágios aos docentes, realizados, em grande parte, mediante parceria com o INEP, como será descrito nos itens seguintes.

\subsection{Estágio em Salvador: Os professores pioneiros conhecem a Escola Parque da Bahia}

Buscando qualificar o ensino sob sua direção e responsabilidade, o Departamento de Educação e Difusão Cultural, vinculado à Novacap, promoveu estágios e cursos intensivos em instituições de renomada qualidade educativa. Assim, ao principiar as atividades docentes, em abril de 1958, as primeiras professoras da Escola Júlia Kubistchek foram enviadas a Salvador, Bahia para realizar estágio no Centro Educacional Carneiro Ribeiro, com o propósito de conhecer o funcionamento das escolas classe e escola parque e se familiarizarem com o modelo escolar similar ao do sistema com o qual iriam trabalhar (NOVACAP, 1959).

Segundo a fonte consultada, nos anos seguintes, novos grupos de professoras realizaram o estágio no mencionado Centro Educacional, na Bahia, conforme explicitado na tabela a seguir.

Tabela 3 - Estágios de professores em Salvador/Bahia

\begin{tabular}{c|c|c}
\hline Ano & Quantitativo de Professores & $\begin{array}{c}\text { Duração do } \\
\text { Estágio }\end{array}$ \\
\hline 1958 & 10 professoras & 20 Dias \\
\hline 1959 & 12 professoras & 8 dias \\
\hline 1960 & 8 professoras & 3 meses \\
\hline
\end{tabular}

Fonte: Novacap. A Educação Primária em Brasília. 1959

Conforme se constata pela Tabela 4, o primeiro e o terceiro estágios tiveram maior duração, gerando o afastamento das professoras de Brasília por vinte dias, no caso do primeiro estágio, e de três meses, no terceiro. Esse afastamento gerou dificuldades pessoais para algumas delas, por serem casadas e ainda jovens com filhos pequenos, que tiveram de 
reorganizar sua vida em função dessa viagem. Foi o que ocorreu com a professora Maria do Rosário Ávila de Bessa (BESSA, 2008), que, para realizar o estágio, teve de enviar sua filha pequena para a casa dos avós, em Belo Horizonte.

No ano de 1958, realizaram estágio em Salvador ${ }^{29}$, as professoras pioneiras Amábile Gomes Andrade, Ana Leal Costa, Maria Helena Parreira, Maria de Lourdes M. Santos, Maria do Rosário Ávila de Bessa e Santa Alves Soyer. Já o estágio realizado em 1959 contou com a participação das professoras Célia Sheyer, Delza Guimarães, Helena Lopes de Melo, Irmã Nisa, Julieta Gonçalves dos Reis, Maria Antônia Jacinto, Maria Isaura e Olinda Rocha Lôbo. O terceiro estágio iniciou-se em setembro de 1960, e teve duração de três meses. Consta em relatório do Inep a informação de que este foi patrocinado pela Novacap (INEP, 1960).

Esses estágios visavam preparar os professores para a implantação do sistema educacional inovador da nova Capital, especialmente em relação ao funcionamento das escolas classes e escola parque. Os dois primeiros estágios qualificaram as docentes para atuação nas escolas classe, ao passo que o terceiro visava prepará-las para o trabalho complementar em artes, educação física e diferentes modalidades de artes industriais, que seria desenvolvido na Escola Parque. O quadro a seguir apresenta a relação de cursistas e respectivas áreas de especialização.

Quadro 1 - Terceiro Estágio realizado na Escola Parque de Salvador/BA- 1960

\begin{tabular}{|l|l|}
\hline \multicolumn{1}{|c|}{ Professoras } & \multicolumn{1}{c|}{ Área de especialização } \\
\hline Antônia Paczkoski & Couro, tapeçaria e encadernação \\
\hline Delcy Aguiar & Cartonagem, corte e costura, tapeçaria \\
\hline Elza Alves da Cunha & Corte e costura, tecelagem e cestaria \\
\hline Leocácia Paradella Toscano & Tecelagem, metal, modelagem e couro \\
\hline Maria Helena Fúrio & Metal, madeira, cerâmica e desenho \\
\hline Maria Helena de L. Tôrres & Tecelagem, feltro e couro \\
\hline Maria Helena Parreira & Desenho, estamparia e cerâmica \\
\hline Maria Isaura de A. e Silva & Cestaria, tapeçaria e couro \\
\hline
\end{tabular}

Fonte: Novacap. A Educação Primária em Brasília. 1959.

\footnotetext{
${ }^{29}$ Embora na busca realizada nos arquivos do Inep esta pesquisadora não tenha logrado localizar informações mais detalhadas sobre os docentes de Brasília que participaram dos dois primeiros estágios em Salvador, levantamento realizado a partir dos relatórios mencionados, de depoimentos de professoras e outros documentos permitiu identificar a maioria das professoras participantes dos referidos estágios.
} 
Conforme descrito nos relatórios dos dois primeiros estágios, as docentes de Brasília, ao chegarem a Salvador, foram recepcionadas pela professora Carmem Teixeira, irmã do educador Anísio Teixeira, que atuava simultaneamente como supervisora dos cursos promovidos pelo Centro Regional do Instituto Nacional de Estudos e Pesquisas Educacionais, CRINEP, e como diretora da Escola de Aplicação do Centro Educacional Carneiro Ribeiro. A sua presença permanente no decorrer das atividades promovidas ao longo dos estágios representou uma especial deferência aos professores, em face da sua relevância na implantação do plano educacional na futura Capital $^{30}$.

O acompanhamento da professora Carmem Teixeira é mencionado no Relatório de Estágio (1959) elaborado por participantes do segundo grupo, que informa sobre atividades realizadas nos dias 9, 10 e 11/09/1959 pelas professoras de Brasília. Nessa ocasião, ao realizarem trabalho de observação na escola experimental do Centro Educacional Carneiro Ribeiro, o grupo foi acompanhado pela educadora supramencionada, que esteve durante todo o tempo, "prestando orientações e auxiliando-as a fim de que o estágio fosse proveitoso" (Relatório de Estágio, 1959, p. 2).

Os estágios tiveram início com palestra proferida pela professora Carmem Teixeira versando obre os princípios básicos do Centro Educacional Carneiro Ribeiro, enfatizando que as ações docentes deveriam centrar-se nas crianças e não nos interesses dos adultos, assim como a aprendizagem basear-se na intenção de aprender da criança e não na intenção de ensinar do professor.

Consta dos relatórios referentes aos estágios realizados em 1958 e 1959, anteriormente mencionados, que a programação desses estágios se desenvolveu em tempo integral, de forma intensiva, constituindo-se de atividades de observação no Centro Educacional Carneiro Ribeiro. As professoras de Brasília visitaram todos os espaços educativos que compunham esse estabelecimento de ensino: Escola Parque, Escolas Classe, Escola de Aplicação e Jardim de Infância, sendo sempre assistidas pela professora Carmem Teixeira e pelos coordenadores responsáveis por cada setor visitado.

\footnotetext{
${ }^{30}$ Consta do Relatório de estágio (1958) que o primeiro grupo de professoras de Brasília visitou a sede do Governo do Estado, tendo sido recebido pelo próprio governador.
} 
Os relatórios de estágio informam sobre os múltiplos espaços do Centro Educacional Carneiro Ribeiro observados pelas docentes de Brasília, quais sejam: Biblioteca Monteiro Lobato, Fórum Rui Barbosa, Escolinha de Artes Plásticas, Museu Histórico e Jardim Zoológico. Tais espaços eram constituídos à semelhança de organizações que compõem a sociedade e eram nominados internamente de instituições. Em seu conjunto, buscava-se simular uma cidade em miniatura, chamada de Cidade da Alegria, na qual as crianças desenvolviam atividades destinadas à socialização e ao aprendizado experiencial relativo ao funcionamento das diversas instituições que compõem a vida urbana, como cartório de registro civil, tipografia, livraria, biblioteca infantil, agência bancária, supermercado, zoológico etc. A organização e administração desses espaços competiam às crianças, sob a supervisão dos seus professores, ensejando situações de aprendizagem que favoreciam aos alunos a compreensão do caráter social de cada uma destas instituições.

Os citados relatórios destacam que as ações desenvolvidas nesses espaços possuíam cunho social e pedagógico, objetivando tanto o desenvolvimento de habilidades sociais, como também a aprendizagem de conteúdos curriculares. As vivências dos alunos em cada setor da Cidade da Alegria possibilitavam a aprendizagem simultânea nas diversas áreas de conhecimento, de cunho prático, a exemplo da linguagem escrita, mediante a confecção e exposição, pelas crianças, de cartazes informativos para o atendimento em cada instituição (NOVACAP, 1959).

Avaliando uma das instituições do Centro, as professoras de Brasília afirmam:

Referindo-se às Ciências Naturais, é o Jardim Zoológico um grande auxiliar no seu estudo, tanto como motivação, verificação e fixação. Afinal a ordem, a limpeza e a maravilhosa sequência que se processa durante as chamadas lições de coisas muito devem ser ressaltadas bem como o idealismo e esforço da grande educadora- D. Carmem Teixeira, tão bem auxiliada por ótimas professoras que ali trabalham (NOVACAP, 1959, p. 4).

Sobre o Museu de ciências naturais, as professoras fazem menção ao seu acervo de espécimes, bem conservados, ordenados em prateleiras e acondicionados em frascos, vidros, caixinhas ou simplesmente expostos às crianças. Esse setor permitia-lhes trabalharem com os conceitos de ordem, hábitos de limpeza e conservação, dentre outros, além dos conhecimentos curriculares atinentes às ciências. Despertou-lhes particular interesse a Coleção de Ninhos de animais endêmicos da região, embalsamados, e o acervo de arte popular.

Os relatórios referem-se à existência de herbários, terrários, insetários, aquários e formigários, nos quais as crianças observavam vegetais e animais em suas diversas formas de 
desenvolvimento e/ou organização. Informam, ainda, que cada classe possuía um aquário, cuidado pelas crianças, e eram elas que orientavam os visitantes a respeito das técnicas de instalação e conservação utilizadas. Além disso, mencionam o viveiro de animais que havia no Centro Educacional Carneiro Ribeiro, igualmente cuidado pelas crianças, mediante uma escala semanal. Esse viveiro embelezava as classes e proporcionava aos alunos estímulo ao respeito e amor à natureza.

As professoras de Brasília constataram o desejo saudável e espontâneo das crianças em participarem das atividades nos diversos setores e surpreenderam-se com a espontaneidade e responsabilidade que as mesmas assumiam no desempenho das diferentes funções que lhes eram atribuídas. Conforme afirma a professora Helena Lopes de Melo (NOVACAP, 1959),

Esta é realmente uma "Escola da vida para a vida"! Ali a criança aprende brincando. Adquire capacidade de expressar-se oralmente com clareza e facilidade. Dali para a vida terá ela oportunidade de solucionar qualquer situação que (se) lhe apresente. Sendo livre em suas atitudes, enriquece ela, desde cedo - suas experiências para a vida. Age como se fosse um pequeno cidadão integrado numa comunidade (NOVACAP, 1959, p. 5).

Em relação à estrutura física do Centro, a citada professora relata que cada classe possuía mobiliário atraente e adequado à faixa etária das crianças, cuja disposição facilitava trabalho em grupo e outras formas de organização, desfazendo a impressão habitual de rotina e de inatividade. A decoração externa, inteligente e de bom gosto, servia de estímulo a todos, "pois na verdadeira escola não só os mestres ensinam, mas também as paredes, os cantinhos, os móveis, tudo quando bem disposto é motivo para tal.” (NOVACAP, 1959, p.5).

Importante destaque dado pelo Relatório do Estágio de 1958 diz respeito ao currículo desenvolvido naquele Centro, que, diferentemente da estrutura curricular prevalente na escola tradicional, não se centrava em matérias escolares isoladas, mas se organizava por meio de projetos e atividades, envolvendo conteúdos teóricos e práticos, didaticamente tratados de forma integrada. Essa prática pedagógica embasava-se na compreensão de que a criança é um ser ativo, que age com toda a sua personalidade, e não somente uma inteligência pura, naturalmente inclinada a estudos de natureza cognitiva. Assim, caberia ao professor dirigir e escolher as atividades a serem trabalhadas de acordo com os interesses e propósitos do grupo de crianças, tendo em vista o seu desenvolvimento futuro, e, também, o fato de estarem essas atividades relacionadas às experiências infantis oriundas do mundo exterior à escola.

A metodologia utilizada baseava-se nas premissas do ensino globalizado, de modo que os diversos conteúdos se agrupavam em torno de uma ideia central. Assim, as atividades 
educativas possuíam sempre um propósito e ocorriam sob a orientação atenta das professoras. As crianças se expressavam espontânea e livremente em sua atividade criadora, permanecendo concentradas em suas tarefas, razão pela qual a indisciplina não representava um problema. No Relatório (1958) consta observação da professora Santa Alves Soyer de que havia curiosidade do grupo de Brasília em compreender como as professoras do Centro Educacional Carneiro Ribeiro conseguiam despertar o interesse das crianças para as atividades desenvolvidas nas classes, para que esses não se tornassem uma imposição. A explicação para o fato consistia no tratamento didático que adotavam, ou seja, buscavam desde o início estabelecer relação entre o tema do projeto e o interesse dos alunos, valendo-se desse interesse para impulsionar o trabalho espontâneo, de modo que a curiosidade e o interesse das crianças funcionavam como combustível para o desenvolvimento das atividades pedagógicas previstas para cada faixa etária (SOYER, 1958).

Depreende-se, pois, que a curiosidade e o interesse constituem-se elementos importantes no processo de aprendizagem e se manifestam pela atitude exploratória dos alunos. Consoante os pressupostos teóricos de Dewey ${ }^{31}$, o conhecimento resulta de uma atividade originada por meio de uma situação de perplexidade e culmina com a resolução desta situação. Segundo o mencionado filósofo, a perplexidade é uma condição indeterminada e o conhecimento é o elemento de controle, de definição desta condição. Se na vida tudo sucede em situação de perfeito equilíbrio, inexiste a necessidade de querer descobrir ou conhecer, no máximo, há, um re-conhecer automático. Porém, quando este equilíbrio é quebrado por uma situação inesperada, nova, ocorre a necessidade de se investigar as causas da mudança. Entra em cena, então a curiosidade, a observação, a investigação. E a partir dessa situação, é possível saber o que ocorreu. O novo conhecimento é assimilado e volta-se então á situação de equilíbrio.

Nesse sentido, ao comentar sobre o modo como as professoras do Centro utilizavamse de situações que ocorriam em sala-de-aula para desenvolver ou incluir atividades previstas em seus planejamentos, a professora Santa Alves Soyer (1958) relata uma necessidade concreta, exposta na turma, de confeccionar roupas para uma peça teatral a ser apresentada coletivamente. A partir desse 'mote' surgiram várias ações, orientadas e apoiadas pela professora da turma, culminando no arranjo do material produzido no espaço da "lojinha" na sala de aula. Segundo a referida professora, essa situação foi bastante esclarecedora "pelo seu

\footnotetext{
31 Um dos principais filósofos da educação do século XX, John Dewey, formulou princípios que fundamentam a teoria da Escola Nova, que contrapunham-se ao sistema tradicional de educação, e defendia a democracia, o ensino pautado na experiência e no aluno como sujeito do processo de ensino e aprendizagem..
} 
aspecto científico, técnico e pedagógico" (SOYER,1958, p. 3). É ressaltado ainda no citado documento que o trabalho pedagógico, realizado nesses moldes, promove atitude de interação e cooperação. Concebida como elemento integrador e de socialização, importa que a educação seja "o próprio processo de viver, de refazer, reconstruir e melhorar a vida, a escola deve ser encarada como uma comunidade, onde devem prevalecer os mesmos processos sociais que se integram na vida real"' (SOYER, 1958, p. 1).

Os critérios adotados na constituição das turmas consistiam na observância à idade cronológica e sua composição não ultrapassava a 25 alunos por turma, acrescentando, ainda, que as condições materiais das salas de aula atendiam rigorosamente às necessidades pedagógicas, no referente aos aspectos psicopedagógicos e didáticos (SOYER, 1958). No que tange ao relacionamento professor-aluno, registra-se que as professoras do Centro Educacional demonstravam em suas atitudes delicadeza e persuasão no trato com os alunos, atuando sempre como "amigas e conselheiras", conquistando-lhes a confiança; não se ouviam gritos, gestos bruscos, evitando, assim, causar sentimentos de inferioridade ou traumas afetivos.

Pelo exposto, depreende-se que as práticas pedagógicas do Centro Educacional Carneiro Ribeiro estavam em consonância com os princípios defendidos por Anísio Teixeira, no sentido de que a escola não deveria ser vista apenas como espaço de instrução, mas como uma instituição com funções mais amplas a fim de assegurar "oportunidades completas de vida", presentes em situações de trabalho, de vida social e de recreação e jogos (TEIXEIRA, 1962, p. 21-33).

Ao retornarem do estágio, as professoras sentiam-se preparadas para participar do novo tipo de escola preconizado para Brasília. A orientação recebida não tinha em vista a mera reprodução das práticas observadas em Salvador, mas a construção de uma prática docente que, fundamentada nos conhecimentos adquiridos, pudesse concretizar, de forma criativa, os propósitos da educação inovadora na Capital Federal.

\subsection{O Inep e a formação dos quadros técnicos do magistério}

Com a inauguração da nova Capital e a implantação das primeiras escolas propostas por Anísio Teixeira no Plano de Construções Escolares de Brasília (1961), permaneceu crescente a preocupação com a qualificação dos professores, dada a exigência de adoção de novas práticas educativas. As estratégias de aperfeiçoamento para o magistério primário consistiram, num primeiro momento, no oferecimento de cursos, estágios, seminários e 
palestras, que visavam, sobretudo, fortalecer a consciência dos docentes sobre as bases educacionais estabelecidas para os novos modelos de escolas e instrumentalizá-los de modo a promover o seu desenvolvimento profissional e, assim, habilitá-los execução das práticas pedagógicas então requeridas. Merece destaque, ainda, informação do Relatório Quinquenal, (MEC, 1960) em que este afirma que, das ações empreendidas por esse Instituto a mais significativa foi sua participação ativa nos projetos de construções escolares e, principalmente, "no traçado de linhas mestras do sistema educacional que se haveria de instituir no novo Distrito Federal" (MEC, 1960, p. 279, grifo nosso).

Assim, para se compreender a estrutura montada para a qualificação docente na capital brasileira, faz-se necessário retomar a discussão sobre o papel do Inep no campo da formação do magistério naquele momento histórico. O Relatório Quinquenal faz detalhado registro das ações desenvolvidas por essa instituição no âmbito educacional, entre 1955 a 1960, no sentido de incrementar o aperfeiçoamento do ensino escolar primário, a fim de tornar suas ações mais produtivas. Com tal finalidade, tratou de descentralizar suas atividades e instalou cinco Centros Regionais, sendo três criados durante aquele governo, visando à adequação a realidade cultural local. Desse modo, uma das principais estratégias estabelecidas por essa instituição para o aperfeiçoamento de professores configurou-se na criação do Centro Brasileiro de Pesquisas Educacionais - CBPE, em 1955, no Rio de Janeiro e dos Centros Regionais de Pesquisa Educacionais - CRPE, em Porto Alegre, Recife, Salvador, Belo Horizonte e São Paulo.

Conforme já se abordou anteriormente, o Inep, sob a direção de Anísio, tornou-se eixo das ações empreendidas pelo Ministério da Educação e responsável pela formulação das políticas educacionais. Dentro da sua estrutura, o CBPE era o órgão encarregado da elaboração e implementação de estudos e pesquisas, visando conhecer os problemas e necessidades particulares de cada região brasileira, com o propósito de planejar e estabelecer políticas adequadas a cada setor. Importante assinalar que essas pesquisas serviam como dados para organizar as ações voltadas para a qualificação do professorado. Entre as suas funções, cabia ao CBPE oferecer aos professores acesso a metodologias inovadoras de ensino com vistas a aperfeiçoar a prática docente. Os CRPEs eram, por sua vez, responsáveis por materializar essas ações, sendo o seu papel investigar e realizar experiências educacionais nas diferentes localidades, e, simultaneamente, formar especialistas em educação, na maior parte das vezes, ocupantes dos postos de direção ou superiores na hierarquia do sistema (GUIMARÃES, 2008a). 
O Relatório dos trabalhos realizados pela Coordenação dos Cursos do INEP de 1956 a 1960 (INEP, 1960) explicita a ação do programa de aperfeiçoamento do magistério no aludido período. Conforme especificado nesse documento, o referido programa “[...] procurou beneficiar profissionais cuja atuação mais nos parecia favorecer a melhoria do ensino primário brasileiro, por ocuparem postos-chave, nos quais seria máximo o valor reprodutivo do aperfeiçoamento tentado" (p. 1).

Ainda, segundo o mesmo documento, a ações de qualificação voltavam-se para as diferentes categorias de profissionais da educação:

- Administradores dos sistemas escolares, especialistas em educação primária e supervisores de ensino público,

- Supervisores, diretores e professores de escolas normais,

- Diretores e professores de Escolas de Demonstração e Experimentais,

- Supervisores, diretores de oficinas e professores de Artes Industriais para o desenvolvimento do plano de extensão da escolaridade primária,

- Professores especializados, e,

- Professores primários de classe em geral.

O mencionado relatório assim justifica a prioridade dada à formação de quadros técnicos do magistério:

(...) pareceu especialmente adequada para atender aos objetivos em vista, tendo em conta que, impossibilitados de atingir os professores primários do Brasil, em número de 200.000, o plano permitiria, com a colaboração dos Estados, e o aproveitamento do pessoal assim preparado, uma atuação com o máximo de probabilidade de multiplicar-se em seus efeitos, beneficiando um contingente apreciável do professorado (INEP, 1960, p. 1).

Para esclarecer a participação do magistério primário da nova Capital nas ações promovidas pelo Inep para o aperfeiçoamento profissional dos docentes, foram consultados documentos nos arquivos do mencionado Instituto, bem como no acervo da pesquisa sobre a memória da educação do Distrito Federal, da Faculdade de Educação/Universidade de Brasília, especialmente entrevistas de professoras pioneiras da nova Capital. Embora os depoimentos informem sobre a sua inserção nos mencionados cursos ainda no período de construção de Brasília, esta pesquisadora encontrou nos arquivos do Inep documentos que se reportam apenas aos cursos ofertados nos anos de 1963 e 1964 (INEP, 1964). 
Os depoimentos analisados revelam que os cursos ofertados pelo Inep se destinaram, majoritariamente, à formação de especialistas que constituiriam o corpo técnico do magistério da Capital Federal. Consoante a orientação do Instituto, essa qualificação habilitaria o docente a ocupar cargos de chefia - como de diretores, supervisores e orientadores - e, assim, a assumir a responsabilidade pela multiplicação dos conhecimentos adquiridos, tendo em vista atingir o conjunto de professores e escolas. Devido essa configuração, a participação de docentes nesses cursos era condicionada à indicação pela Administração do Ensino, fato que mereceu críticas por docentes não contemplados nessa escolha, deixando transparecer que se tratava de certo protecionismo (CINTRA, 2006; CANEDO, 2001). Cabe salientar, no entanto, o registro de professoras que realizaram cursos de aperfeiçoamento destinados especificamente ao magistério primário e permaneceram atuando em sala de aula.

Os documentos localizados no acervo do Inep, referentes aos cursos ofertados no ano de 1963, contêm dados sobre cada curso, incluindo título, período de realização e nomes dos respectivos cursistas por Estado da Federação, possibilitaram a esta pesquisadora abstrair e organizar as informações sobre a participação dos professores de Brasília nos aludidos $\operatorname{cursos}^{32}$. Nos demais documentos foram encontradas informações dispersas a respeito do objeto da pesquisa, como se passará a expor a seguir.

Uma das primeiras iniciativas do Inep para o aperfeiçoamento docente que contou com a participação de professores primários de Brasília deu-se ainda no período de construção da cidade. Assim, em 1958, por indicação da Administração do Ensino, foram enviadas quatro professoras ao Rio de Janeiro para participarem de um curso de qualificação em educação pré-escolar, que teve a duração de quatro meses. No ano seguinte, mais uma professora participou do referido curso (NOVACAP, 1959). Observe-se que se tratava de uma especialização em área específica, a ser exercida em uma modalidade de instituição que somente viria a funcionar posteriormente, com a implantação do plano educacional de Anísio Teixeira, que previa a construção de um Jardim de Infância em cada quadra residencial da cidade. Como outras ações formativas realizadas antes da inauguração de Brasília, o mencionado curso preparava professores para o modelo de educação preconizado para a Capital da República.

Assim, visando compor os quadros de especialistas que iriam futuramente supervisionar as escolas e as atividades docentes nelas desenvolvidas, foram selecionadas professoras e encaminhadas para os locais onde ocorriam as ações formativas, sob o

\footnotetext{
${ }^{32}$ Vide Quadro 2 - Quantitativo de professores do Distrito Federal nos cursos do INEP (1963/1964) apresentado a p. 83 desta dissertação.
} 
patrocínio do INEP. Observe-se que a participação estava subordinada à área de atuação da docente, como também se buscava preparar professores para o desempenho de funções em áreas a serem posteriormente criadas. As despesas decorrentes da participação nos diferentes cursos eram custeadas por bolsas de estudo concedidas pelo referido Instituto.

É o que relata a professora Maria das Neves Costa Morici (2001) indicada para participar do Curso de Organização e Funcionamento de Bibliotecas Municipais, ministrado pela Escola Nacional de Serviços Urbanos, no Rio de Janeiro. Essa formação destinava-se a preparar profissionais especializados para o trabalho com bibliotecas escolares ${ }^{33}$. Segundo informa a professora Maria das Neves Costa Morici, outras três professoras de Brasília também realizaram o mesmo curso, sob o custeio do Inep.

Depoimentos de professoras destacam a sua participação em cursos e estágios promovidos pelos Centros Regionais de Pesquisa Educacionais - CRPEs. Mencionem-se, entre outros, o Curso de Especialização em Recreação e Jogos, em 1960, no Rio de Janeiro; o Estágio em Jardim de Infância, em 1959, no Rio de Janeiro; o Curso de Especialização em Administração Escolar, em 1962, no Rio Grande do Sul; o Curso de Especialista em Educação, em 1962, em São Paulo; o Curso de Preparação de Professores de Recreação para Escolas Normais e Centros de Aperfeiçoamento de Professores, em 1962, e o Curso de Aperfeiçoamento de Professores de Jardim de Infância, em 1962, ambos no Estado da Guanabara.

Merece referência ainda a formação de especialistas realizada no exterior. Segundo o Relatório dos Trabalhos Realizados pela Coordenação dos Cursos do Inep de 1956 a 1960 (INEP, 1960), essa instituição, com a colaboração do Institute of Inter American Affairs (Ponto IV), desenvolveu um programa de aperfeiçoamento docente em universidades norteamericanas, relativo ao ensino elementar e secundário. Esta formação destinava-se aos professores que atuariam junto aos CRPEs e às Secretarias de Educação estaduais. Os depoimentos de professoras de Brasília (MORRONE, 2012; LÔBO, 2001; TROIS, 1990), afirmam que havia um processo rigoroso para a seleção dos candidatos à mencionada formação em nível superior e que, se aprovados, faziam jus a bolsas de estudo para cobrir as despesas relativas ao seu deslocamento e participação em cursos e estágios realizados em universidades estrangeiras. O mencionado relatório esclarece que, no referido quinquênio, foram ofertados duzentos e quarenta cursos, beneficiando um total de 4.475 professores que receberam bolsa completa.

\footnotetext{
${ }^{33}$ A professora Maria das Neves Morici assumiu, posteriormente, a coordenação da Biblioteca Infantil da Super Quadra 304 Sul, em 1973 (MORICI, 2001).
} 
Contemplada com bolsa de estudo nos Estados Unidos, a professora Ivonilde Morrone realizou, no período de 1961/1962, o Curso de Especialização na Universidade de Indiana (PAIVA; PAIXÃO, 2002). Segundo depoimento da mencionada professora (MORRONE, 2012), esse curso consistia em aulas normais daquela Universidade e treinamento especial para o grupo de brasileiras, que escolhiam as disciplinas extras que desejavam cursar. A professora Ivonilde relata ter escolhido Alfabetização, Supervisão e Administração, especializando-se em didática da linguagem, com abordagem nos universais linguísticos. Essa especialização consistia na aplicação de metodologia americana na alfabetização - Método Global de Encontros ou Método Seriado de Encontro.

No seu ingresso ao magistério público do Distrito Federal, a referida professora já dispunha de formação específica em alfabetização e a sua ida aos E.U.A. objetivou o aprofundamento dos estudos nessa área de conhecimento. Ao retornar ao País, em 1962, a mencionada professora veio a compor o grupo de docentes da Escola Normal de Brasília, dirigindo a Escola de Aplicação de Brasília, até ser convidada pela diretora do Ensino de $1^{\circ} \mathrm{e}$ $2^{\circ}$ graus, professora Ana Bernardes, para a supervisão de ensino na área de comunicação e expressão (MORRONE, 2012).

A professora Olinda Rocha Lôbo (2001), também designada para curso de especialização nos Estados Unidos, relata ter estudado no Texas, em Austin, onde cursou, entre outras disciplinas, a História Constitucional Americana.

Cabe mencionar, ainda, que, a partir de 1961, as políticas de formação do magistério, a cargo do Inep, passam a incluir professoras da nova Capital nos cursos promovidos pelo PABAEE. Contudo, as informações que esta pesquisadora dispõe a respeito da matéria foram extraídas de depoimentos de professoras participantes e documentos encontrados no acervo do INEP relativo aos cursistas de 1963/1964, fontes essas que não possibilitam a reconstituição nominal da totalidade de cursistas de Brasília. Os achados desta pesquisa serão expostos adiante.

Importa mencionar preliminarmente que o PABAEE nasce de acordo bilateral firmado, em 1956, entre o Brasil e os Estados Unidos, representados pelo Ministério da Educação e pela direção da United States Operation Mission to Brazil - USOM-B. Conhecido como Programa Ponto IV, tratava do interesse americano em patrocinar a "transferência de conhecimento técnico para promoção do desenvolvimento econômico de áreas subdesenvolvidas" (PAIVA; PAIXÃO, 2002, p. 58). Segundo argumentam as mencionadas autoras, os EUA e URSS representavam os dois blocos hegemônicos em disputa no cenário mundial, que buscavam adesão dos demais países à sua política expansionista. É nesse cenário 
que se firma esse acordo, visando "[...] colocar à disposição do governo brasileiro serviços de técnicos e especialistas nos setores de atividades relacionados com o desenvolvimento econômico do país e enquadramento nos objetivos de cooperação técnica" (PAIVA; PAIXÃO, 2002, p. 59).

O acordo bilateral compunha-se de três frentes de ação: a Comissão BrasileiroAmericana para o Ensino Industrial - CBAI, o Programa Brasileiro-Americano para o Ensino Secundário - PABAES - e o Programa de Assistência Brasileiro-Americana ao Ensino Elementar - PABAEE. Dentre esses, o PABAEE foi considerado de maior importância em virtude da amplitude do seu duplo objetivo: a modernização do ensino primário por meio do treinamento de professores de escolas normais e a produção de materiais didáticos, visto que dentre os problemas apontados no diagnóstico do sistema educacional brasileiro, esses eram os que apresentavam mais fragilidades. Por outro lado, diagnóstico do USOM-B apontava como principais problemas a serem enfrentados o analfabetismo, a falta de vagas, orçamento insuficiente, formação de professores inadequada, currículo e centralização do sistema de ensino (PAIVA; PAIXÃO, 2002).

O Inep, instituição designada para a execução do Programa ${ }^{34}$, encaminhou o primeiro grupo de professores de Brasília a Belo Horizonte, no segundo semestre de 1961, para participarem de curso do PABAEE destinado à especialização nas metodologias dos conteúdos da escola primária. A duração desses cursos era de um semestre, em período integral, perfazendo um total de $350 \mathrm{~h}$.

A seleção das docentes que participaram do curso foi realizada pela professora Helena Reis, supervisora do sistema educacional do Distrito Federal, ficando cada cursista responsável por uma área específica de conhecimento. No entanto, a formação realizada pelo PABAEE estabelecia que cada professor deveria cursar as diversas metodologias de ensino: Ciências Naturais, Estudos Sociais, Comunicação e Expressão, Supervisão, Jardim de Infância e Ensino Artístico. Entre os cursistas selecionados nesse grupo, constam as professoras Olinda Rocha Lôbo, Dulce Guimarães e Geisa Mendonça (LÔBO, 2001, fita n²).

Em 1962, foram novamente selecionadas docentes de Brasília para os cursos do PABAEE em Belo Horizonte. No entanto, a busca realizada por esta pesquisadora em arquivos do INEP não revelou documentos relativos aos mencionados cursos, sendo as informações obtidas por meio de depoimentos de professoras participantes. Segundo a professora Elzy Lôbo Costa (s/d), sua participação do curso de aperfeiçoamento para

\footnotetext{
${ }^{34}$ Vide Portaria n ${ }^{\circ}$ 7, de 15/01/1957, do Ministério da Educação.
} 
professores do PABAEE ocorreu no segundo semestre de 1962, tendo especializado-se em Metodologia de Ciências.

No que se refere aos cursos realizados para a qualificação docente, nos anos de 1963 e 1964, foram localizadas informações mais detalhadas nos arquivos do INEP. Relatório intitulado "Número de cursistas, em 1963, por Estado e Território" (INEP, 1964), apresenta relação de cursos ministrados no mencionado período, sua duração, Estado da Federação e nomes dos participantes. Esses dados permitiram precisar a participação de professoras brasilienses em diversos cursos promovidos pela instituição, conforme demonstra o quadro a seguir.

Quadro 2 - Quantitativo de professores do Distrito Federal nos cursos do INEP (1963/1964)

\begin{tabular}{|c|c|c|c|}
\hline $\mathbf{N}^{\circ}$ de cursistas & Título do curso & Local & Período \\
\hline 02 & $\begin{array}{l}\text { Curso de } \\
\text { Estudos Sociais } \\
\text { PABAEE }\end{array}$ & $\begin{array}{c}\text { Belo } \\
\text { Horizonte }\end{array}$ & $\begin{array}{l}13 / 2 / 1964 \\
03 / 07 / 1964\end{array}$ \\
\hline 01 & \begin{tabular}{|l|} 
Curso de \\
Pesquisas \\
Educacionais - \\
CRPE
\end{tabular} & $\begin{array}{l}\text { São Paulo } \\
\text { CRPE }\end{array}$ & $18 / 03 / 1963$ \\
\hline 01 & $\begin{array}{l}\text { Curso de } \\
\text { Recursos } \\
\text { Audiovisuais - } \\
\text { CRPE }\end{array}$ & São Paulo & $\begin{array}{l}18 / 03 / 1963 \\
15 / 12 / 1963\end{array}$ \\
\hline 01 & \begin{tabular}{|l|} 
Curso de \\
Professor- \\
Supervisor de \\
Artes \\
Industriais - \\
SENAI \\
\end{tabular} & Rio de Janeiro & $\begin{array}{l}01 / 07 \\
20 / 12 / 1964\end{array}$ \\
\hline 06 & $\begin{array}{l}\text { Curso de } \\
\text { Língua Pátria - } \\
\text { PABAEE }\end{array}$ & $\begin{array}{c}\text { Belo } \\
\text { Horizonte }\end{array}$ & $\begin{array}{ll}1^{\circ} \text { sem. } & 13 / 2 / 1964 \\
\text { a } & 03 / 07 / 1964 \\
2^{\circ} & \text { sem. } 30 / 07 \\
18 / 12 / 1964\end{array}$ \\
\hline 03 & $\begin{array}{l}\text { Curso de } \\
\text { Aritmética - } \\
\text { PABAEE } \\
\end{array}$ & $\begin{array}{c}\text { Belo } \\
\text { Horizonte }\end{array}$ & $\begin{array}{l}30 / 01 / 1963 \\
21 / 06 / 1963\end{array}$ \\
\hline 01 & $\begin{array}{l}\text { Seminário para } \\
\text { Treinamento de } \\
\text { Pessoal em } \\
\text { pesquisas - } \\
\text { CRPE }\end{array}$ & São Paulo & $\begin{array}{l}3 / 1964 \\
07 / 12 / 1964\end{array}$ \\
\hline 04 & $\begin{array}{l}\text { Curso de } \\
\text { Currículo e } \\
\text { Supervisão - }\end{array}$ & $\begin{array}{c}\text { Belo } \\
\text { Horizonte }\end{array}$ & $\begin{array}{l}30 / 01 / 1963 \\
21 / 06 / 1963\end{array}$ \\
\hline
\end{tabular}




\begin{tabular}{|c|l|c|ll|}
\hline $\mathbf{N}^{\circ}$ de cursistas & Título do curso & Local & Período \\
\hline & PABAEE & & \\
\hline 02 & Curso de & São Paulo & $18 / 03 / 1963$ \\
& $\begin{array}{l}\text { especialistas em } \\
\text { Educação - }\end{array}$ & & \\
& CRPE & & \\
\hline 03 & Curso de & Belo & $1^{\text {osem. }}$ & \\
& Ciências & Horizonte & $13 / 02 / 1964$ & a \\
& Naturais - & & $03 / 07 / 1964$ & \\
& PABAEE & & $2^{\circ}$ sem. 30/07 a \\
& & & $18 / 12 / 1964$ & \\
\hline 02 & Curso de & Belo & $1^{\circ}$ sem. & \\
& Educação Pré- & Horizonte & $13 / 02 / 1964$ & a \\
& primária - & & $03 / 07 / 1964$ & \\
& PABAEE & & $2^{\circ}$ \\
& & & sem.30/07/1964 a \\
& & & $18 / 12 / 1964$ \\
\hline
\end{tabular}

Fonte: Elaboração da autora, segundo dados oficiais extraídos do Relatório do Inep (1964)

Conforme se verifica, registra-se a participação de vinte e quatro professoras do Distrito Federal em cursos de temáticas variadas. O Quadro 2 evidencia que quatro deles foram promovidos pelos Inep/CRPEs, em São Paulo, um pelo Senai, no Rio de Janeiro e seis pelo PABAEE, em Belo Horizonte. Tais cursos possuíram carga horária diversificada, variando de alguns dias a mais de um semestre, como é o caso do curso de recursos audiovisuais, promovido pelo CRPE de São Paulo, ocorrido de 18/03/1963 a 15/12/1963.

No Quadro 3, a seguir, consta relação nominal das professoras de Brasília participantes dos cursos realizados em 1963/1964. É possível perceber, observando-se esse quadro, a presença exclusiva de professoras, que demonstra a prevalência do sexo feminino no exercício do magistério primário no aludido período. Note-se que a maioria das cursistas realizou formação de especialista em áreas específicas do currículo da escola primária, as demais participaram de cursos destinados ao exercício de funções para o microssistema de educação.

Quadro 3 - Relação Nominal de Professores do Distrito Federal em Cursos do Inep - 1963/1964

\begin{tabular}{|l|c|c|c|}
\hline \multicolumn{1}{|c|}{ Cursista } & Tipo de evento & Local & Data \\
\hline $\begin{array}{l}\text { Rosa Maria } \\
\text { de Amorim }\end{array}$ & $\begin{array}{c}\text { Curso de Estudos } \\
\text { Sociais- PABAEE }\end{array}$ & Belo Horizonte & $2^{\circ}$ semestre 30/07 a \\
$18 / 12 / 1964$ \\
\hline $\begin{array}{l}\text { Hilda Lutz } \\
\text { Pinheiro }\end{array}$ & $\begin{array}{c}\text { VI Curso de } \\
\text { especialistas em }\end{array}$ & São Paulo & $18 / 03 / 1963$ \\
\hline
\end{tabular}




\begin{tabular}{|c|c|c|c|}
\hline Cursista & Tipo de evento & Local & Data \\
\hline Martins & Educação. & & \\
\hline $\begin{array}{l}\text { Mirêtta de } \\
\text { Mello } \\
\text { Andrade } \\
\end{array}$ & $\begin{array}{l}\text { VI Curso de } \\
\text { especialistas em } \\
\text { Educação. }\end{array}$ & São Paulo & 18/03/1963 \\
\hline $\begin{array}{l}\text { Benedita } \\
\text { Araujo dos } \\
\text { Santos } \\
\end{array}$ & $\begin{array}{l}\text { Curso de Pesquisas } \\
\text { Educacionais- CRPE }\end{array}$ & São Paulo- & $18 / 03 / 1963$ \\
\hline $\begin{array}{l}\text { Maria } \\
\text { Helena de } \\
\text { Lana Tôrres }\end{array}$ & $\begin{array}{c}11^{\circ} \text { Curso de } \\
\text { Recursos } \\
\text { Audiovisuais. - } \\
\text { CRPE } \\
\end{array}$ & São Paulo & $18 / 03 / 1963$ a $15 / 12 / 1963$ \\
\hline $\begin{array}{l}\text { Carmélia } \\
\text { Carneiro da } \\
\text { Silva }\end{array}$ & $\begin{array}{c}\text { Curso de Aritmética } \\
\text { PABAEE }\end{array}$ & Belo Horizonte & $30 / 01 / 1963$ a $21 / 06 / 1963$ \\
\hline $\begin{array}{l}\text { Luzinete } \\
\text { cadete de } \\
\text { Araújo } \\
\text { Lima } \\
\end{array}$ & $\begin{array}{c}\text { Curso de Aritmética } \\
\text { PABAEE }\end{array}$ & Belo Horizonte- & $30 / 01 / 1963$ a $21 / 06 / 1963$ \\
\hline $\begin{array}{l}\text { Darcy } \\
\text { Rodrigues } \\
\text { Mohn }\end{array}$ & $\begin{array}{c}\text { Curso de Aritmética } \\
\text { PABAEE }\end{array}$ & Belo Horizonte & $30 / 01 / 1963$ a $21 / 06 / 1963$ \\
\hline $\begin{array}{l}\text { Elza de } \\
\text { Souza Prado } \\
\text { Costa Lima }\end{array}$ & $\begin{array}{c}\text { Curso de Currículo e } \\
\text { Supervisão - } \\
\text { PABAEE }\end{array}$ & Belo Horizonte & $30 / 01 / 1963$ a $21 / 06 / 1963$ \\
\hline $\begin{array}{l}\text { Nilza } \\
\text { Vaiano }\end{array}$ & $\begin{array}{c}\text { Curso de Currículo e } \\
\text { Supervisão - } \\
\text { PABAEE } \\
\end{array}$ & Belo Horizonte & $30 / 01 / 1963$ a $21 / 06 / 1963$ \\
\hline $\begin{array}{l}\text { Dirce da } \\
\text { Silva }\end{array}$ & $\begin{array}{c}\text { Curso de Currículo e } \\
\text { Supervisão - } \\
\text { PABAEE }\end{array}$ & Belo Horizonte & $30 / 01 / 1963$ a $21 / 06 / 1963$ \\
\hline $\begin{array}{l}\text { Antonieta } \\
\text { Silva }\end{array}$ & $\begin{array}{l}\text { Curso de Língua } \\
\text { Pátria - PABAEE }\end{array}$ & Belo Horizonte & $30 / 01 / 1963$ a $21 / 06 / 1963$ \\
\hline $\begin{array}{l}\text { Irondina } \\
\text { Ribeiro de } \\
\text { Barros }\end{array}$ & $\begin{array}{c}\text { Curso de Ciências } \\
\text { Naturais - PABAEE }\end{array}$ & Belo Horizonte & $\begin{array}{c}1^{\circ} \text { semestre } 13 / 2 / 1964 \mathrm{a} \\
03 / 07 / 1964 \\
2^{\mathrm{o}} \text { semestre } 30 / 07 \mathrm{a} \\
18 / 12 / 1964 \\
\end{array}$ \\
\hline $\begin{array}{l}\text { Maria } \\
\text { Rezende }\end{array}$ & $\begin{array}{l}\text { Curso de Ciências } \\
\text { Naturais - PABAEE }\end{array}$ & Belo Horizonte & $\begin{array}{c}1^{\circ} \text { semestre } 13 / 2 / 1964 \mathrm{a} \\
03 / 07 / 1964 \\
2^{\circ} \text { semestre } 30 / 07 \mathrm{a} \\
18 / 12 / 1964\end{array}$ \\
\hline $\begin{array}{l}\text { Maria } \\
\text { Helena } \\
\text { Apparecida } \\
\text { Paiva de } \\
\text { Moraes } \\
\end{array}$ & $\begin{array}{l}\text { Curso de Ciências } \\
\text { Naturais - PABAEE }\end{array}$ & Belo Horizonte & $\begin{array}{c}1^{\mathrm{o}} \text { semestre } 13 / 2 / 1964 \mathrm{a} \\
03 / 07 / 1964 \\
2^{\mathrm{o}} \text { semestre } 30 / 07 \mathrm{a} \\
18 / 12 / 1964\end{array}$ \\
\hline Cleuza & Curso de Língua & Belo Horizonte & $30 / 01 / 1963$ a $21 / 06 / 1963$ \\
\hline
\end{tabular}




\begin{tabular}{|c|c|c|c|}
\hline Cursista & Tipo de evento & Local & Data \\
\hline $\begin{array}{l}\text { Sant'ana } \\
\text { Cabral }\end{array}$ & Pátria - PABAEE & & \\
\hline $\begin{array}{l}\text { Paula } \\
\text { Frassinetti } \\
\text { Marques } \\
\end{array}$ & $\begin{array}{l}\text { Curso de Língua } \\
\text { Pátria - PABAEE }\end{array}$ & Belo Horizonte & $30 / 01 / 1963$ a $21 / 06 / 1963$ \\
\hline $\begin{array}{l}\text { Myrthô P. } \\
\text { Gonçalves } \\
\text { de Oliveira }\end{array}$ & $\begin{array}{l}\text { Curso de Educação } \\
\text { Pré-primária - } \\
\text { PABAEE }\end{array}$ & Belo Horizonte & $\begin{array}{c}1^{\circ} \text { semestre } 13 / 2 / 1964 \mathrm{a} \\
03 / 07 / 1964 \\
2^{\circ} \text { semestre } 30 / 07 \mathrm{a} \\
18 / 12 / 1964 \\
\end{array}$ \\
\hline $\begin{array}{l}\text { Vera Lúcia } \\
\text { de Melo } \\
\text { Pires }\end{array}$ & $\begin{array}{l}\text { Curso de Educação } \\
\text { Pré-primária - } \\
\text { PABAEE }\end{array}$ & Belo Horizonte & $\begin{array}{c}1^{\circ} \text { semestre } 13 / 2 / 1964 \mathrm{a} \\
03 / 07 / 1964 \\
2^{\circ} \text { semestre } 30 / 07 \mathrm{a} \\
18 / 12 / 1964 \\
\end{array}$ \\
\hline $\begin{array}{l}\text { Oldomira } \\
\text { Godinho }\end{array}$ & $\begin{array}{l}\text { Curso de Estudos } \\
\text { Sociais - PABAEE }\end{array}$ & & $\begin{array}{c}1^{\circ} \text { semestre } 13 / 2 / 1964 \text { a } \\
03 / 07 / 1964 \\
2^{\circ} \text { semestre } 30 / 07 \text { a } \\
18 / 12 / 1964\end{array}$ \\
\hline $\begin{array}{l}\text { Anália } \\
\text { Botelho } \\
\text { Gorayb }\end{array}$ & $\begin{array}{l}\text { Curso de Língua } \\
\text { Pátria - PABAEE }\end{array}$ & Belo Horizonte & $\begin{array}{c}1^{\circ} \text { semestre } 13 / 2 / 1964 \text { a } \\
03 / 07 / 1964 \\
2^{\circ} \text { semestre 30/07 a } \\
18 / 12 / 1964\end{array}$ \\
\hline $\begin{array}{l}\text { Nair Caldas } \\
\text { de Melo }\end{array}$ & $\begin{array}{l}\text { Curso de Língua } \\
\text { Pátria - PABAEE }\end{array}$ & Belo Horizonte & $\begin{array}{c}1^{\circ} \text { semestre } 13 / 2 / 1964 \mathrm{a} \\
03 / 07 / 1964 \\
2^{\mathrm{o}} \text { semestre } 30 / 07 \mathrm{a} \\
18 / 12 / 1964\end{array}$ \\
\hline $\begin{array}{l}\text { Aglair Lino } \\
\text { Bastos }\end{array}$ & $\begin{array}{l}\text { Curso de Professor } \\
\text { Supervisor de Artes } \\
\text { Industriais - SENAI }\end{array}$ & Rio de Janeiro & 01/07 a 20/12/1964 \\
\hline $\begin{array}{l}\text { Celene } \\
\text { Hellowell } \\
\text { Brandão }\end{array}$ & $\begin{array}{c}\text { III }^{\circ} \text { Seminário para } \\
\text { Treinamento de } \\
\text { Pessoal em } \\
\text { pesquisas } \\
\text { educacionais - } \\
\text { CRPE } \\
\end{array}$ & São Paulo & 03/1964 a 07/12/1964 \\
\hline
\end{tabular}

Fonte: Elaboração da autora, com base no Relatório do Inep (1964).

Embora bastante elogiado pelas docentes de Brasília (MORRONE, 2012; LÔBO, 2001; TROIS, 1990), o PABAEE não foi uma iniciativa que conquistou unanimidade mineira, tampouco nacional. A oposição mineira ao Programa surgiu do grupo responsável pela condução dos assuntos atinentes à formação de professores no Estado de Minas Gerais, sob a direção do professor Mario Casasanta, que, juntamente com sua esposa, Lúcia Casasanta compôs o grupo que fundou a Escola de Aperfeiçoamento de Belo Horizonte. Em 1920, parte 
desse grupo, incluindo Lúcia Casasanta, foi enviada para realizar estudos na Universidade de Columbia nos Estados Unidos.

Esse grupo, sob a coordenação da mencionada professora, foi responsável pela introdução do ensino de leitura e escrita pelo método global e pela publicação de material amplamente difundido e utilizado pelas escolas primárias. Assim, a professora Lúcia Casasanta obteve bastante influência na disseminação da referida abordagem metodológica, a qual representava certa unanimidade naquele estado sendo utilizada na qualificação dos supervisores de ensino mineiro até iniciarem-se as atividades do PABAEE.

Segundo as autoras Edil Vasconcelos de Paiva e Léa Pinheiro Paixão (2002), essa rivalidade entre o Instituto de Educação e o PABAEE teve como mote a metodologia de alfabetização, pois o Programa não se utilizava do método global, defendido por Lúcia Casasanta. Outro motivo, talvez mais consistente, que explica a animosidade entre as duas instituições, diz respeito ao papel desempenhado pelo Instituto nas ações do programa de formação do PABAEE.

O Instituto de Educação, até então referência na qualificação de professores de Minas Gerais, ressentiu-se de que as principais decisões nesse âmbito fossem tomadas em outras instâncias, relegando-o mais a um papel de executor.

A esse respeito, as citadas autoras elucidam:

À medida que as diferenças na percepção do papel a ser desempenhado pelas lideranças da casa se explicitam, o PABAEE vai sendo isolado e acaba constituindo uma espécie de gueto. Era uma escola dentro de outra escola, com corpos docentes, classes experimentais anexas, salários e organização do trabalho diferentes (PAIVA; PAIXÂO, 2002 p. 44).

Em suma, as expectativas levantadas pelo Instituto de Educação em relação ao PABAEE, de que este viria para somar-se às ações já desenvolvidas por aquele Instituto, sem causar qualquer alteração no trabalho em andamento, não se cumpriram. Pelo contrário, além de não se integrar às ações do Instituto, o Programa trouxe consigo elementos de competitividade em relação às "legitimidades pedagógicas", uma vez que até então o Instituto de Educação era "o local de produção do conhecimento pedagógico sobre o ensino primário e normal de Minas Gerais" (PAIVA; PAIXÃO, 2002, p. 46). O PABAEE traz consigo, de certo modo, questionamento sobre a legitimidade desse papel representado pelo Instituto.

Cabe ressaltar que as disputas ocorridas entre o Inep e o PABAEE davam-se internamente, uma vez que, como já mencionado, o Programa era uma iniciativa vinculada às ações do Ministério de Educação e àquele Instituto. 
Assim, a oposição ao Programa, em sua manifestação para além do Instituto de Educação mineiro, dava-se tanto no campo pedagógico quanto no campo político-filosófico. Tal divergência pode ser melhor compreendida nas origens do Inep, que, criado pelos signatários do Manifesto dos Pioneiros da Educação Nova, de 1932, difundia as ideias escolanovistas. Assim, nesse contexto, a criação do CBPE e dos Centros Regionais, segundo entendimento de Saviani (2008), caracterizou-se como uma ação de ampliação e aprofundamento das realizações do movimento de renovação educacional de 1932. Essa divergência explicita-se uma vez que o PABAEE possuía orientação tecnicista.

Tal oposição é pontuada pelo citado autor que afirma haver uma distinção básica entre a pedagogia tecnicista e a pedagogia nova. Segundo ele, embora ambas deem importância aos meios, na pedagogia nova a decisão quanto a utilizá-los é partilhada entre professores e alunos, que em comum acordo definem "quando e como farão". Já para a pedagogia tecnicista essa decisão encontra-se centrada, exclusivamente, na figura do professor (SAVIANI, 2008, p. 382).

Segundo relatório citado por Edil Vasconcelos de Paiva e Léa Paixão (2002), o quantitativo de professores de Brasília que participou dos cursos do PABAEE, entre os anos de 1959 a 1964, foi de quarenta e oito, dentre o total de oitocentos e sessenta e quatro professores bolsistas em nível nacional.

O grupo de professoras entrevistadas que participou da formação docente oferecida à época considerou-a como oportunidade ímpar de crescimento profissional. A professora Ivonilde Morrone (2012), que compôs a equipe responsável pelas orientações em Comunicação e Expressão, afirma que o curso do PABAEE representou uma novidade, uma mudança; segundo ela, foi "uma revolução na arte de ensinar" (MORRONE, 2012 p. 8), tendo sido para ela a melhor experiência formativa de que teve oportunidade de participar até aquele momento. A professora Olinda Rocha Lôbo (2001) relata que guarda boas recordações daquela época, esclarecendo que as técnicas que ministravam os cursos eram muito capacitadas. A mencionada professora ressalta que se tratava de uma equipe coesa, bem formada e imbuída de muita responsabilidade para implantar o ensino primário em Brasília.

Assim, embora o PABAEE tenha sido objeto de polêmica quanto a sua orientação filosófico-metodológica, a análise de entrevistas de professoras que atuaram nos primórdios da Capital Federal revela que os cursos oferecidos pelo Programa desempenharam importante papel na qualificação dessas docentes, inserindo práticas inovadoras para a época. Ao encerrar-se a assistência técnica americana, em 1963, o PABAEE passa a integrar o Centro 
Regional de Pesquisas Educacionais de Minas Gerais - CRPE/MG, conforme portaria ${ }^{35}$ do Inep assinada por seu diretor, Anísio Teixeira.

\subsection{A "rede" de formação de professores primários em serviço}

As iniciativas visando o aperfeiçoamento de professores ocorreram antes mesmo da construção da primeira escola na nova Capital com a designação de orientação e supervisão técnica do Inep. A condução dos assuntos relativos à educação esteve, inicialmente, a cargo da NOVACAP que em parceria com o Inep patrocinou a qualificação das primeiras professoras, como exemplifica o envio da equipe da Escola Júlia Kubitschek, para estágio no CRINEP/Bahia.

Com o aumento da demanda e a construção de novas escolas, o trabalho de supervisão às instituições de ensino coube à professora Santa Alves Soyer, primeira diretora da Escola Júlia Kubitschek, sendo que nesta instituição de ensino eram recebidas as docentes das escolas provisórias para orientação pedagógica, em turno contrário à sua regência de classe.

Em 1961, é criada a Fundação Educacional do Distrito Federal, que, a partir de então assumiu a responsabilidade pelo sistema educacional da Capital recém-criada, sendo nomeada a professora Helena Reis para supervisora do Departamento de Ensino Elementar- DEE.

No segundo semestre de 1961, objetivando formar equipe destinada a promover a qualificação docente, esse Departamento destacou um grupo de professoras para participar de cursos de especialização em metodologia educacional no Programa de Assistência Brasileiro Americano ao Ensino Elementar - PABAEE. Esta seleção foi feita pela direção do DEE (LÔBO, 2001, fita $\mathrm{n}^{\circ}$ 2).

Foram, então, selecionadas professoras participantes das duas primeiras turmas de especialistas do PABAEE, que formou, posteriormente, uma equipe técnica de orientadores pedagógicos, composta por três professores para cada área de conhecimento - Comunicação e Expressão, Matemática, Estudos Sociais e Ciências - e também, Jardim de Infância, Supervisão, Orientação Pedagógica e Educacional. A formação dessa equipe destinava-se a qualificação do professorado brasiliense por meio da multiplicação dos conhecimentos adquiridos.

Segundo o documento Coordenação Técnica do - D.E.E. de $1^{\circ}$ Grau do Distrito Federal (DF, 1972, s/n, apud CARVALHO; SOUZA; e BATISTA, 2016), o Departamento de

\footnotetext{
${ }^{35}$ Portaria $\mathrm{n}^{\mathrm{o}} 28$, de 5 de setembro de 1963, Diretoria do INEP.
} 
Ensino Elementar - D.E.E. era o órgão responsável pela assistência pedagógica aos professores, sendo composto por quatro coordenadores pedagógicos, dois auxiliares de coordenação e três orientadores pedagógicos por área, responsáveis por visitar todas as escolas do Distrito Federal. Essa equipe foi posteriormente ampliada, passando a contar com cinco orientadores para cada área, totalizando vinte e cinco componentes. Conforme descrevem as autoras, o referido documento aponta que:

Através de relações horizontais entre membros do grupo: reuniões diárias e
sistemáticas com coordenadores; reuniões semanais com os diretores de
escola; troca de idéias e de ideais, de preconceitos (SIC) e de propósitos
entre si, procurando obter entendimento, buscando uma identificação que
facilitasse os métodos e ações coordenadas, ia a D.E.E. unificando as bases
do ensino do Distrito Federal. (DF, 1972, s/n, apud CARVALHO, SOUZA e
BATISTA, 2016, p. 609).

Assim, a atividade de orientação de professores tinha como alvo a qualificação técnica de cada profissional rumo ao desenvolvimento de sua competência e autonomia profissional, possibilitando-lhes utilizar, com segurança e discernimento, suas próprias estratégias didáticas e não o mero treino ou aquisição de procedimentos mecânicos. Essa diretriz torna-se clara na análise de depoimentos das professoras pioneiras e de documentos relativos ao trabalho de supervisão, os quais apontaram que a orientação mediante o uso de material didático não visava o 'treino' dos professores, mas a aquisição dos conceitos da escola ativa, segundo a qual se aprende com o ato de experienciar. Cabe, então, ao professor ter o traquejo na condução das atividades que possibilitem a atitude de experimentação pelos alunos.

Além da função de orientação pedagógica aos demais professores, as equipes de primeiros orientadores também foram encarregadas da elaboração dos currículos das disciplinas sob sua responsabilidade. Tal informação foi obtida pelos relatos da professora Olinda Rocha Lôbo (LÔBO, 2001), componente do grupo responsável pela orientação de matemática, e da professora Ivonilde Morrone (MORRONE, 2012), componente da equipe de Comunicação e Expressão. Acredita-se que a mesma estratégia tenha ocorrido para as demais áreas disciplinares. Contudo, não foram encontrados registros ou depoimentos de professores das outras áreas que pudessem confirmar essa hipótese.

A elaboração do primeiro currículo de Matemática do Distrito Federal esteve a cargo das professoras Olinda Rocha Lôbo, Geiza de Freitas e Dulce Guimarães. Segundo depoimento da primeira: "Era um trabalho inédito na época, tanto do ponto de vista da graduação do conteúdo, graduação de dificuldades, adequação de interesses da faixa etária, 
continuidade de conteúdo que desse base para os outros cursos, um trabalho muito bom" (LÔBO, fita 1-A, p. 30).

Essas três orientadoras iam para as escolas e agrupavam os professores, que, então, realizavam o planejamento, avaliavam, e, a partir desse trabalho de avaliação, o currículo foi se organizando, de certo modo já definitivo, uma vez que o mesmo era experimentado e avaliado junto ao grupo de professores por três vezes seguidas, só passando a ser definitivo após a terceira vez. (LÔBO, 2001).

Tendo sido a primeira orientadora de ensino na área da alfabetização, em Brasília, a professora Ivonilde de Faria Morrone é proveniente de Anápolis, Goiás, onde, após concluir o magistério participou de curso de especialização em alfabetização promovido pelo INEP, no Rio de Janeiro, e, em seguida participou do curso do PABAEE, em Belo Horizonte. Ocupou nessa cidade goiana, o cargo de supervisora de ensino na área de alfabetização e participou das "Jornadas Pedagógicas pelo Estado de Goiás", responsável pelo treinamento de professores no interior do Estado.

A professora Ivonilde veio para Brasília após aprovação no concurso nacional, ocorrido em 1960. Iniciou sua docência trabalhando por alguns meses na Escola Júlia Kubitscheck, assumindo, em seguida, a vice-direção da Escola Classe 308 Sul e posteriormente, o cargo de direção. Essa escola destacou-se pelo seu trabalho diferenciado. Situada na primeira Super Quadra de Brasília, foi inaugurada juntamente com a nova Capital, em 1960. Segundo depoimento de professoras que atuaram na mencionada escola, o planejamento coletivo resultava do envolvimento de todo o corpo docente e a comunidade escolar era bastante participativa. Tendo em vista que a cidade ainda estava em processo de construção, essa instituição de ensino e a Escola Parque dessa mesma Entrequadra cumpriam o papel de espaços de lazer e de convivência social, de modo que havia um forte espírito de equipe, e assim o trabalho era desenvolvido com bastante facilidade (LÔBO, 2001), (MORRONE, 2012).

Os depoimentos da professora Ivonilde Morrone (2012) como também de outras professoras que atuaram nessa escola mencionam que, na referida escola desenvolveu-se uma das primeiras experiências de participação democrática das crianças, qual seja, a de promover a eleição para Presidente da República entre seus alunos motivada pelo fato de estarem vivendo um momento histórico de construção da nova Capital do país e em virtude da proximidade com o poder.

Depoimentos de professoras pioneiras acerca das práticas desenvolvidas nas novas escolas no Plano Piloto apontam para a influência exercida pela pedagogia inovadora que 
estava sendo implantada em Brasília, como também retratam a admiração devido ao desenho arquitetônico $^{36}$ de suas escolas, intencionalmente voltadas para promoção de atividades socializantes, democráticas e de relações horizontalizadas, como exemplificado no relato da professora Olinda em entrevista ao jornal Correio Braziliense: “A Escola Classe era o reflexo de tudo aquilo. Uma escola que nem parecia uma escola, sem janelas altas, sem aquele silêncio absoluto. Não havia cerca nem muro. Era tudo muito livre, o cerrado se misturava à escola" (LÔBO, 2010, s/n).

Esse relato relaciona-se ao Plano de Construções Escolares de Brasília, no qual Anísio Teixeira delineia uma planificação ampla que prescreve uma filosofia de educação para a nova Capital, baseada em relações democráticas e igualitárias. De acordo com Frago e Escolano, “O espaço educativo (reflete) as inovações pedagógicas, tanto em suas concepções gerais como nos aspectos mais técnicos", (FRAGO e ESCOLANO, apud PEREIRA E ROCHA. 2011, p. 166). Assim o projeto arquitetônico das escolas era formulado de modo a favorecer novas práticas educativas e novas formas de convívio social.

Compondo também o grupo inicial de coordenadores, a professora Elzy Lobo Costa, proveniente da cidade de Formosa, Goiás, veio para Brasília em 1961 e iniciou sua carreira na nova capital como professora, e, posteriormente foi vice-diretora na escola classe 308 Sul. A mencionada professora participou do curso de aperfeiçoamento para professores do PABAEE, no segundo semestre de 1962 e do curso de Orientação Educacional, no ano seguinte. Ao retornar a Brasília, em 1962, veio a compor a primeira equipe técnica de orientadores pedagógicos, atuando como orientadora de metodologia de Ciências, a partir do início de 1963 até o ano de 1968.

Ao ser entrevistada, em 2015, a professora Elzy Lobo Costa apresentou caderno de anotações pessoais em que consta o registro das reuniões semanais que ocorriam para orientação do grupo de especialistas do qual fazia parte. Essas anotações, juntamente com os depoimentos de outras professoras pioneiras, permitem uma visão mais detalhada do trabalho cotidiano desse grupo na ação formativa desempenhada junto às escolas do Distrito Federal.

Há de se considerar, como apontado por Le Goff, (1986), que esta pesquisadora teve o cuidado de não analisar o documento fora de seu contexto, mas observá-lo no conjunto de monumentos em que se insere. Segundo o citado autor, esse novo documento, ampliado e

\footnotetext{
${ }^{36}$ Anísio Teixeira, ao explicitar a arquitetura das escolas a serem construídas em Brasília, dizia que "Já não se tratava de escolas e salas de aula, mas de todo um conjunto de locais, em que as crianças se distribuem entregues às atividades de "estudo", de "trabalho", de "recreação", de "reunião", de "administração", de "decisão" e de vida e convívio no mais amplo sentido desse termo" (TEIXEIRA, 1962, p.7).
} 
transformado em dado, deve ser analisado e questionado. A análise crítica de fontes diversas sobre um determinado conhecimento pode elevá-lo "do campo da memória para o campo da ciência histórica" (LE GOFF, 1986, p. 538).

Assim o cruzamento de informações sobre o trabalho de qualificação docente no período analisado revelou que havia a preocupação institucional em promover-se o preparo adequado do professor regente no próprio local de sua atuação profissional, de forma que o trabalho de orientação não fosse considerado como um receituário. Buscava-se, por meio de estudos e da orientação direta da equipe para esse fim designada, constituir a competência docente. As diretrizes para a equipe de orientação alertavam sobre a finalidade de seu trabalho, apontando para o 'perigo' da artificialidade das “aulas-modelo", desenvolvidas em um ambiente controlado e visando fornecer um receituário inócuo para a prática do professor, uma vez que as situações cotidianas de sala de aula são únicas, não se repetem.

Essa preocupação explica-se em virtude de que uma das estratégias de formação constantes, do período em questão, era a observação das aulas nas escolas de aplicação. Havia o cuidado de a que a sua utilização não gerasse a ideia de aulas de demonstração como fórmula ou modelo para reprodução.

Tal crítica surgiu, anos mais tarde, com o questionamento de que este era um trabalho bastante direcionador que tolhia a liberdade criadora dos professores. Dentre os depoimentos analisados, há uma observação da professora Ivonilde Morrone, em entrevista datada de 2012, em que a mencionada docente, refletindo sobre a orientação dada ao trabalho de alfabetização à época, diz que "as professoras eram muito conduzidas" e que "a criatividade das professoras existia, mas o fio condutor era amarrado". Em seguida a essa crítica, a mencionada professora pondera que havia um grande número de professores. Do que se depreende que a ampliação do sistema educacional, provavelmente, tenha gerado a disparidade entre o número de técnicos educacionais e de professores, fator que pode ter dificultado a oferta de curso que possibilitasse a constituição de base teórica que possibilitasse a ação docente criativa.

A distinção entre escola-receituário e escola promotora de conhecimento é feita pelo educador Lourenço Filho (2001), quando este esclarece a diferença entre escola-modelo e escola de demonstração: “... "escola - modelo" - escola de esquemas feitos e intangíveis [...] "escola de demonstração", escola de alto nível técnico, com caráter experimental" (LOURENÇO FILHO, 2001, p. 57).

Nesse sentido, conforme disposto no caderno de anotações da professora Elzy Lobo Costa, a professora Helena Reis orientava que o professor deveria estar preparado para estabelecer, em sua prática cotidiana, as adequações necessárias às características específicas 
de seu alunado e às situações inesperadas (COSTA, 1963). Essa condição docente torna-se possível por meio de sua qualificação pessoal. Em seu depoimento a professora Santa Alves Soyer tece elogios à orientação pedagógica sob a direção de sua sucessora na função: "D. Helena procurava promover o trabalho do professor, o trabalho do professor era muito bem orientado." (SOYER, 1990, p. 33).

A análise dos depoimentos e das anotações evidencia que, na busca por essa qualidade técnica, os orientadores eram admoestados de que sua função era orientar quanto às técnicas de trabalho, sendo-lhes recomendando, ainda, que fosse indicada a bibliografia utilizada nos cursos do PABAEE para o estudo dos professores. Segundo a professora Helena Reis "a característica autêntica da supervisão é fazer o indivíduo criar" (COSTA, 1963). Para isto, as atividades de orientação do professorado brasiliense, sob a orientação do grupo acima referido, compunham-se, além da formação técnico-pedagógica, pela confecção e demonstração do uso de material didático apropriado para a temática estudada. Conforme relata a professora Olinda Rocha Lôbo

[...] quando ia para as orientações no Gama, em Sobradinho, Planaltina, Brazlândia, Taguatinga, nós íamos numa Kombi. Então, tinha aquela "braçada" de materiais e as professoras ficavam tão entusiasmadas com o material, elas brincavam demais: "Lá vem a dona matemática, carregada de material”. E todas queriam fazer, tinham muito gosto. (LÔBO, 2001, fita $\left.\mathrm{n}^{\mathrm{o}} 2\right)$.

Assim, a orientação para as demais disciplinas era a de se confeccionar material didático para suporte do trabalho pedagógico. Em seu depoimento, a professora Ivonilde Morrone, orientadora da área de Comunicação e Expressão, afirma que, pela primeira vez, o material concreto era utilizado pelas crianças desde o início do processo de alfabetização (MORRONE, 2012).

$\mathrm{Na}$ base da formação realizada no PABAEE para a qualificação dos professores, estava a psicologia do desenvolvimento infantil, a partir da qual se trabalhava a questão metodológica e os conteúdos de ensino. Os fundamentos do desenvolvimento da criança apoiavam-se na teoria de Jean Piaget (RAPPAPORT, et. al. 1981), que explica a gênese do conhecimento humano, ou seja, quais são os processos mentais utilizados para resolução de problemas e quais processos possibilitam as ações nesse sentido. Por meio da psicologia genética, o mencionado autor explica o desenvolvimento do conhecimento, defendendo a existência e evolução de estruturas mentais, desde o nascimento até o alcance do pensamento lógico formal, na adolescência. Buscava-se compreender os processos mentais utilizados pela 
criança para a solução de conflitos. A partir de intensa pesquisa, Piaget (RAPPAPORT, et. al. 1981) concluiu que existem estruturas mentais peculiares a cada faixa etária do ser humano e que essas estruturas funcionam de modo característico em cada etapa de desenvolvimento do indivíduo.

A contribuição desta teoria para a educação é que, a partir do conhecimento das características de cada fase, e, de como ocorre a compreensão da criança naquele determinado nível, é possível a melhor adequação do trabalho pedagógico às necessidades e interesses inerentes a cada faixa etária. Assim, cada fase do desenvolvimento mental relaciona-se a determinadas características que são inerentes àquela etapa. Segundo o pensador suíço, no processo de desenvolvimento evidencia-se a existência de estágios, que ocorrem sempre nessa determinada ordem: sensório-motor, pré-operacional, operacional concreto e período das operações formais.

Os estudos de Jean Piaget demonstraram que apenas após o final do período das operações concretas, já no início da adolescência, o indivíduo estará apto a pensar abstratamente, ou seja, independente de objetos concretos.

Dessa forma, os cursos ofertados pelo PABAEE consideravam de singular importância o uso de material didático em todas as áreas curriculares. Nesse sentido, eram ministradas aulas de confecção de material didático como apoio às atividades pedagógicas e didáticas específicas a cada área de conhecimento Segundo relata a professora Olinda, foi feita uma campanha, buscando convencer os docentes de que o ensino da Matemática deveria ser feito sempre baseado na compreensão, a qual constata a docente pioneira, foi exitosa em virtude da utilização desse material didático (LÔBO, 2001).

A formação em Belo Horizonte trouxe mudanças na metodologia utilizada no ensino da aritmética, o qual se baseou no método compreensivo, que por meio do uso de material concreto buscava adequar-se ao estágio de desenvolvimento mental em que se encontravam as crianças.

Para o ensino da Matemática, orientava-se que fosse feito sempre com a utilização de material didático, por se tratar de disciplina abstrata, requerendo inicialmente a apresentação de material concreto para a formulação da ideia matemática. Assim esse material tornava o ensino mais interessante e atraente, possibilitando a fácil compreensão da criança, como também auxiliava na fixação dos conhecimentos adquiridos. Segundo relata a professora Olinda, foi feita uma campanha, buscando convencer os docentes de que o ensino da Matemática deveria ser feito sempre baseado na compreensão, a qual constata a docente pioneira, foi exitosa em virtude da utilização desse material didático (LÔBO, 2001). 
O conceito de utilização de material concreto também pautava o trabalho de comunicação e expressão. Conforme relata a professora Ivonilde Morrone (2012), esse consistia na composição e decomposição de palavras por meio do uso de fichas móveis, estratégia metodológica do método global. Havia, então, orientação para generalização do uso de fichário. A mencionada professora detalha:

[...] e as crianças, pela primeira vez, usavam um material concreto desde o início. Eles também recebiam a frase, eles cortavam a frase, e aí, recebiam a ficha da palavra, depois recebiam a ficha contendo as sílabas, depois eles montavam o nome do Ataliba com as fichinhas, na frente da palavra [...] e depois os fonemas eram apresentados no fichário (MORRONE, 2012, p.15).

A partir desse trabalho, havia a produção de pequenos textos em que as crianças ditavam os trechos elaborados mentalmente e a professora assumia o papel de escriba. Apesar de ainda não poderem imprimir seus pensamentos de forma escrita, essa atividade favorecia o desenvolvimento da oralidade. Após o seu registro a professora lia o texto, sendo que então, cada criança se reconhecia como autora do texto. Essa produção coletiva era bastante explorada, e, segundo a professora Ivonilde Morrone, as crianças diziam "eu contribui com essa frase, eu disse isso, eu disse aquilo" (MORRONE, 2012, p. 5). Por meio dessa atividade, ia-se trabalhando o reconhecimento de palavras, a construção de palavras com fichas, e, na sequência, as crianças iniciavam o registro de pequenos textos.

Exemplificando a operacionalização desta metodologia, a professora supracitada relata sobre trabalho realizado na Escola de Aplicação da Escola Normal de Brasília. Esta se situava em região onde havia um matagal. Segundo suas palavras: "aquele matagal, sabe, aquela pobreza rica, aquela coisa encantadora”, então a professora sentava-se ao fundo da sala e cada criança escolhia onde queria se sentar, e, então, compunham seus textos. A professora Ivonilde conclui: "Nossa, era lindo [...] então eles faziam coisas lindas sobre o céu, sobre o matagal" (MORRONE, 2012, p. 22).

Os cursos do PABAEE proporcionaram uma mudança no comportamento pedagógico em sala de aula e a democratização das relações entre professor e alunos. Assim, a partir das orientações recebidas por meio do Programa em Belo Horizonte, adotaram-se novas atitudes como a de organização diferenciada das carteiras em sala de aula, em que a criança já não ficava 'olhando para a nuca do colega', impossibilitada de comunicar-se. Nesse mesmo sentido, iniciou-se a adoção de relações mais horizontalizadas: as crianças começaram a sentar-se no chão, ao redor da professora, para rodas de conversas. Foi "uma revolução na arte 
de ensinar" com o estabelecimento da comunicação oral, em sala de aula, que anteriormente não existia (MORRONE, 2012, p. 8).

O aprendizado da confecção de material didático como apoio às atividades pedagógicas bem como as didáticas específicas a cada área de conhecimento constituía-se em disciplinas importantes do PABAEE, uma vez que os cursos ofertados por esse Programa caracterizavam-se por ênfase no conhecimento sobre a psicologia do desenvolvimento infantil, e considerava, ainda, de singular importância o uso de material didático em todas as áreas curriculares, coerentemente com sua filosofia de valorização do método e "do pressuposto de que os problemas do ensino primário poderiam ser combatidos com boas metodologias" (PAIVA; PAIXÃO, 2002, p. 55).

Nesse contexto, o trabalho de qualificação de professores, no Distrito Federal, supunha estudo teórico e confecção de material didático-pedagógico para que as aulas fossem interessantes, atrativas e atendessem o nível de maturidade intelectual de seus alunos. Assim, a atividade de formação de professores em Matemática baseava-se no método da redescoberta dirigida, que consistia na utilização do método científico adaptado pedagogicamente às estruturas mentais da criança, no qual o conhecimento é apresentado gradativamente, com materiais concretos e em situações-problema que possibilitam a criança, ao manuseá-los, estabelecer relações e ir construindo, paulatinamente, os conceitos, por meio de suas próprias descobertas. Orientava-se que as aulas ocorressem sempre com a utilização de material didático por se tratar de disciplina abstrata, requerendo, inicialmente, a apresentação de material concreto para a formulação da ideia matemática. Assim esse material tornava o ensino mais interessante e atraente, possibilitando a fácil compreensão da criança, como também para o auxílio na fixação dos conhecimentos adquiridos.

Registre-se o depoimento entusiasmado da professora Olinda Rocha Lôbo sobre a metodologia utilizada para a orientação matemática: “[...] e é interessantíssimo o ensino da Matemática desse jeito, porque a criança descobre e depois caminha sozinha na Matemática, vai descobrindo as relações..." (LÔBO, 2001, fita 2). Segundo as orientações adquiridas na formação do PABAEE, o professor deveria

[...] fazer o trabalho com a criança no sentido de que ela observasse bastante, comparasse, estabelecesse relações e concluísse, esse é o caminho do método científico, só que é o caminho do método científico menos complicado do que o método científico do científico, ele é mais método pedagógico, então, com isso... espetacular você sentir que vai formando na criança habilidades, atitudes e comportamentos do método científico, ela fica crítica, fica com raciocínio científico, não mais acredita em qualquer coisa 
que falem para ela, ela vai... no próprio pensamento dela, que ela já está acostumada, já trabalhou, ela vai descobrindo habilidades de observar muito, porque se observar pouco, ela não tem conclusão boa, ela vai desenvolvendo habilidade... porque ela tem que comparar depois que observa, e, quando compara, ela sabe a diferença entre uma coisa e outra, e sabe que a conclusão é mais rica conforme a maior parte de comparações e de observações que fizer. E, melhor ainda, se esse trabalho começa no Jardim de Infância, é o desenvolvimento da criança; a criança, quando trabalhada, você desenvolvendo a percepção dela... as percepções são a base da inteligência, quanto melhores percepções uma pessoa tem, melhor inteligência, melhor qualidade de inteligência ela tem [...] (LÔBO, Entrevista, fita $\mathrm{n}^{\circ} 2$ ).

Conclui-se, a partir dos depoimentos relacionados anteriormente, que houve trabalho de orientação rotineira e constante, demonstrando que se organizou uma estrutura para o aperfeiçoamento de professores, que foi se alterando de acordo com o crescimento do professorado brasiliense. Nota-se também que a participação do Inep na condução dessa ação, no período investigado, foi constante, seja por meio dos Centros Regionais de PesquisaCRPE, seja pelo Programa de Assistência Brasileiro-Americana ao Ensino ElementarPABAEE. Conforme já explicitado, os dados analisados permitiram a reconstituição do trabalho desenvolvido para o aperfeiçoamento de professores nas áreas de comunicação e expressão e de matemática, não tendo sido encontrado material que possibilitasse a análise nas demais áreas do conhecimento. Acredita-se, todavia, que a orientação didático-pedagógica tenha seguido na mesma linha filosófica utilizada para a condução dos trabalhos de comunicação e expressão e de matemática. 


\section{CONSIDERAÇÕES FINAIS}

A implementação do plano educacional de Brasília demonstrou o esforço conjugado de diversas instâncias a fim de concretizar a educação idealizada por Anísio Teixeira para a nova Capital. A proposta educacional pode ser considerada inovadora em virtude de vários aspectos que a distinguem da educação praticada à época, como a mudança nas relações de ensino e de aprendizagem, ancoradas nos pressupostos da escola nova e caracterizadas, assim, como mais dinâmicas, democráticas e participativas. A organização curricular também apresentou uma perspectiva diferenciada, sendo composta além das disciplinas tradicionais, por atividades complementares de trabalho e de caráter social.

A pesquisa realizada possibilitou, ainda, constatar a introdução de metodologias inovadoras para o contexto da época, revelando práticas de natureza democrática, caracterizadas pela mudança de centralidade do processo educativo, anteriormente focado no ensino e na figura do professor, passa a focar-se, então, na aprendizagem e no aluno.

Foi evidenciado que os requisitos demandados para o ingresso de professores na escola elementar no sistema público de ensino do Distrito Federal em seus primórdios basearam-se em critérios de elevada exigência, que resultou na constituição de um corpo docente especializado e apto a implementar o plano educacional estabelecido para Brasília em seus primórdios.

Cabe ressaltar o papel desempenhado pela Escola Júlia Kubitscheck, considerada o embrião do modelo da educação inovadora da nova Capital Federal, que exerceu a função de polo de formação de professores e de irradiação do projeto pedagógico caracterizado pelo sistema inovador de educação integral composto por escolas classe e escolas parque.

Nesse sentido, empreendeu-se investimento considerável na formação de professores, como analisado ao longo desta dissertação, para a qual a participação do Instituto Nacional de Estudos e Pesquisas Educacionais Anísio Teixeira- Inep foi preponderante, visando dotá-los de uma competência capaz de realizar a educação de vanguarda que se aspirava possuir a moderna Capital. Esse investimento consistiu na concessão de bolsas de estudo e viagens para que os docentes participassem de atividades de formação em outros estados da nação, e nos E.U.A. Também ocorreram atividades de formação desenvolvidas in loco, com profissionais locais e técnicos convidados para ministrar a qualificação de corpo técnico, composto por docentes especializados de Brasília. Evidenciou-se que tais ações foram intensas nos primeiros anos na capital. 
Buscou-se, a partir dessa ação formativa, organizar uma rede para multiplicação de conhecimentos, de modo a contemplar os docentes de todos os estabelecimentos de ensino. Esta rede, que teve início a partir das atividades de qualificação docente na Escola Júlia Kubistchek, foi caracterizada em formatos diferenciados, acompanhando a expansão do quadro de professores da nova Capital, conforme explicitado nesta dissertação.

Por outro lado, o presente estudo mostra que as ideias de Anísio Teixeira, praticadas nos primórdios da nova Capital Federal, são ainda atuais e pertinentes, uma vez que, apesar dos avanços em relação à democratização da educação brasileira ocorridos nas duas últimas décadas, os propósitos por ele defendidos permanecem, ainda, como meta a se buscar. Essa busca evidencia não se ter alcançado, até hoje, os objetivos visados pela renovação educacional no Brasil. Especialmente os que se reportam à qualidade na educação, em cujo âmago se destaca a ação docente.

A preocupação atual com a formação docente presente na legislação educacional brasileira, especificamente na Lei de Diretrizes e Bases de 1986, em seu parágrafo $1^{\circ}$, artigo 62, que trata da formação inicial e continuada de professores, a ser promovida pelos sistemas de ensino, torna clara a importância da qualificação de professores. Esta tem estado presente em discussões acadêmicas, sindicais e das associações representativas desse campo profissional.

Mais recentemente, o Plano Nacional de Educação - Lei no 13.005, de 25 de junho de 2014 -, (BRASIL, 2014) evidenciou a formação docente como um tema prioritário da atualidade e se pôde constatar que suas propostas são semelhantes a muitas das formuladas pelo educador Anísio Teixeira, em relação ao estabelecimento de políticas públicas e de ações voltadas para a transformação da educação brasileira.

É interessante registrar que, tendo se passado cinquenta e seis anos da inauguração de Brasília, onde o sistema de escola integral foi implantado, a partir da inovação em tempos, espaços, relações e aprendizagens, essas ideias renasçam consubstanciadas em uma proposta de melhoria na qualidade da educação do país, e a valorização de professores, outra causa defendida por Anísio Teixeira, seja retomada como elemento da atualidade. A valorização da profissão docente coloca-se, de forma pulsante, na questão relativa à formação em exercício de professores, no PNE (BRASIL, 2014), que estabelece a valorização dos profissionais da educação e trata dessa temática de forma específica, demonstrando que ainda se faz necessário ampliar a discussão em torno desse tema nos dias atuais. Nesse sentido, conhecer a experiência realizada nos primórdios de Brasília pode contribuir para o debate em torno da educação que se almeja para a cidade e para a nação. Cabe, ainda, ressaltar o que aponta Bosi 
(2003) a respeito da utilização da história oral enquanto metodologia de pesquisa, que "a memória opera com grande liberdade escolhendo acontecimentos no espaço e no tempo, não arbitrariamente, mas porque se relacionam através de índices comuns. São configurações mais intensas quando sobre elas incide o brilho de um significado coletivo." (BOSI, 2003, p. 31). Nesse sentido, observou-se que a experiência pioneira na implantação do sistema educacional de Brasília imprimiu fortes marcas em seus protagonistas, de modo que, em seus relatos, foi possível apreender o significado coletivo da participação de cada professora nesse trabalho inovador.

Por fim, gostaria de utilizar de licença poética, nesta dissertação acadêmica, para oferecer uma homenagem aos professores pioneiros de Brasília, em gratidão ao seu legado para nós, docentes atuais da rede pública de ensino do Distrito Federal, por meio do seguinte poema:

Quem vai na frente Não vê caminho Cai no buraco Pisa no espinho Pés machucados Olhar dolente Mãos calejadas Quem vai na frente

Quem vai na frente Não vê estrada Em plena mata Abre picada Levanta a terra Joga a semente Não colhe flores

Quem vai na frente

Quem vai na frente Não tem asfalto Não tem conforto Só sobressalto Planta e não colhe Luta e não vence Sofre e não cata Quem vai na frente

Mas abre estradas Planta caminhos Buracos tapa Arranca espinhos 
E deixa as flores

Que sempre faz

Feliz e alegre

Quem vem atrás.

Luis Osvaldo Santiago Moreira de Souza (s/d.) 


\section{REFERÊNCIAS}

AMARAL, Clara Ramthun. A formação do magistério primário nos primórdios de Brasília (1960-1964): Memórias de uma utopia possível. 112 p. Dissertação (Mestrado) Programa de Pós-Graduação em Educação, Faculdade de Educação, Universidade de Brasília. Brasília, 2014.

AZEVEDO, Fernando de. Manifesto dos Pioneiros da Educação Nova (1932) e dos educadores (1959). Fundação Joaquim Nabuco. Recife: Editora Massangana, 2010.

BERTRAN, Paulo. História da terra e do homem no Planalto Central: Eco-história do Distrito Federal: do indígena ao colonizador. Brasília: Solo, 1994.

BRASIL. Plano Nacional de Educação (PNE). Brasília: Câmara dos Deputados, Edições Câmara, 2014.

BREGLIA, V. L. A.; LIMA Cecília Neves. A formação dos professores: novos deveres, novos zelos, novas condições, novos métodos. In: MENDONÇA, Ana Waleska P.C.; XAVIER, Libânia N. (org.). Por uma política de formação do magistério nacional: 0 INEP/MEC dos anos 1950/1960. Brasília: Instituto Nacional de Estudos e Pesquisas Educacionais Anísio Teixeira (INEP), 2008.

BLOCH, Marc. Introdução à história. Tradução de Maria Manuel, Rui Grácio e Vítor Romaneiro. ed. (crítica). Publicações Europa-América: Portugal, 1997.

BOSI, Ecléa. O tempo vivo da memória: ensaios de psicologia social. São Paulo: Ateliê Editorial, 2003.

CARVALHO, Rosália Policarpo Fagundes; SOUZA, Mônica Menezes de; BATISTA, Oliveira Carmyra. A circulação de revistas pedagógicas no decênio de 1960 no ensino primário de Brasília-DF. In XII Seminário Temático Saberes Elementares Matemáticos do Ensino Primário (1890- 1970): o que dizem as revistas pedagógicas? (1890-1970), PUCPR, Paraná, 8 a 11 de abril de 2015.

CHIZZOTTI, Antônio. Pesquisa qualitativa em ciências humanas e sociais. 2. ed. Vozes, Petrópolis, RJ: 2008.

CORDEIRO Célia Maria Ferreira. Anísio Teixeira, uma "visão" de futuro. Estudos Avançados. On line version ISSN 1806-9592. http://dx.doi.org/10.1590/SO103401420001000200012. Acesso em 22 de março de 2016.

DELGADO, Lucília de Almeida Neves. História oral: memória, tempo e identidades. 2. ed. Belo Horizonte: Autêntica, 2010. 
DISTRITO FEDERAL. (BRASIL). Secretaria de Estado de Educação. 40 anos de educação em Brasília. Brasília: Subsecretaria de Planejamento e de Inspeção de Ensino. 2001.

DISTRITO FEDERAL. (BRASIL). Departamento de Planejamento Educacional. A origem do Sistema Educacional de Brasília: Criação da CASEB, 22/12/1959. Brasília, 1984.

GIL, Antônio Carlos. Métodos e técnicas de pesquisa social. 6. ed. São Paulo: Atlas, 2008.

GUIMARÃES, Luiza Angélica Paschoeto. Anísio Teixeira: atuação educacional e propostas para a formação do magistério primário. 2008. 117 p. Dissertação (Mestrado em Educação) Faculdade de Educação. Universidade Católica de Petrópolis, Petrópolis, 2008a.

Políticas de Aperfeiçoamento para o Magistério: atuação de Anísio Teixeira no INEP (1952-1964). In: V Congresso Brasileiro de História da Educação: O ensino e a pesquisa em História da Educação. São Cristóvão/Aracaju: Universidade Federal de Sergipe/Universidade Tiradentes, 2008b.

LE GOFF, Jacques [et al.]. Tradução Carlos da Veiga Ferreira. História e nova história. Lisboa: Teorema, 1986.

LE GOFF, Jacques. Trad. Bernardo Leitão et al. História e memória. 5. ed. Campinas, SP: Editora da Unicamp: 2003.

LIMA, Cecília Neves. A formação de professores no Distrito Federal: os cursos da Divisão de Aperfeiçoamento do Magistério (DAM/CBPE/INEP) nos anos de 1955 a 1964. 2008. 146 f. Dissertação (Mestrado em Educação). Centro de Ciências Humanas e Sociais. Universidade Federal do Estado do Rio de Janeiro. Rio de Janeiro, 2008.

LÔBO, Olinda Rocha. A professorinha do grupo escolar. Entrevista ao Correio Braziliense. Conceição Freitas, em Brasília, em 07 de abril de 2010. Número 45.

LOPES, Eliane Marta Teixeira; GALVÃO, Ana Maria de Oliveira. História da Educação. Rio de Janeiro: DP\&A, 2001.

LOURENÇO FILHO, Manoel Bergström. A formação de professores: da Escola Normal à Escola de Educação /Manoel Bergström Lourenço Filho. Organização: Ruy Lourenço Filho. Brasília: Instituto Nacional de Estudos e Pesquisas Educacionais, 2001.

MACEDO, Roberta de Barros do Rego. As Orientações Pedagógica e Psicopedagógica no Contexto da Escola de Demonstração do Inep no Rio de Janeiro, nas Décadas de 1950/1960. 2007. 113 f. Dissertação (Mestrado em Educação) - Pontifícia Universidade Católica, Rio de Janeiro, 2007.

MEC- Ministério de Educação e Cultura. Relatório Quinquenal: 1956-1960. Brasília, 1960.

MEKSENAS, Paulo. Pesquisa social e ação pedagógica conceitos, métodos e práticas. São Paulo: Edições Loyola, 2002. 
MEMORIAL JK. As razões da mudança da capital. http://www.memorialjk.com.br/bsb/pgs/mudancas.htm. em 29/10/2014. Acesso em: 29 out. 2014.

MENDONÇA, Ana Waleska Pollo. Por uma política de formação do magistério nacional: O Inep/MEC dos anos 1950/1960; (org.) Brasília: Inep, 2008.

. Prefácio In: PEREIRA, Eva Waisros et. al. Nas asas de Brasília: memórias de uma utopia educativa (1956-1964). Brasília: Universidade de Brasília, 2011.

NOVACAP. Relatório das Observações feitas na Escola Experimental do CRINEP, em Salvador, Bahia, 30 de setembro de 1959a.

NOVACAP- COMPANHIA URBANIZADORA DA NOVA CAPITAL DO BRASIL. A educação primária em Brasília. Brasília, dezembro de 1959 b.

NUNES, Clarisse. Um olhar sobre Anísio. In: SEMINÁRIO "Um olhar sobre Anísio". Mesa Redonda Política Educacional, Rio de Janeiro, set. 1999. Rio de Janeiro, UFRJ/CFCH /PACC, Fundação Anísio Teixeira, 1999.

, Centro Educacional Carneiro Ribeiro: concepção e realização de uma experiência de educação integral no Brasil. Em Aberto, Brasília, v. 22, n. 80, p. 121-134, abr. 2009.

OLIVEIRA, Lúcia Lippi. O Brasil de JK- Brasília, a meta síntese. CPDOC/ FGV. Centro de Pesquisa e Documentação de História Contemporânea do Brasil, 2012.

PAIVA, Edil Vasconcelos; PAIXÃO, Léa Pinheiro. PABAEE (1956-1964) - A americanização do ensino elementar no Brasil? Niterói: Editora Federal Fluminense, 2002.

PEREIRA, Eva Waisros; ROCHA, Lúcia Maria da França. Anísio Teixeira e o plano de educação de Brasília. In: MENDONÇA, Ana Waleska; XAVIER, Libânea Nacif. (orgs.). Por uma política de formação do magistério nacional: o INEP/MEC dos anos 1950/1960. Brasília, 2008.

Escola Parque de Brasília: uma experiência de educação integral. In: Nas asas de Brasília: memórias de uma utopia educativa (1956-1964). Brasília: Universidade de Brasília, 2011.

PEREIRA, Eva Waisros; ROCHA, Lúcia Maria da França. Anísio Teixeira e o plano de educação de Brasília. In: PEREIRA, Eva Waisros et. al. Nas asas de Brasília: memórias de uma utopia educativa (1956-1964). Brasília: Universidade de Brasília, 2011.

PEREIRA, Eva Waisros; CARVALHO, Pedro Mesquita de. Resistência, contradições e impasses na concretização do plano de Anísio Teixeira. In: PEREIRA, Eva Waisros et. al. Nas asas de Brasília: memórias de uma utopia educativa (1956-1964). Brasília: Universidade de Brasília, 2011. 
PEREIRA, Eva Waisros; HENRIQUES, Cinira Maria Nóbrega. Escola Júlia Kubitschek - A primeira escola pública do Distrito Federal. In: PEREIRA, Eva Waisros et. al. Nas asas de Brasília: memórias de uma utopia educativa (1956-1964). Brasília: Universidade de Brasília, 2011.

PEREIRA, Eva Waisros. Fontes documentais para a história da educação de Brasília. III EHECO - Catalão-GO. Agosto de 2015.

PIMENTEL, Adriana. O método da análise documental: seu uso numa pesquisa historiográfica. Cadernos de Pesquisa, n. 114, p. 179-195, novembro/ 2001.

PINTO, Karina Pereira. Por uma nova cultura pedagógica: Prática de Ensino como eixo da formação de professores primários do Instituto de Educação do Rio de Janeiro (1932-1937). 2006. 390 f. Tese (Doutorado em Educação: História, Política e Sociedade). Pontifícia Universidade Católica de São Paulo. 2006.

RAPPAPORT, Clara Regina et. al. Psicologia do desenvolvimento. São Paulo: EPU, 1981.

REVISTA BRASÍLIA, Ano 1, n. 10, out/ 1957.

ROTTHEN, José Carlos. O Inep com seus 70 anos: um senhor maduro em constante busca de sua identidade. In O Inep na visão de seus pesquisadores. Brasília, 2008.

SAVIANI, Demerval. História das ideias pedagógicas no Brasil. 2 ed. rev. e ampl. Campinas, São Paulo: Autores Associados, 2008.

- Formação de professores: aspectos históricos e teóricos do problema no contexto brasileiro. Revista Brasileira de Educação. V. 14, n. 40, jan./abr, 2009.

O Inep, o diagnóstico da educação brasileira e a Rbep. Revista Brasileira de Estudos Pedagógicos. Brasília, v. 93, n. 234, (número especial), p. 291-322, mai/ago. 2012.

SILVA, Ernesto. História de Brasília: um sonho, uma esperança, uma realidade. 3. ed. Brasília, DF: Linha Gráfica, 1997.

SILVA, Renata Souza. Os professores pioneiros do Distrito Federal: história e memória da profissão docente. 2010. 104 f. Dissertação (Mestrado). Faculdade de Educação, Universidade de Brasília. Brasília, 2010.

STRANG, Bernadete de Lourdes Streisky; BATTINI, Okçana, NISHHIKAWA, Reinaldo Benedito. A Escola Guatemala e as memórias de uma experiência educacional de vanguarda. Revista Diálogo Educacional. Curitiba, v. 13, n. 40, set/dez. 2013.

TEIXEIRA, Anísio. Estudo sobre o projeto de Lei das Diretrizes e Bases da Educação Nacional. Revista Brasileira de Estudos Pedagógicos. Rio de Janeiro, v. 18, n. 48, out./dez. 1952. 
Educação não é privilégio. Rio de Janeiro, 1957.

. Curso, estágio e seminário para formação do professor. Entrevista ao Jornal do Comércio. Rio de Janeiro, 20 abr. 1958.

Filosofia e educação. Educação e Ciências Sociais. Ano IV, vol. 6, n. 12. 1959.

- Plano de Construções Escolares de Brasília. Revista Brasileira de estudos pedagógicos, n. 81, volume 35. jan./mar 1961.

Uma experiência de educação primária integral no Brasil. Revista Brasileira de Estudos Pedagógicos. Rio de Janeiro, v. 38, n. 87, jul./set. 1962.

Fazer de Brasília um modêlo para a educação no País. Entrevista ao Correio Braziliense. Brasília, 21 jun. 1963.

A Escola Parque da Bahia. Revista Brasileira de Estudos Pedagógicos. Rio de Janeiro, v. 47, n. 106, p. 246-253, abr./jun. 1967.

O problema de formação do magistério, 2. ed. Revista Brasileira de Estudos Pedagógicos, Brasília, v. 82, n. 200/201/202, p. 199-206, jan./dez. 2001.

VIEIRA, Maria do Pilar de Araújo; Peixoto, Maria do Rosário da Cunha; Khoury, Yara Maria Aun. A pesquisa em História. 4. ed. Ática: São Paulo, 2002.

XAVIER, Libânea Nacif. Qualificação de professores em três campanhas do Ministério da Educação no decênio 1950-1960. In: MENDONÇA, Ana Waleska; XAVIER, Libânea Nacif. (orgs.). Por uma política de formação do magistério nacional: o INEP/MEC dos anos 1950/1960. Brasília, 2008.

YIN, Robert K. Estudo de caso, planejamento e métodos. trad. Ana Thorell. 4. ed. Porto Alegre: Bookman, 2010.

\section{FONTES PRIMÁRIAS}

COSTA, Elzy Lobo. Currículo s/n. Pertence ao Dossiê da profa. Elzy Lobo Costa. Arquivos do acervo do grupo de pesquisa do projeto "Educação básica pública do Distrito Federal (1956-1964): origens de um projeto inovador” UnB. Distrito Federal. s/d.

Elzy Lobo. Caderno de anotações. Arquivos do acervo do grupo de pesquisa do projeto "Educação básica pública do Distrito Federal (1956-1964): origens de um projeto inovador" UnB. Distrito Federal. s/d.

INEP. Dados extraídos de fichas: Número de cursistas, em 1963, por Estado e Território. Arquivos do INEP - Distrito Federal. 1963. 
MEC. Relatório dos trabalhos realizados pela Coordenação dos Cursos do INEP de 1956 a 1960. Arquivos do INEP - Distrito Federal. 1960.

NOVACAP. Relatório do estágio na escola de aplicação do Crinep, Salvador/Bahia. Em 1959.

SOYER, Santa Alves. “Trabalho de Estágio - Relatório das Observações nas Escolas do CRINEP - Salvador- Bahia”, 1968.

\section{ENTREVISTAS}

ANDRADE, Amábile Gomes, Entrevista concedida ao professor Erasto Fortes de Mendonça no âmbito da pesquisa "Educação básica pública do Distrito Federal (1956-1964): origens de um projeto inovador” UnB/ FE, em 05/09/2002. Brasília, DF.

BESSA, Maria do Rosário Ávila de. Entrevista concedida aos professores Francisco Heitor M. Souza, Cinira Maria Nóbrega, Maria Alexandra e Eva Waisros Pereira, no âmbito da pesquisa "Educação básica pública do Distrito Federal (1956-1964): origens de um projeto inovador" UnB/ FE, 09 de julho de 2008. Brasília, DF.

BRANDÃO, Maria de Lourdes Cruvinel. Entrevista concedida aos professores Francisco Heitor M. Souza Cinira Maria Nóbrega e Eva Waisros Pereira no âmbito da pesquisa "Educação básica pública do Distrito Federal (1956-1964): origens de um projeto inovador" UnB/ FE, em 05 de junho de 2008. Brasília, DF.

CANÊDO, Maria dos Reis. Entrevista concedida aos professores Erasto Fortes de Mendonça e Cinira Maria Nóbrega Henriques no âmbito da pesquisa "Educação básica pública do Distrito Federal (1956-1964): origens de um projeto inovador" UnB/ FE, em 30 de outubro de 2001, Brasília, DF.

CINTRA, Maria Marta. Entrevista concedida aos professores Eva Waisros Pereira, Cinira Maria Nóbrega e Francisco Heitor M. de Souza no âmbito da pesquisa "Educação básica pública do Distrito Federal (1956-1964): origens de um projeto inovador”, em 22 de setembro de 2006, UnB/ FE, Brasília, DF.

LÔBO, Olinda da Rocha. Entrevista concedida aos professores Wanda Cozetti e Ronaldo Mesquita no âmbito da pesquisa "Educação básica pública do Distrito Federal (1956-1964): origens de um projeto inovador”, em 08 de março de 2001, UnB/ FE, Brasília, DF.

Entrevista concedida aos professores Wanda Cozetti e Ronaldo Mesquita no âmbito da pesquisa "Educação básica pública do Distrito Federal (1956-1964): origens de um projeto inovador", (fita 1-A). UnB/ FE, em 08 de março de 2001, Brasília, DF. 
Entrevista concedida aos professores Wanda Cozetti e Ronaldo Mesquita no âmbito da pesquisa "Educação básica pública do Distrito Federal (1956-1964): origens de um projeto inovador", (fita 1-B), UnB/ FE, em 08 de março de 2001, Brasília, DF.

Entrevista concedida aos professores Wanda Cozetti e Ronaldo Mesquita no âmbito da pesquisa "Educação básica pública do Distrito Federal (1956-1964): origens de um projeto inovador" UnB/ FE, em 08 de março de 2001, Brasília, DF. (fita 2-A).

Entrevista concedida aos professores Wanda Cozetti e Ronaldo Mesquita no âmbito da pesquisa "Educação básica pública do Distrito Federal (1956-1964): origens de um projeto inovador" UnB/ FE, em 08 de março de 2001, Brasília, DF. (fita 2-B).

Entrevista concedida aos professores Wanda Cozetti e Ronaldo Mesquita no âmbito da pesquisa "Educação básica pública do Distrito Federal (1956-1964): origens de um projeto inovador" UnB/ FE, em 08 de março de 2001, Brasília, DF. (fita 3-A).

Entrevista concedida aos professores Wanda Cozetti e Ronaldo Mesquita no âmbito da pesquisa "Educação básica pública do Distrito Federal (1956-1964): origens de um projeto inovador" UnB/ FE, em 08 de março de 2001, Brasília, DF. (fita 3-B).

MORICI, Maria das Neves Costa. Entrevista concedida aos professores Erasto Fortes de Mendonça e Cinira Maria Nóbrega Henriques no âmbito da pesquisa "Educação básica pública do Distrito Federal (1956-1964): origens de um projeto inovador”. UnB/ FE, em 29 de setembro de 2001. Brasília DF. (fita 1-A).

MORRONE, Ivonilde de Faria. Entrevista concedida as professoras Vera Margarida Lessa Catalão e Wanda Cozetti Marinho no âmbito da pesquisa "Educação básica pública do Distrito Federal (1956-1964): origens de um projeto inovador” UnB/ FE, em 29 de agosto de 1990. Brasília DF.

Entrevista concedida as professora Eva Waisros Pereira, Alexandra Militão e Daylane Soares Diniz no âmbito da pesquisa "Educação básica pública do Distrito Federal (1956-1964): origens de um projeto inovador" UnB/ FE, em 22 de Maio de 2012. Brasília DF.

OBLIZINER Dalva Batista. Entrevista concedida à professora Eva Waisros Pereira, no âmbito da pesquisa "Educação básica pública do Distrito Federal (1956-1964): origens de um projeto inovador", participação de alunos da Faculdade de Educação/UnB. UnB/ FE, em 24 de junho de 2003. Brasília, DF.

SILVA, Ernesto. Entrevista concedida as professoras Eva Waisros Pereira e Cinira Maria Nóbrega, no âmbito da pesquisa "Educação básica pública do Distrito Federal (1956-1964): origens de um projeto inovador” UnB/ FE, em 30 de junho de 2007. Brasília, DF.

SOYER, Santa Alves Soyer. Entrevista concedida as professoras Wanda Cozetti Marinho e Jeanina Daher, no âmbito da pesquisa "Educação básica pública do Distrito Federal (19561964): origens de um projeto inovador” UnB/ FE, em 24/01/1990. Brasília, DF. 
TROIS, Stella dos Cherubins Guimarães. Entrevista concedida as professoras Wanda Cozetti Marinho e Jeanina Daher, com participação de alunos da Faculdade de Educação/UnB no âmbito da pesquisa "Educação básica pública do Distrito Federal (1956-1964): origens de um projeto inovador" UnB/ FE, em 18 de setembro de 1990. Brasília, DF.

VIEIRA, Alita. Entrevista concedida as professoras Vera Lessa Catalão, Jeanina Daher e Wanda Cozetti Marinho, no âmbito da pesquisa "Educação básica pública do Distrito Federal (1956-1964): origens de um projeto inovador” UnB/ FE, (fita 1-A), 1990. Brasília, DF

Entrevista concedida as professoras Vera Lessa Catalão, Jeanina Daher e Wanda Cozetti Marinho, no âmbito da pesquisa "Educação básica pública do Distrito Federal (19561964): origens de um projeto inovador” UnB/ FE, (fita 1-B), 1990. Brasília, DF.

Entrevista concedida as professoras Vera Lessa Catalão, Jeanina Daher e Wanda Cozetti Marinho, no âmbito da pesquisa "Educação básica pública do Distrito Federal (19561964): origens de um projeto inovador” UnB/ FE, (fita 2-A), 1990. Brasília, DF. 


\section{ANEXO A - RELAÇÃO DAS PRIMEIRAS PROFESSORAS DA ESCOLA JÚLIA KUBITSCHEK}

Quadro 4 - Relação nominal das primeiras Professoras da Escola Júlia Kubitschek

\begin{tabular}{|c|l|l|}
\hline & \multicolumn{1}{|c|}{ Nome } & Função \\
\hline 1 & Santa Alves Soyer & Diretora \\
\hline 2 & Stella dos Cherubins G.Trois & Sub-diretora \\
\hline 3 & Ana Pereira Leal e Costa & Professora \\
\hline 4 & Antônia Pasczkoski & Professora \\
\hline 5 & Antonieta Silva & Professora \\
\hline 6 & Antonieta Viana Lôbo Pereira & Professora \\
\hline 7 & Aroenes Jacinto Pinheiro & Professora \\
\hline 8 & Delcy Aguiar & Professora \\
\hline 9 & Dinalva Maria Guimarães & Professora \\
\hline 10 & Dinhai Batista de Brito & Professora \\
\hline 11 & Ivany Ehrhart & Professora \\
\hline 12 & Maria Amélia Caltabiano Neves & Professora \\
\hline 13 & Maria das Neves Morici & Professora \\
\hline 14 & Maria de Lourdes Cruvinel Brandão & Professora \\
\hline 15 & Maria de Lourdes M Santos & Professora \\
\hline 16 & Maria Helena de Lana Tôrres & Professora \\
\hline 17 & Maria HelenaFúrio & Profora \\
\hline 18 & Maria Helena Parreira & Prora \\
\hline 19 & Milza Papalamdrópulos & Pra \\
\hline 20 & Raquel Dourado de Castro & Profora \\
\hline 21 & Olinda Rocha Lôbo & Profora \\
\hline 22 & Orbela de Souza Lôbo & Profora \\
\hline
\end{tabular}

Fonte: Novacap. A Educação Primária em Brasília. 1959. 


\section{ANEXO B - RELAÇÃO DE PROFESSORES CONTRATADOS PELA NOVACAP 1957-1959}

Quadro 5 - Professores contratados pela Novacap -1957 A 1959

\begin{tabular}{|c|c|}
\hline 1 & Alfa Aguiar \\
\hline 2 & Allia Félício Tobias \\
\hline$\underline{3}$ & Amábile de Andrade Gomes \\
\hline 4 & Amaury de Almeida \\
\hline 5 & Amélia Alexandre Costa \\
\hline 6 & Anísia dos Santos da Rocha Cravo \\
\hline 7 & Antônia Paczkoski \\
\hline 8 & Antonieta Silva \\
\hline 9 & Antonieta Viana Lobo Pereira \\
\hline 10 & Aroenes Jacinto Pinheiro \\
\hline 11 & Henrique Teixeira Tam \\
\hline 12 & Irmã Catarina Colativitti \\
\hline 13 & Conceição Guimarães Campos \\
\hline 14 & Dalva Ribeiro Prado \\
\hline 15 & Delcy Aguiar \\
\hline 16 & Delza Guimarães \\
\hline 17 & Dinhai Batista de Brito \\
\hline 18 & Edna Baker \\
\hline 19 & Elisa Clepf \\
\hline 20 & Elrese M. Penna Breschianini \\
\hline 21 & Elza Alves Cunha \\
\hline 22 & Elza Alves Kipgen \\
\hline 23 & Geny Ramos Vieira \\
\hline 24 & Helena Lopes de Melo \\
\hline 25 & Hilda Teles de Faria \\
\hline 26 & Ilcey Miriam de Mello \\
\hline 27 & Itala da Silva Conde \\
\hline 28 & Julieta Gonçalves dos Reis \\
\hline 29 & Lêda Guimarães \\
\hline
\end{tabular}




\begin{tabular}{|c|c|}
\hline 30 & Leocádia Paradela Toscano \\
\hline 30 & Lígia de Oliveira \\
\hline 31 & Lúcia Darú Cicslak \\
\hline 32 & Maria Amélia Caltabiano Neves \\
\hline 33 & Maria da Glória Freitas Quintela \\
\hline 34 & Maria Helena Aparecida Paiva \\
\hline 35 & Maria Helena Fúrio \\
\hline 36 & Maria Helena de Lana Torres \\
\hline 37 & Maria Isaura de Albuquerque e Silva \\
\hline 38 & Maria de Lourdes Souza Goulart \\
\hline 39 & Maria das Neves Costa Morici \\
\hline 40 & Maria Reis Canêdo \\
\hline 41 & Maria do S. B. Lira de Freitas \\
\hline 42 & Maria Tereza de Almeida Falcão \\
\hline 43 & Mireta de Melo Andrade \\
\hline 44 & Natanry Ludovico Lacerda Osório \\
\hline 45 & Neusa Maria Costa \\
\hline 46 & Olinda da Rocha Lôbo \\
\hline 47 & Rachel de Castro Dourado \\
\hline 48 & Irmã Maria Olga do Nascimento Monteiro \\
\hline 49 & Stela Magalhaes Paiva \\
\hline 50 & Cremilda de Araújo \\
\hline 51 & Irmã Terezinha de Jesus J. Prudente \\
\hline 52 & Lola Azra Barenechea \\
\hline 53 & Zoé Guimarães Pereziz \\
\hline
\end{tabular}

Fontes: Revista Brasília n ${ }^{\circ}$ 4- NOVACAP, abril 1960, p. 5 e 6;

Revista Brasília no 40- NOVACAP, 21/04/1960, p. 23 e 24. 


\section{ANEXO C - DOCUMENTO CASEB}

\section{CARTA CIRCULAR - PROFESSORES PRIMÁRIOS - CASEB}

Para a seleção de professores foram elaboradas duas cartas circulares, acompanhadas, cada uma, de um formulário.

Ainda no Boletim da CASEB, organizado pelo Professor Roberto Gomes Leobons, encontram-se as referidas cartas:

\section{"MEC - COMISSÃO DE ADMINISTRAÇÃO DO SISTEMA EDUCACIONAL DE BRASILIA (CASEB)}

Rio de Janeiro, 5 de janeiro de 1960

Senhor Professor:

Para a organização do sistema educadional de grau elementar e médio em Brasília, está o Ministério da Educação e Cultura selecionando professores, conforme as seguintes condições gerais:

1. A escolha de professores destinados a escolas primárias e jardins da infância, será baseada nos elementos fornecidos pelo formulário anexo, no resultado de prova escrita e de entrevistas com o candidato.

2. Os professores escolhidos firmarão contratos de prestação de serviços regidos pela legislação trabalhista e perceberão salário mensal entre $\mathrm{Cr} \$ 15.000,00$ e $25.000,00$.

3. Os professores selecionados receberão passagem para si e sua família, ajuda de custo para sua instalação em Brasília e terão direito a residência mediante pagamento de aluguel accessível. O ensino primário e médio serão gratuitos aos seus filhos.

4. Os professores estarão obrigados a um mínimo de seis horas diárias de trabalho, o qual consistirá em ensino, preparo das aulas e de material didático na própria escola, orientação do estudo dirigido, participação em seminários, atividades extra-classe e outras, decorrentes da função docente.

Maiores esclarecimentos serão prestados por ocasião das entrevistas com o candidato.

Dando, por esta forma, aos professores capazes de todo o País uma oportunidade de virem a servir à causa da educação na nova $\mathrm{Ca}$ pital, solicito-Ihe preencher o incluso formulário e devolvê-lo ao endereço abaixo indicado até 25 de janeiro de 1960, ficando certo de que as informações nele prestadas terão caráter confidencial. Os formulários dos candidatos não aproveitados Ihes serão restituídos.

a) Armando Hildebrand Diretor Executivo 
Remeter o formulário para:

Comissão de Administração do Sistema

Educacional de Brasília

At./Armando Hildebrand

Ministério da Educação e Cultura

Rua da Imprensa, 16 - 12? andar - sala 1210

Rio de Janeiro - D.F."

\section{MEC - COMISSĀO DE ADMINISTRAÇĀO DO SISTEMA EDUCACIONAL DE BRASILIAA}

Formulário para seleção de professores de curso primário para Brasília Nome

Endereço - Rua
Bairo
Telefone__ Estado
Cidade_Estado civil
Data do nascimento___ _ _ Estado

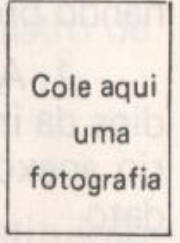

Dados so- Nome

bre o Profissão cônjuge Atividade que exerce

Filhos e outros dependentes:

\begin{tabular}{l|l|l|l|l}
\hline Nome & Sexo & $\begin{array}{c}\text { Ida- } \\
\text { de }\end{array}$ & $\begin{array}{l}\text { Parentesco ou } \\
\text { situação de } \\
\text { dependência }\end{array}$ & $\begin{array}{c}\text { Atividades } \\
\text { ou estudos } \\
\text { que realiza }\end{array}$ \\
\hline 1. & & & & \\
\hline 3. & & & & \\
\hline 5. & & & & \\
\hline 6. & & & & \\
\hline & & & & \\
\hline
\end{tabular}

Indique pelos números 1,2 e 3 , na ordem de sua preferência, as atividades que deseja exercer:
( ) professor de classe
( ) professor bibliotecário
( ) professor de jardim da infância
( ) professor de educação física e recreação
( ) professor de canto orfeônico professor de atividades ex- tra-classe
professor de artes aplicadas Data do nascimento 1 
2. Nome

Cargo.

Endereço

3. Nome

Cargo

Endereço

Resuma sua formação escolar e profissional e as experiências anteriores no magistério, indicando, também, as razões que o levam a candidatar-se à função docente em Brasília.

de

de 1960 